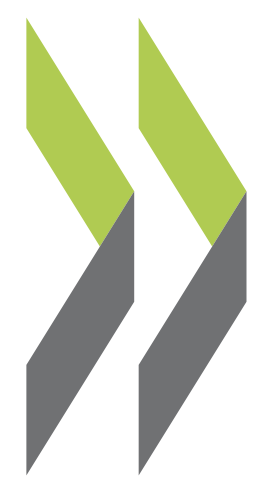

OECD Trade and Environment Working Papers 2013/01

\title{
Domestic Incentive \\ Measures for Renewable Energy With Possible Trade Implications
}

\section{Heymi Bahar,} Jagoda Egeland, Ronald Steenblik 


\section{OECD TRADE AND ENVIRONMENT PAPERS}

The OECD Trade and Environment Working Paper series is designed to make available to a wide readership selected studies by OECD staff or by outside consultants.

This document has been declassified on the responsibility of the Joint Working Party on Trade and Environment under the OECD reference number COM/TAD/ENV/JWPTE(2011)46/FINAL.

Comments on the papers in this series are welcome and should be sent to env.contact@oecd.org or tad.contact@oecd.org.

This document and any map included herein are without prejudice to the status of or sovereignty over any territory, to the delimitation of international frontiers and boundaries, and to the name of any territory, city or area.

The statistical data for Israel are supplied by and under the responsibility of the relevant Israeli authorities. The use of such data by the OECD is without prejudice to the status of the Golan Heights, East Jerusalem and Israeli settlements in the West Bank under the terms of international law.

\section{OECD TRADE AND ENVIRONMENT PAPERS}

are published on the OECD's trade (www.oecd.org/trade) and environment (www.oecd.org/environment) web pages, as well as on the OECD iLibrary web pages (www.oecd-ilibrary.org)

Ce document est également disponible en français sur le site Internet de l'OCDE à l'adresse URL suivante : www.oecd.org/trade/envtrade

You can copy, download or print OECD content for your own use, and you can include excerpts from OECD publications, databases and multimedia products in your own documents, presentations, blogs, websites and teaching materials, provided that suitable acknowledgment of OECD as source and copyright owner is given. All requests for commercial use and translation rights should be submitted to rights@oecd.org. 


\title{
Abstract \\ Domestic Incentive Measures for Renewable Energy With Possible Trade Implications
}

\author{
Heymi Bahar, Jagoda Egeland, and Ronald Steenblik
}

In recent years the manufacturing of renewable-energy technologies has become truly global. The associated rise in international investment and trade in goods and services related to renewable energy has been rapid, but it has not always been smooth. Already there have been challenges at the WTO, and the unilateral imposition of countervailing and anti-dumping duties, in response to some countries' policies on the grounds that they distort trade. Against this background, this paper surveys, through the lenses of market-pull and technology-push policies, the numerous domestic incentives used by governments to promote renewable energy, focusing on those that might have implications for trade — both those that are likely to increase opportunities for trade and those that may be inhibiting imports or promoting exports. Many OECD countries, and an increasing number of non-OECD countries, have established national targets for renewable energy. To help boost the rate of penetration of renewable energy in their economies, most of the same countries are providing additional incentives. Market-pull incentives for the deployment of renewable-energy-based electricity generating plants include quota systems, usually administrated through "green" certificates, and fixed per kilowatt-hour feed-in tariffs and premiums. Renewable fuels for transport are typically promoted by governments through obliging fuel suppliers to mix ethanol or biodiesel with their corresponding petroleum-derived fuels. Frequently, renewable fuels for transport also benefit from exemptions, or reductions in, fuel-excise taxes, and in a few countries from production bounties. Many national and sub-national governments also support capital formation in these industries with grants, subsidised loans, loan guarantees, or a combination of instruments. In some jurisdictions, access to government support schemes have been made conditional upon meeting certain minimum levels of domestic content. Such domestic-content requirements are highly controversial because of their direct effects on trade. These effects, and the effects of other policies in combination and in isolation, are examined through a graphical analysis of generic policies, using a simplified stylised representation of the relevant markets. The basic message is that while many domestic incentives are both increasing the supply of renewable energy and facilitating trade in associated technologies and renewable fuels, some - especially those combined with border protection or domestic-content requirements - are likely reducing export opportunities for foreign suppliers, and raising domestic prices for renewable energy as a consequence.

JEL Classification: F18, H23, L98, O38, Q42, Q56, Q58.

Keywords: Trade, environment, environmental subsidies, biofuels, bioenergy, renewable energy. 


\section{Acknowledgements}

This paper was written by Heymi Bahar, Jagoda Egeland, and Ronald Steenblik of the Environment Policies Division of the OECD Trade and Agriculture Directorate. The authors thank Caroline Gomes Nogueira for additional research assistance, and Michèle Patterson and Theresa Poincet for their help in preparing the document for publication. The authors appreciate the ideas and comments provided by Jehan Sauvage of the OECD, Anselm Eisentraut and Michael Waldron of the International Energy Agency, and Pierre Tardieu of the European Wind Energy Association. And the authors thank Véronique de Saint Martin and Caroline Gomes Nogueira for their help with the French translation of the document.

This paper was discussed by the Joint Working Party on Trade and Environment (JWPTE), which agreed to declassify the document under a written procedure. The authors are grateful to the delegates for their many comments and suggestions. Any errors or omissions are the sole responsibility of the authors. 


\section{Table of contents}

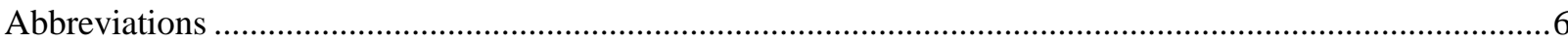

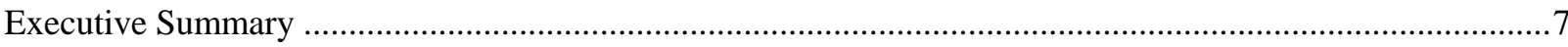

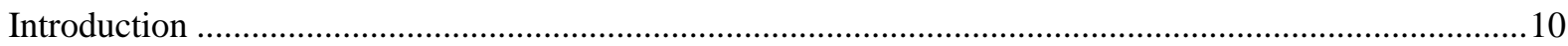

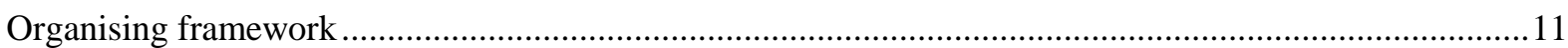

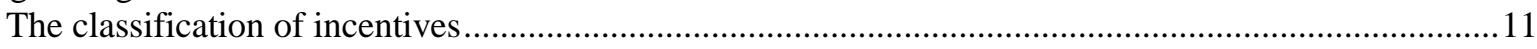

Government incentives from a dynamic perspective: The innovation imperative..............................14

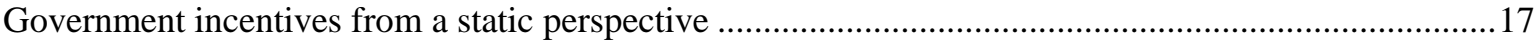

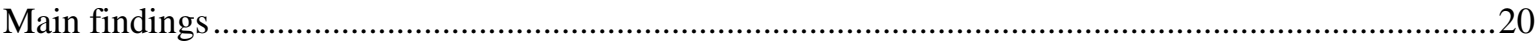

Annex 1. A survey of policies supporting renewable energy and biofuels ...............................................24

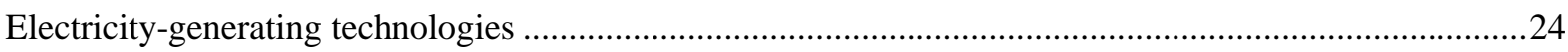

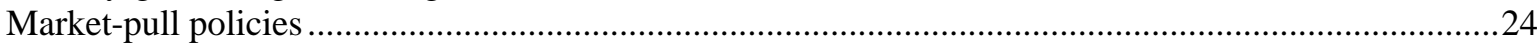

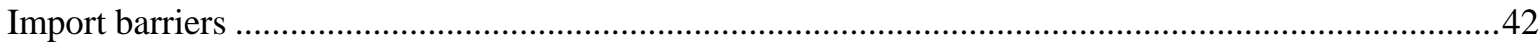

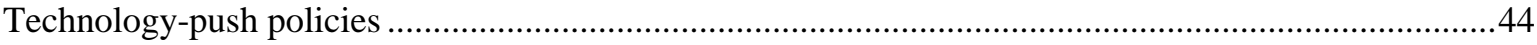

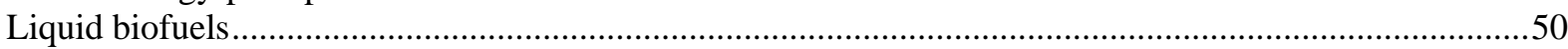

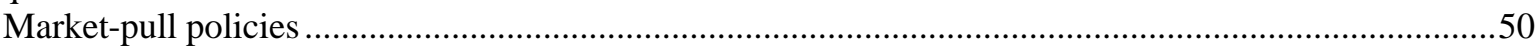

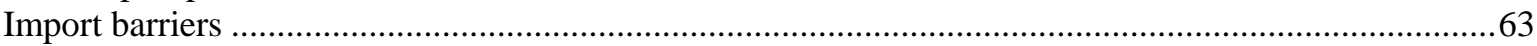

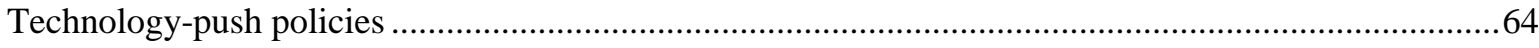

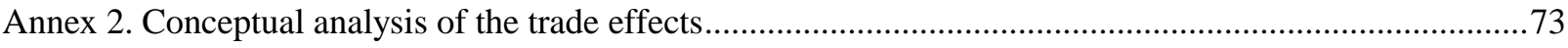

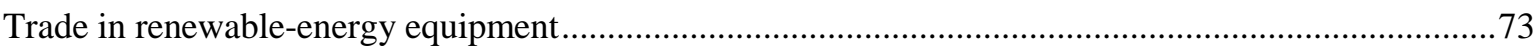

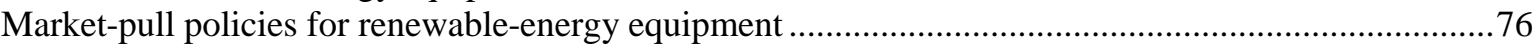

Market-pull policies in combination with import tariffs or domestic-content requirements

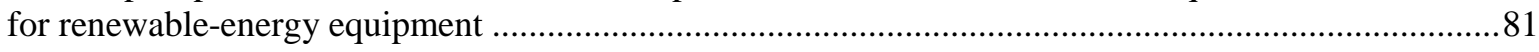

Technology-push incentives for renewable-energy technologies .............................................. 83

Incentives for investment in domestic production of biofuels ............................................... 86

Long-term impacts of policies supporting renewable energy …..................................................8

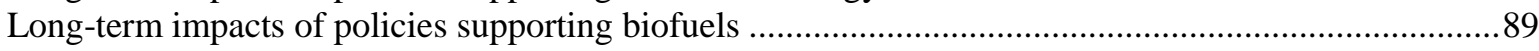

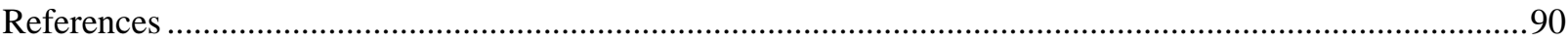

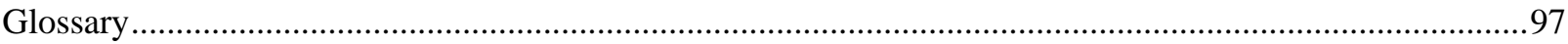

\section{Tables}

Table A.1. EU-27 National Renewable Energy Targets for 2020 as stipulated by the Directive 2009/28/EC

Table A.2. Renewable-Energy Targets in Latin America and the Caribbean ......................................26

Table A.3. Indicative feed-in tariff levels for new renewable-electricity plants in OECD countries ........31

Table A.4. Feed-in tariff levels in selected non-OECD countries.........................................................33

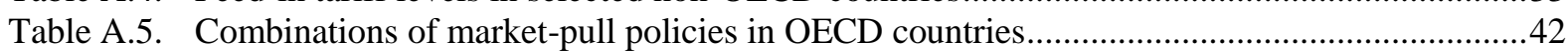

Table A.6. Average import tariffs of major importers on selected renewable-energy technologies and parts, as of January 20131 
Table A.7. Tax preferences on retail sales of ethanol and biodiesel in OECD and non-OECD EU countries

Table A.8. Minimum mandated volumes or blend ratios for ethanol and biodiesel in OECD countries, as of end July 2012

Table A.9. Mandated volumes or blend ratios for ethanol and biodiesel in nonOECD countries, as of end 2012 .

Table A.10. Average import tariffs of major importers on liquid biofuels, 2012

Table A.11. Production-related incentives for ethanol and biodiesel in OECD countries as of early 2013

\section{Figures}

Figure 1. Matrix of transfers benefitting consumption and consumer-produced energy, with examples of specific support policies.

Figure 2. Matrix of transfers benefitting production, with examples of specific support policies ..........13

Figure 3. Stylized stages of government intervention to support new technologies..............................15

Figure 4. Static view of points of government support in the electricity generation value chain........... 19

Figure 5. Static view of points of government support in the biofuels value chain...............................19

Figure 6. Trade in renewable-energy equipment: Small country ........................................................ 74

Figure 7. Trade in renewable-energy equipment: Large country .....................................................75

Figure 8. Export supply curve of Country A as a close-up of the export supply curve of Country B ....75

Figure 9. Impact of disincentives to non-renewable energy on the market for energy ...........................78

Figure 10. Impact of renewable-energy incentives on the market for energy ........................................79

Figure 11. Impact of demand-pull policies on the market for renewable-energy equipment:

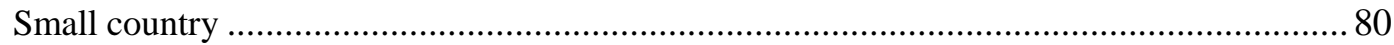

Figure 12. Impact of demand-pull policies on the market for renewable-energy equipment:

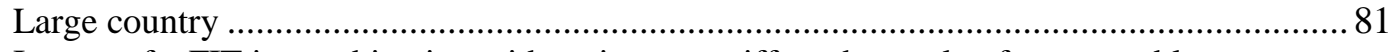

Figure 13. Impact of a FIT in combination with an import tariff on the market for renewable-energy

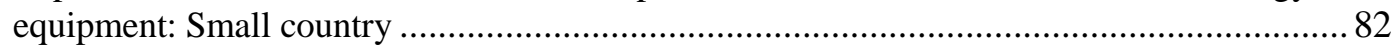

Figure 14. Impact of a FIT in combination with an import tariff on the market for renewable-energy

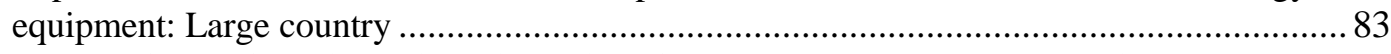

Figure 15. Impact of manufacturing-related incentives for renewable-energy technologies on the market for renewable-energy equipment: Small country .................................................... 85

Figure 16. Impact of manufacturing-related incentives for renewable-energy technologies on the market for renewable-energy equipment: Large country .................................................... 85

Figure 17. Impact of incentives for investment in domestic manufacturing for PV modules:

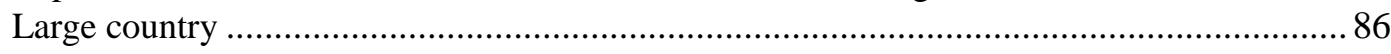

Figure 18. Impact of incentives for production of biofuels on the market for feedstock crops.................87

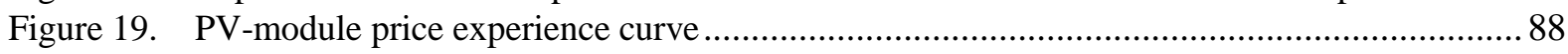

\section{Boxes}

Box 1. Pension-fund investment in green technologies ........................................... 17

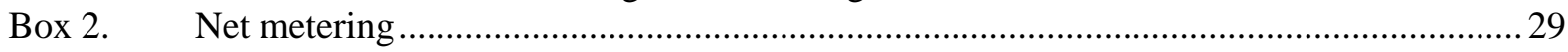

Box 3. Assumptions on the market for renewable energy and the market for electricity ............73

Box 4. Trade effects of feed-in tariffs versus quotas ................................................. 77

Box 5. Disincentives to non-renewable energy as a market-pull policy for renewable energy .... 78 


\begin{tabular}{|c|c|}
\hline .. & Not available \\
\hline $\begin{array}{l}\text { B5, B10, } \\
\text { etc. }\end{array}$ & $\begin{array}{l}\text { A blend of petroleum diesel and biodiesel containing the percentage of biodiesel indicated } \\
\text { by the number }\end{array}$ \\
\hline B100 & Pure biodiesel \\
\hline Billion & $10^{9}$ \\
\hline CCS & Carbon capture and storage \\
\hline $\mathrm{CHP}$ & Combined heat and power production \\
\hline DCR & Domestic-content requirement \\
\hline DOE & Department of Energy \\
\hline $\begin{array}{l}\text { E10, E85, } \\
\text { etc. }\end{array}$ & $\begin{array}{l}\text { A blend of petroleum gasoline and ethyl alcohol (ethanol) containing the percentage of } \\
\text { ethanol indicated by the number }\end{array}$ \\
\hline E100 & Pure ethanol \\
\hline ETS & Emissions Trading System (EU) or Emissions Trading Scheme (NZ) \\
\hline EU & European Union \\
\hline FIT & Feed-in tariff \\
\hline FQD & Fuel Quality Directive of the European Union \\
\hline gal & US gallon, equal to 3.7854 litres \\
\hline GHG & Greenhouse gas \\
\hline GW & Gigawatt $\left(1\right.$ Watt $\left.\times 10^{9}\right)$ \\
\hline HS & HS - Harmonised Commodity Description and Coding System \\
\hline IEA & International Energy Agency \\
\hline $\mathrm{kg}$ & Kilogramme (1 000 kg = 1 tonne $)$ \\
\hline $\mathrm{kg} \mathrm{CO}-\mathrm{eq}$ & Kilogramme of carbon-dioxide equivalent \\
\hline $\mathrm{kW}$ & Kilowatt $\left(1\right.$ Watt $\left.\times 10^{3}\right)$ \\
\hline $\mathrm{kWh}$ & Kilowatt-hour \\
\hline LCA & Life-cycle assessment \\
\hline million & $10^{6}$ \\
\hline MW & Megawatt (1 Watt x 106) \\
\hline MWh & Megawatt-hour \\
\hline n.a. & Not applicable \\
\hline n.c. & Not calculated \\
\hline $\mathrm{p}$ & Provisional \\
\hline ppm & Parts per million (by volume) \\
\hline PV & Photovoltaic \\
\hline R\&D & Research and development \\
\hline RD\&D & Research, development and demonstration \\
\hline REC & Renewable-energy certificate (or credit) \\
\hline RED & Renewable Energy Directive of the European Union \\
\hline RES & Renewable energy source \\
\hline ROW & Rest of the world \\
\hline RPS & Renewable-energy portfolio standard \\
\hline trillion & $10^{12}$ \\
\hline VAT & Value-added tax \\
\hline W & Watt (1 joule per second) \\
\hline
\end{tabular}




\section{Executive Summary}

Never has renewable energy been so popular. Although energy has been harvested from renewable sources - the sun, the wind, falling water, and heat from the earth - for hundreds of years, people are nowadays pinning their hopes on it with more urgency, particularly as a replacement for fossil fuels. This is both because fossil fuels yield carbon-dioxide - a greenhouse gas - when combusted, and because their supply is ultimately finite and, in the case of petroleum, geographically concentrated. For decades, governments, particularly in OECD countries, have been funding research and development in an effort to raise the efficiency of renewable energy, improve its reliability, and reduce its costs. More recently, policy makers have looked to the fast-increasing demand for goods and services associated with renewable-energy as an engine of economic growth. Both developed and emerging economies want to be at the forefront of developments in this new industry and have implemented policies aimed at increasing their capacity to develop, manufacture and service renewable-energy technologies.

Twenty years ago, the markets for most renewable-energy technologies and renewable fuels were small, and international trade was minimal. Since then, both the manufacturing of renewable-energy technologies, and their value chains, have become truly global. The associated rise in international investment and trade in goods and services related to renewable energy has been rapid, but it has not always been smooth. Already there have been challenges to some countries' policies on the grounds that they distort trade, and numerous observers have warned of increasing protectionism.

One of the main aims of the paper is to survey the policies currently in use to support renewable energy. ${ }^{1}$ The paper finds that many OECD countries, and an increasing number of non-OECD countries, have established national targets for renewable energy, typically to be achieved by 2020 but in some cases earlier. Some of these targets cover all forms of renewable energy, while others are specific to electricity or transport fuels, or both. To help boost the rate of penetration of renewable energy in their economies many of the same countries also use market-based instruments that favour electricity generated from renewable energy or renewable fuels. With respect to electricity, among the most common policies are special "feed-in" tariffs (FITs) - prices paid for electricity delivered to the electricity grid that either guarantee a fixed price for electricity sold to the electricity grid, usually for at least a decade, or a fixed premium per kilowatt-hour sold. Many national and sub-national governments also support the installation of renewable-energy-based electricity-generating facilities, typically with grants, subsidised loans, loan guarantees, or a combination of instruments. In the market for these facilities, domestic-content requirements are still the exception, but increasingly common; they are often applied by national or sub-national stateowned electric utilities. Preferences for local producers through government procurement also exist.

1. For this paper, the main policies surveyed are those relating to technologies that are used to generate electricity from renewable-energy sources (the sun, the wind, biomass, geothermal heat, falling or flowing water, waves, tides, and thermal differentials in the ocean) and liquid fuels from biomass. 
The main market-based instruments used to favour the consumption of renewable fuels for transport are exemptions from, or reductions in, fuel-excise taxes, and tax credits for companies that blend these fuels with petroleum fuels. These tax preferences apply only to renewable fuels used for surface transport, as bunker fuels used for international aviation are generally not taxed. A few, mainly sub-national, jurisdictions have linked implementation of their biofuel-content mandates with the development of in-state or in-province manufacturing capacity for the mandated fuel, and a few have tied eligibility for subsidies or tax preferences to the use of locally produced biomass feedstock.

Most OECD countries have extensive RD\&D programmes relating to renewable energy that they carry out either on their own or in co-operation with other countries. In 2011, they spent at least USD 4.1 billion on RD\&D related to renewable energy, according to the IEA. Developing and emerging countries typically provide incentives for foreign companies to set up production within their borders in order to encourage the transfer of technological knowhow. In addition, many governments, both in the OECD and among the larger emerging economies, provide assistance to companies that set up facilities to manufacture renewableenergy technologies or renewable fuels.

A second purpose of this paper is to analyse their possible implications for international trade. This is done with a conceptual, graphics-based model. All government interventions in the energy market ultimately affect trade, but some do so more directly than others. As the conceptual analysis shows, so-called "market-pull policies", which encourage the use of renewable-energy-based electricity or renewable fuels, will usually have a stimulating effect on trade, drawing in imports of goods and services to help meet the resulting increased demand. If implemented on a large scale, they may also increase the market price of renewable-energy equipment sold domestically, which may in consequence disincentivise both foreign and domestic producers from cost-cutting and product development. However, many countries have combined market-pull policies with other policies that are intended to ensure that a large share of their domestic demand is met by domestic suppliers. ${ }^{2}$ Such policy combinations may be particularly harmful for the domestic market through raising the domestic price of renewable-energy equipment and shielding domestic industries from taking part in the world competition, which usually drives down prices. Moreover, such combinations of policies are usually harmful for foreign companies that often cannot overcome barriers to entry introduced by these policies.

Technology-push policies, which seek to increase the supply of renewable-energy technologies and renewable fuels mostly focus on government support for research, development and demonstration (RD\&D) at early stages of innovation, and for product development and manufacturing at later stages. The trade effects of government support for $\mathrm{RD} \& \mathrm{D}$ depend on the details of the policies, how close the funded research or products are to commercial applications, and the generosity of the funding. In industries in which technology is constantly changing, $\mathrm{RD} \& \mathrm{D}$ can account for a major share of a manufacturing firm's costs. Government assistance - though clearly generating positive externalities through the diffusion of new knowledge - may nonetheless give recipient industries an advantage over their foreign competitors.

Government assistance to manufacturers is more clearly linked to trade outcomes, through exports or import substitution. ${ }^{3}$ The conceptual analysis shows that incentives for investment in manufacturing of renewable-energy equipment may lower the market price of renewable-

2. These policies include high tariffs on imports of renewable-energy technologies or fuels, domestic-content requirements, and government-procurement preferences.

3. The trade effects of investment incentives for domestic production of biofuels are also analysed, with particular focus on the knock-on effects on the market for feedstock crops. 
energy equipment sold in the domestic market, but usually not by the full amount of government support as some of the support will be captured by the producers in the form of super-normal profits. Whether and how trade is affected depends on the particulars of each scheme and the relevant market. In industries with extensive and dispersed global supply chains, support for a plant that assembles solar-photovoltaic modules, for example, may lead to increased imports of solar-PV cells and other components. By contrast, in industries that depend strongly on locally produced inputs, such as the manufacturing of biofuels from woody biomass, support for local manufacturing plants is likely to increase production from local suppliers. In other words, how much foreign firms can benefit from other countries' support for manufacturing will largely depend on the characteristics of the supply chain of the products in question. In both cases, a trade impact may occur through lower-than-otherwise imports of the finished product.

Ensuring that domestic-incentive policies are compatible with WTO subsidy rules is just as important for renewable-energy technologies and fuels as it is for other goods. Full transparency on domestic incentives, including through the WTO subsidy-notification process, would be helpful both in keeping trading partners informed and in promoting best practice in the use of domestic incentive measures. 


\section{Introduction}

The Intergovernmental Panel on Climate Change (IPCC) states that "renewable energy sources play a role in providing energy services in a sustainable manner, in particular, in mitigating climate change [...] and greenhouse gas (GHG) emissions associated with the provision of energy services are a major cause of climate change" (IPCC, 2011a). Considering that, worldwide, $81 \%$ of current primary energy comes from the combustion of fossil fuels (IEA, 2012) renewable energy technologies can play an important role in the mitigation of climate change. All around the globe, governments forge, and implement, various policies to promote the development and deployment of renewable-energy technologies through price and market mechanisms, subsidies, and regulations in an effort to address GHG emissions. At the beginning of 2011, more than 118 countries had some type of renewable-energy support policy in place, up from 55 countries in 2005 (REN21, 2011).

Incentives for renewable energy have created a fast-growing market for the generation of electricity and heat, and the production of liquid transport fuels. It is estimated that around half of the new electricity generating capacity installed globally during the two years 2008-09 was powered by renewable-energy sources. Globally, in 2010, new investments in renewable energy increased by 32\%, to USD 211 billion, from USD 160 billion in 2009 (UNEP, 2011). Investment in renewable-energy sources had grown fivefold in five years. Non-hydroelectric renewable power capacity reached almost $9 \%$ of OECD electricity capacity in 2011 , up from $5 \%$ in 2007 (IEA, 2012).

Having realised the exceptional potential of this new market, governments offer renewable-energy incentives not only for the mitigation of climate change but also to seek other policy objectives, including increasing access to electricity in rural areas, diversifying energy technologies and resources in order to improve energy security, and fostering economic development through the creation of new jobs. Renewable-energy incentive policies have gained additional momentum in the economic stimulus packages in the aftermath of the financial crisis. According to analysts for the HSBC Bank (Robins et al., 2009), of the nearly USD 2800 billion in tax cuts, tax credits and extra spending announced by the world's economies between October 2008 and the end of January 2009, to be spent from 2009 onwards, almost USD 440 billion was targeted at increasing the supply of low-carbon power, improving energy efficiency, or upgrading water and wastewater infrastructure. Between the autumn of 2008 and the end of 2009, 12 major economies announced research-anddevelopment (R\&D) programmes committing around USD 194 billion to support clean energy, including renewables, energy-smart technologies, carbon capture and storage, and transport (UNEP, 2011).

For many applications, the levelised $\operatorname{cost}^{4}$ of renewable energy is currently higher than for technologies that produce electricity, heat or fuel from fossil fuels. One assumption behind the current incentives is that they will eventually drive down the cost of these technologies, through economies of scale and learning by doing. In that sense, these incentive policies play a critical role in the innovation process of renewable-energy technologies. Some policies focus on creating demand for these technologies in order to pull them into the market place (market-pull policies), while others focus on production of the technology or fuel itself in order to increase supply or foster innovation (technology-push policies). In responding to market-pull policies, entrepreneurs find market opportunities that can be exploited with a new product or existing technology. As the market for a new product develops, competitors appear, and both new and old producers are forced to improve the technology (Bonvillian and

4. The levelised cost of energy is the annualised value, expressed per unit of useful energy (e.g. kilowatt-hour) of the total costs (discounted to the present) of production, including land, labour, capital and operating costs over the lifetime of the relevant production unit. 
Weiss, 2009). Technology-push policies, on the other hand, start with research and development of the technology in its early stages and if successful at each stage, are followed by demonstration, prototyping, and commercialisation. In that sense, technology-push incentive policies, in general, focus mainly on the technology itself, rather than market creation.

Market-pull and technology-push policies make use of a wide range of incentives. For renewable-energy technologies, market-pull incentives can be summarised under four main categories: feed-in tariffs and premiums; quota obligations and tradable renewable certificates; incentives to invest in generating plants; and disincentives to non-renewable energy. Technology-push policies, on the other hand, use financial instruments or equity investments to support technological development and manufacturing. Governments typically implement both market-pull and technology-push policies together, through various combinations of incentive tools.

Climate-change mitigation policies, the incentive-fuelled growth of the renewable-energy industry, and innovations that have lowered the cost of these technologies, have all increased global competition in the industry. Both developed and emerging economies want to be in the forefront of this competition by increasing their capacity to produce goods and services used by the sector, attracting foreign direct investment in manufacturing facilities, and spurring innovation. This situation has led some countries to pursue a pro-active industrial policy focused on renewable-energy technologies. Thus, some of the domestic incentives for renewable energy can also possibly have adverse trade effects.

This paper reviews, through the lenses of market-pull and technology-push policies, the numerous renewable-energy incentives, focussing on those that might have implications for trade - both those that are likely to increase opportunities for trade and those that may be inhibiting imports or promoting exports. The analysis of the links between generic policies and trade is based on generic economic principles, using a simplified stylised representation of the relevant markets.

\section{Organising framework}

\section{The classification of incentives}

There are several ways to examine support measures systematically. Figures 1 and 2 provide a two-dimensional framework similar to the one used by the OECD for organising data on support to agriculture and to fossil fuels. The first dimension highlights the formal incidence of a transfer - i.e. which aspect of production or consumption is targeted. The other dimension, transfer mechanism, relates to how the transfer is created. The framework divides incidence into production (corresponding roughly to technology-push) and consumption (market-pull). Measures supporting production are then further divided into several sub-categories, depending on whether they relate to output returns, enterprise income, the cost of intermediate inputs or value-adding factors - labour, land and natural resources, capital, and knowledge creation. Consumption is divided into direct "green" energy consumption support measures and support measures aiming at financing equipment that delivers cleaner energy or other climate-related services. Consumption can be further divided into "market-based" - i.e. arms-length — incentives, and public procurement. 
Figure 1. Matrix of transfers benefitting consumption and consumer-produced energy, with examples of specific support policies

\begin{tabular}{|c|c|c|c|c|c|}
\hline \multirow{4}{*}{\multicolumn{2}{|c|}{$0^{5}$}} & \multicolumn{4}{|c|}{ Statutory or Formal Incidence } \\
\hline & & \multirow{3}{*}{$\begin{array}{c}\text { Direct } \\
\text { consumption }\end{array}$} & \multicolumn{3}{|c|}{ Equipment } \\
\hline & & & \multirow{2}{*}{$\begin{array}{l}\text { Cost of } \\
\text { intermediate } \\
\text { inputs }\end{array}$} & \multicolumn{2}{|c|}{$\begin{array}{l}\text { Costs of Primary Factors used in } \\
\text { Consumption }\end{array}$} \\
\hline & & & & Land & Capital \\
\hline \multirow{5}{*}{ 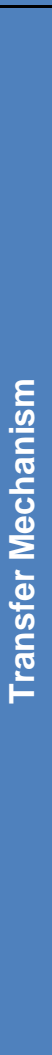 } & $\begin{array}{l}\text { Direct } \\
\text { transfer of } \\
\text { funds }\end{array}$ & Unit subsidy & $\begin{array}{l}\text { Subsidized } \\
\text { installation } \\
\text { service }\end{array}$ & $\begin{array}{c}\text { Capital grant } \\
\text { linked to } \\
\text { acquisition of land } \\
\text { used for } \\
\text { equipment } \\
\end{array}$ & $\begin{array}{l}\text { Capital grant } \\
\text { linked to } \\
\text { acquisition of } \\
\text { equipment }\end{array}$ \\
\hline & $\begin{array}{l}\text { Potential } \\
\text { transfer of } \\
\text { funds or } \\
\text { liabilities }\end{array}$ & $\begin{array}{l}\text { Price-triggered } \\
\text { subsidy }\end{array}$ & & $\begin{array}{l}\text { Credit guarantee } \\
\text { linked to } \\
\text { acquisition of land } \\
\text { required for } \\
\text { equipment }\end{array}$ & $\begin{array}{l}\text { Credit guarantee } \\
\text { linked to } \\
\text { acquisition of } \\
\text { equipment }\end{array}$ \\
\hline & $\begin{array}{l}\text { Tax revenue } \\
\text { foregone }\end{array}$ & $\begin{array}{l}\text { VAT or excise-tax } \\
\text { concession for } \\
\text { good or service }\end{array}$ & $\begin{array}{l}\text { Reduction in VAT } \\
\text { or excise tax for } \\
\text { equipment }\end{array}$ & $\begin{array}{l}\text { Property-tax } \\
\text { reduction related } \\
\text { to land required } \\
\text { for equipment }\end{array}$ & $\begin{array}{l}\text { Tax credit for } \\
\text { acquisition of } \\
\text { consuming } \\
\text { equipment }\end{array}$ \\
\hline & $\begin{array}{l}\text { Other } \\
\text { government } \\
\text { revenue } \\
\text { foregone }\end{array}$ & $\begin{array}{c}\text { Under-pricing of } \\
\text { access to a } \\
\text { natural resource } \\
\text { harvested by final } \\
\text { consumer }\end{array}$ & $\begin{array}{l}\text { Under-pricing of } \\
\text { government } \\
\text { service or use of } \\
\text { infrastructure }\end{array}$ & & \\
\hline & $\begin{array}{l}\text { Induced } \\
\text { transfers }\end{array}$ & $\begin{array}{l}\text { Regulated price; } \\
\text { cross subsidy }\end{array}$ & & & $\begin{array}{c}\text { Credit control } \\
\text { (consumer-class } \\
\text { specific) }\end{array}$ \\
\hline
\end{tabular}

When discussing support policies, it is standard practice to structure the discussion around incidence, in an order reflecting the degree of influence on market outcomes. Generally, policies that directly bear on the level of production or consumption are considered to affect production decisions to a greater extent than subsidies to value-adding factors, like labour. Government support for research and development (R\&D), as long as it is not a form of production support in disguise, is normally considered by economists to be the least distorting. The importance of differentiating among different forms of support according to their incidence is implicitly recognised in the WTO's Agreement on Subsidies and Countervailing Measures (ASCM), where a distinction is made between those subsidies that are prohibited (e.g. subsidies contingent upon export performance or upon the use of domestic over imported goods), and those that are actionable (e.g. subsidies to cover operating losses). 
Figure 2. Matrix of transfers benefitting production, with examples of specific support policies

\begin{tabular}{|c|c|c|c|c|c|c|c|c|}
\hline & & \multicolumn{7}{|c|}{ Statutory or Formal Incidence (to whom and what a transfer is first given) } \\
\hline & & \multirow[t]{2}{*}{ Output returns } & \multirow{2}{*}{$\begin{array}{c}\text { Enterprise } \\
\text { income }\end{array}$} & \multirow{2}{*}{$\begin{array}{l}\text { Cost of } \\
\text { intermediate } \\
\text { inputs }\end{array}$} & \multicolumn{4}{|c|}{ Costs of Production Factors } \\
\hline \multicolumn{2}{|c|}{$p^{*}$} & & & & Labour & Land & Capital & Knowledge \\
\hline ষ্ণ & $\begin{array}{l}\text { Direct } \\
\text { transfer of } \\
\text { funds }\end{array}$ & $\begin{array}{c}\text { Output bounty or } \\
\text { defficiency } \\
\text { payment }\end{array}$ & Operating grant & $\begin{array}{l}\text { Input-price } \\
\text { subsidy }\end{array}$ & Wage subsidy & $\begin{array}{c}\text { Capital grant } \\
\text { linked to } \\
\text { acquisition of land }\end{array}$ & $\begin{array}{l}\text { Capital grant } \\
\text { linked to capital }\end{array}$ & Government R\&D \\
\hline 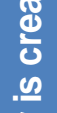 & $\begin{array}{l}\text { Tax revenue } \\
\text { foregone }\end{array}$ & $\begin{array}{r}\text { Production tax } \\
\text { credit }\end{array}$ & $\begin{array}{l}\text { Reduced rate of } \\
\text { income tax }\end{array}$ & $\begin{array}{l}\text { Reduction in } \\
\text { excise tax on } \\
\text { input }\end{array}$ & $\begin{array}{l}\text { Reduction in } \\
\text { social charges } \\
\text { (payroll taxes) }\end{array}$ & $\begin{array}{l}\text { Property-tax } \\
\text { reduction or } \\
\text { exemption }\end{array}$ & $\begin{array}{l}\text { Investment tax } \\
\text { credit }\end{array}$ & $\begin{array}{l}\text { Tax credit for } \\
\text { private } R \& D\end{array}$ \\
\hline 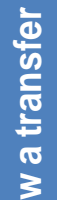 & $\begin{array}{l}\text { Other } \\
\text { government } \\
\text { revenue } \\
\text { foregone }\end{array}$ & $\begin{array}{l}\text { Reduced royalty } \\
\text { payments }\end{array}$ & & $\begin{array}{c}\text { Under-pricing of a } \\
\text { good, government } \\
\text { service or access } \\
\text { to a natural } \\
\text { resource }\end{array}$ & & $\begin{array}{l}\text { Under-pricing of } \\
\text { access to } \\
\text { government land }\end{array}$ & & $\begin{array}{l}\text { Government } \\
\text { transfer of } \\
\text { intellectual } \\
\text { property right }\end{array}$ \\
\hline$\frac{E}{\frac{D}{2}}$ & $\begin{array}{l}\text { Transfer of } \\
\text { risk to } \\
\text { government }\end{array}$ & $\begin{array}{l}\text { Government buffer } \\
\text { stock }\end{array}$ & $\begin{array}{l}\text { Third-party liability } \\
\text { limit for producers }\end{array}$ & $\begin{array}{c}\text { Provision of } \\
\text { security (e.g., } \\
\text { military protection } \\
\text { of installations) }\end{array}$ & $\begin{array}{c}\text { Assumption of } \\
\text { occupational } \\
\text { health and } \\
\text { accident liabilities }\end{array}$ & $\begin{array}{c}\text { Credit guarantee } \\
\text { linked to } \\
\text { acquisition of land }\end{array}$ & $\begin{array}{l}\text { Credit guarantee } \\
\text { linked to capital }\end{array}$ & \\
\hline 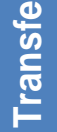 & $\begin{array}{l}\text { Induced } \\
\text { transfers }\end{array}$ & $\begin{array}{l}\text { Import tariff or } \\
\text { export subsidy }\end{array}$ & $\begin{array}{l}\text { Monopoly } \\
\text { concession }\end{array}$ & $\begin{array}{c}\text { Monopsony } \\
\text { concession; } \\
\text { export restriction }\end{array}$ & Wage control & Land-use control & $\begin{array}{l}\text { Credit control } \\
\text { (sector-specific) }\end{array}$ & $\begin{array}{c}\text { Deviations from } \\
\text { standard IPR rules }\end{array}$ \\
\hline
\end{tabular}

Source: OECD. 
Turning to trade, measures aimed at increasing the domestic supply of technologies or services are more likely to affect trade flows in an adverse way than pure demand-side measures, which can actually stimulate them. The trade-distorting impact of supply-side policies should be stronger the greater they favour local suppliers over foreign competitors. Market-pull measures, however, can also be trade-distorting, depending on what other measures are in place - e.g. whether they are accompanied by regulations based on national standards that diverge from international norms (where applicable); domestic-content requirements or "Buy Local" preferences in government procurement; and the existence of trade barriers, particularly to key goods and services.

The trade-distorting impact of various support measures also has an important bearing on these measures' likely environmental impacts. While domestic incentive measures for renewable energy are typically introduced with a view to reducing a country's reliance on carbon-intensive energy sources, this reduction is clearly contingent upon the pace at which renewable-energy equipment is made available throughout the economy. International trade can accelerate this process by providing access to cheaper renewableenergy equipment or inputs and by facilitating the diffusion of new technologies embodied in imported goods. Also potentially relevant from an environmental standpoint are the conditions under which renewable energy is produced on a lifecycle basis. Support measures encouraging the use of particular intermediate inputs - like fertilizers in the case of biofuels or certain specific mined commodities in the case of renewableenergy equipment - can eventually have adverse environmental impacts that run counter to the initial goal of reducing atmospheric pollution and carbon emissions. Any assessment of those impacts would, however, require large amounts of detailed information and is beyond the scope of this report.

\section{Government incentives from a dynamic perspective: The innovation imperative}

Although at any one moment governments may be supporting multiple stages in the value chain of a particular fuel or technology, there is generally a logic behind the sequencing of support policies. One of the principle goals of most governments that support renewable energy is to encourage innovation in a way that yields constant improvement in price and performance (Tawney etal., 2011). Government involvement in pushing technological innovation has been inspired by the work of the economist Joseph Schumpeter (1934), who regarded innovative technologies as the essential forces behind social and economical changes. In Schumpeter's view, though process innovations are vital, only product innovations can give rise to new industries. Policies that support new invention and innovation, through $\mathrm{R} \& \mathrm{D}$, production and sales, are nowadays referred to as "technology push" (Figure 3).

But technology-push policies are, to the economist Jacob Schmookler (1966), like one blade in a pair of scissors. As he and others since have shown, the pull of market demand is also important: the more intense the demand, the more creative groups and individuals are drawn to work on an unsolved problem and the more inventions they generate. ${ }^{5}$ Nowadays, therefore, experts recognise the innovation process as being dynamic and complex, acknowledging that it can take place anywhere in the lifecycle of a product, and not necessarily in a predetermined or predictable sequence. There are many feedback loops, with innovators constantly moving "back and forth between stages while trying to meet all the

5. See, for example, Henry W. de Jong and William G. Shepherd, eds. (2007), Pioneers of Industrial Organization: How the Economics of Competition and Monopoly Took Shape, Edward Elgar, Cheltenham. 
market criteria for a solution" (Tawney et al., 2011). Policies that count on this feedback also acting as a spur to innovation are usually referred to as "market pull" policies.

Figure 3. Stylized stages of government intervention to support new technologies

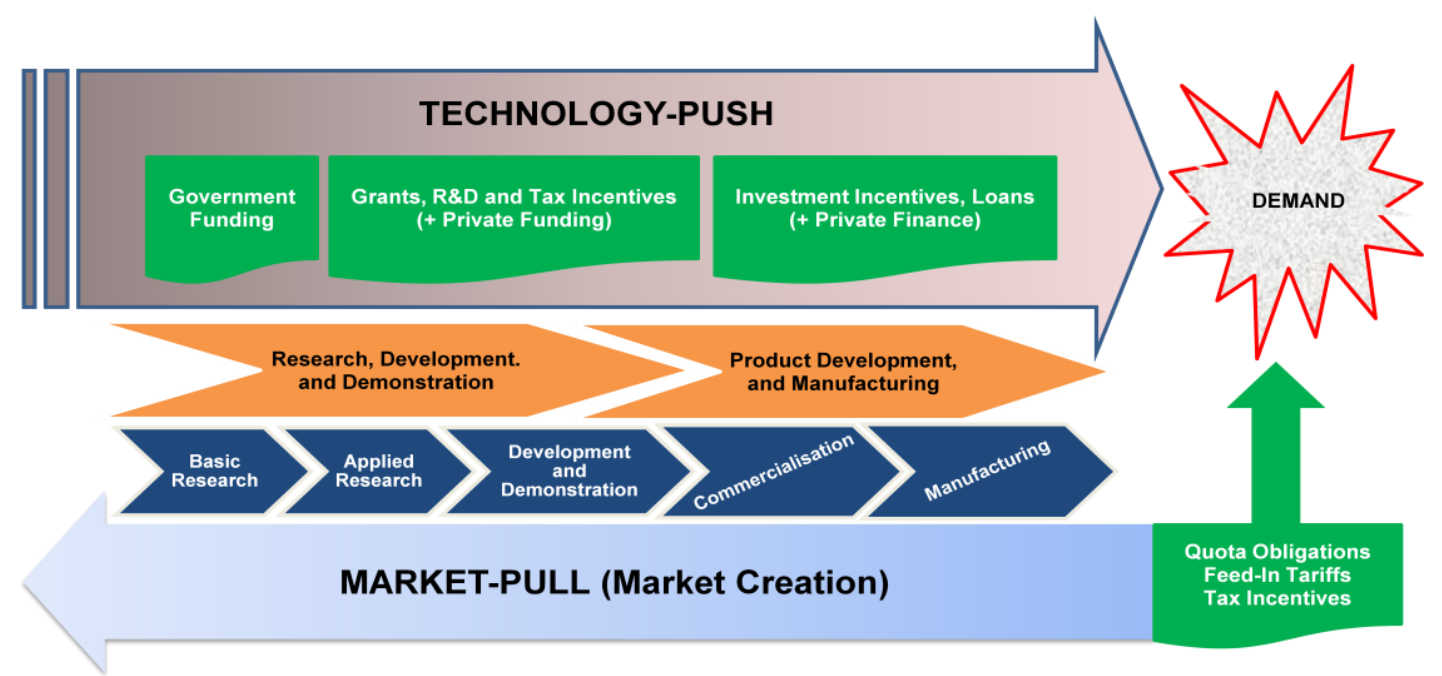

Source: OECD.

Dynamism and complexity are apt descriptors of innovation in the low-carbon electric power sector. As observed by Tawney et al. (2011), this market has a set of characteristics that strongly shape the innovation process (emphasis in the original):

- "Because low-carbon technologies integrate with a very mature power sector, they are simply providing a commodity and as a result are price takers. They cannot charge a premium for the innovations they offer.

- Very large investments are needed for many innovations and it can take a long time to reap the benefits of those investments. This also makes updating designs and experimenting very slow.

- There are diverse sources of new knowledge in the sector: science, suppliers, customers, and others. Effectively accessing them is critical.

- Knowledge is often tacit (learned through experience rather than through blueprints or scientific articles). Even when it is not tacit, it is often not effectively controlled.

- There are many opportunities to innovate, as the technologies are not yet mature.

- There are few new entrants and a relatively important role for large, global players. New entrants can rapidly move into the top tier with good strategies.

- There is a strong geographic clustering of innovators, often near customers."

The "technology push" strategy that any particular country follows depends in part on its technological capacity. This capacity depends not only on financial resources, but also on the knowledge and skills of its labour force and of its universities and research centres. Countries endowed with such resources will typically invest in all stages of technology and product development - from the financial and tax incentives for R\&D to export credits in order to encourage foreign sales. Basic research is heavily funded by many governments, either in government laboratories or through (almost always) domestic universities. As research and development gets closer to commercial relevance, it often involves public-private partnerships, and generally an increasing share of the cost is shouldered by the private firms that stand to benefit from the knowledge thus created. In some countries and for some 
products only domestic domiciled firms participate in these partnerships; in others, foreign firms are invited in.

Countries that are unable to invest in $R \& D$ at the early stages of a technological development (before their potential competitors) typically provide incentives for foreign companies to set up production within their borders - e.g. by providing tax incentives (for example, in the form of tax holidays) or joint ventures - in order to encourage the transfer of technological know-how.

Whether competitive advantage is created for domestic companies through such policies, and how long the advantage lasts, is disputed. Some research has shown that a first-mover advantage in the market for renewable-energy products, among others, can be a very important determinant of success (Connor, 2004; Kamp et al., 2004). For example, the dominance of German and Japanese firms in the supply of solar PVs, before competitors especially from China - had caught up, is said to have benefitted from a first-mover advantage. ${ }^{6}$ However, because the degree to which the knowledge from R\&D spills out and benefits foreign as well as domestic firms varies, it is difficult to generalise about the effects of government support for R\&D on trade (see Voituriez and Balmer, 2012).

At the next stages of pushing the technology into the market, governments incentivise product development, manufacturing and its market penetration, especially abroad. Many governments still support companies at these stages - mainly by promoting their domestically developed products and technologies in markets overseas - though private investment usually plays a bigger role. Governments in the countries with low technological capacity may at this stage create incentives for foreign companies to exchange their technological know-how for an access to their domestic markets, usually in the forms of joint ventures. Government incentives at these stages of technology development are potentially distorting to the extent to which they favour domestic or local producers over the others, or if they provide incentives to both international and domestic companies to produce locally.

Market-pull policies work in the reverse direction from technology-push policies. The theory is that "[n]ew market opportunities give rise to an invention, which will eventually create requirements for development and lastly for new research" (Bonvillian and Weiss, 2009). A change in market conditions gives the industry an incentive to innovate in order to meet the changed patterns of demand. This change may be a major increase or decrease in input prices or a strict code or regulation by governments. Market-pull policies mainly consist of regulations and incentives aimed at expanding the share of renewable-energy technologies and fuels in the broader market for electricity and transport fuels. However, the size of this new global market has prompted some governments to assist in the development of their national manufacturing capacity, in some cases by adopting policies that ensure that a significant portion of the equipment used is locally manufactured.

Governments are also indirectly influencing investment in renewable energy by incentivising state-owned pension funds and private funds to make such investments (Box 1). The probability of governments incentivising such funds to invest in particular industries, including renewable energy, is likely to increase in the future, given both the large capital requirements of renewable energy and associated infrastructure and the poor state of many governments' finances. ${ }^{7}$ In light of limited public resources, governments realise that effective

6. The crucial test of whether there really is a first-mover advantage is whether or not a higherthan-normal profit is been made by the benefitting firms.

7. The IEA (2010) has estimated that USD 46 trillion must be spent between 2010 and 2050 in order to meet 2050 targets on climate change, with half of this sum being expenditure on clean infrastructure. 
and efficient leveraging of alternative funding will be critical to enabling large-scale financing to transform the energy and transportation sectors in a given country. One idea that has been proposed (see Della Croce et al., 2011) is "green bonds" - i.e. bonds supported by government guarantees. In countries with high-interest rates, green bonds have the potential to attract support from investors from richer nations.

\section{Government incentives from a static perspective}

For a given technology there is often a life cycle of different incentives, with certain types used more intensely in the early stages of the technology and others once it becomes more mature. Accordingly, because the market for any given class of electricity-generating sets (e.g. wind turbines) or fuels (e.g. renewable gasoline substitutes) are usually supplied by products that have involved different manufacturing techniques, at any one moment multiple incentives are likely being provided to broad categories of renewable energy (solar power, wind power, biofuels, etc.). Moreover, many incentives are in theory supposed to expire after an industry or technology reaches a certain stage of development, but often they do not. Since trade is affected in real time by actual market forces and the totality of incentives influencing market outcomes, it is also important to understand those incentives from a static perspective.

\section{Box 1. Pension-fund investment in green technologies}

Several OECD member states - e.g. Austria Germany, Italy and the United Kingdom - require pension funds to submit reports on their SRI (socially responsible investing) policies. Although this requirement imposes no sanctions for not reporting, it may indirectly encourage investment in green technologies. In addition, some OECD countries, such as Belgium and the Netherlands - provide tax breaks for SRI.

A few governments are contemplating forcing pension funds to invest in sectors that they deem economically strategic, particularly infrastructure. This proposal has gained many supporters as fiscal austerity pushes both governments and the industry to reach out to new sources of project financing. During the recent Global Green Growth Forum (Copenhagen, 11-12 October 2011), for example, representatives of the biofuels industry proposed earmarking finance for innovation in biofuels directly from pension funds. Another example can be found in Australia's 2011-12 Commonwealth Budget. The government, seeking new sources of funding for infrastructure projects, is contemplating earmarking for investment in infrastructure a part of the AUD 1.4 trillion in assets currently held by pension funds in Australia. An expert group tackling this issue has also suggested that pension funds should be incentivised to hold more "greenfield assets" (i.e. assets of those companies that operate in newly established sectors of the economy or on a territory where there was no previous economic activity), as opposed to "brownfield" projects (Della Croce et al., 2011).

Norway's state pension fund, which only makes investments abroad, encourages investment in renewable-energy technologies more explicitly. Norway is the only state in the world to have formulated "ethical regulations" for its pension fund, the central feature of which is "active ownership". Under this regulation, the pension fund informs companies of the general ethical standards they must meet if they wish to be considered as potential investees. One of the ethical regulations stipulates that a business should be excluded if it significantly contributes to environmental damage. During the time since the ethical regulations have been in place, the Norwegian pension fund has banned 28 companies from its portfolio, six of which for committing serious environmental violations. Also, since the Norwegian pension fund has to deal with an asset selection pool of about 8000 businesses, it sets internal preferences for "active membership" though focusing on particular regions and sectors in which it should invest. As for environmental protection, the fund decided to invest in climate protection in the United States and earmarked investment for major US enterprises in the fields of energy and transport whose policies have significant impact on climate change. Moreover, the Norwegian pension fund is planning to extend its "ethical regulations" by making "positive selection" a future investment strategy. One of the measures proposed under the positive selection is that fund assets will focus on particular areas for investment. The closest candidate for becoming such an area of focus is said to be the renewable-energy sector (Reiche, 2010).

continued 
A Danish Pension Fund (Pension Danmark) is currently planning to invest about $10 \%$ of its total EUR 18.5 billion in assets into the renewable-energy power generation sector, focusing on wind parks and solar PV power in Denmark, the Netherlands, Sweden and the United Sates. Also for this purpose, the fund has formed a joint venture with the Danish Oil and Natural Gas Group, a semi state-owned utility. The pension fund expects a return on investment above the yield on government bonds and considers this business opportunity to be less risky than investment in other sectors, mainly owing to the implementation of FITs for renewable-energy sources. Also, the investment in this type of economic activity is very attractive to the pension fund, as the economic performance of the renewable-energy power generation in the countries it targets is almost totally divorced from the general economic business cycle. The fund plans to invest an additional USD 2.2 billion in wind energy and other infrastructure assets over the next five years after investing USD 1.1 billion into investments such as three US offshore wind parks and two Danish offshore parks (Kaminker et al., 2013).

Figures 4 and 5 provide schematic illustrations of how government interventions support different stages of production and consumption of renewable energy, and also storage and transport (where applicable). For the purpose of this report, the "supply" of equipment for generating electricity or heat from renewable-energy-based electricity-generating plant pertains only to those activities preceding and including the manufacture of the equipment and related components, whereas the "supply" of biofuels includes storage and transport and all upstream activities. From a trade perspective, it is the biofuels and the renewable-energy equipment (whole generating sets or their components and spare parts) that enter international commerce and therefore are of greatest interest. ${ }^{8}$

In the case of both value chains, subsidies may exist to what economists call "intermediate inputs" - goods and services that are consumed in the production process. In the case of biofuels, these can include subsidies to producers of feedstock crops used to make the biofuels, and perhaps cheap energy for processing. Subsidies to intermediate inputs in the manufacture of electricity-generating sets are not commonplace, but could include subsidised materials or electricity. Subsidies to intermediate inputs are often complemented by support to value-adding factors: capital goods; land; and occasionally labour employed directly in the production process. These may take the form of grants, or reduced-cost credit, for the building of manufacturing plants. Some localities are providing land for manufacturing plants for free or at below market prices as well. These forms of support lower both the costs and the investor risks of new manufacturing plants, improving the return on investment.

Some manufacturing facilities receive government support directly linked to outputs. Output-linked support includes protection from foreign competition through import tariffs ("border protection"), and grants or tax credits related to the quantity of units produced or sold ("bounties"). Bounties for biofuels have occasionally had the effect of actually depressing the prices of the biofuel below the energy-equivalent cost of a competing petroleum fuel, but mainly they have enabled biofuels to be sold at retail prices that are roughly at parity with their (taxed) fossil-fuel counterparts. In some cases, tax credits given when the fuel has been blended have also benefitted export shipments of the fuels. Bounties for the manufacturing of renewable-energy generating plants are rare (this study has found only one'), but domestic-content requirements attached to measures can have similar production-stimulating effects as bounties.

8. Electricity generated by renewable-energy plants is also traded internationally, but the implications of support measures for this trade are not considered in this paper. Another JWPTE paper, "Cross-border trade in electricity and the development of renewables-based electric power" [COM/TAD/ENV/JWPTE(2012)20/REV1] sheds more light on this issue.

9. This pertains to a tax credit provided by the US State of Oklahoma to manufacturers of wind turbines; see Appendix 2. 
Figure 4. Static view of points of government support in the electricity generation value chain

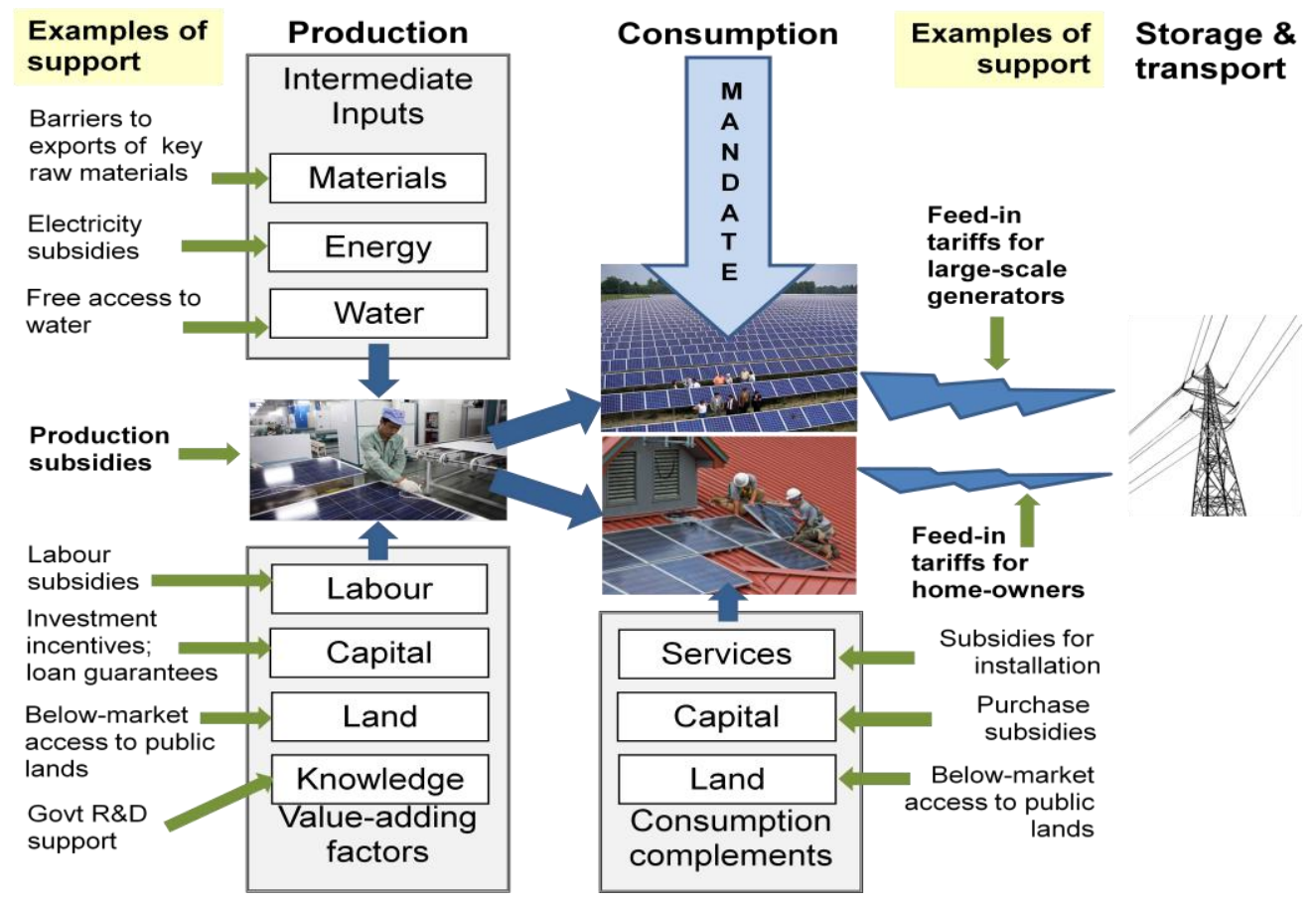

Figure 5. Static view of points of government support in the biofuels value chain
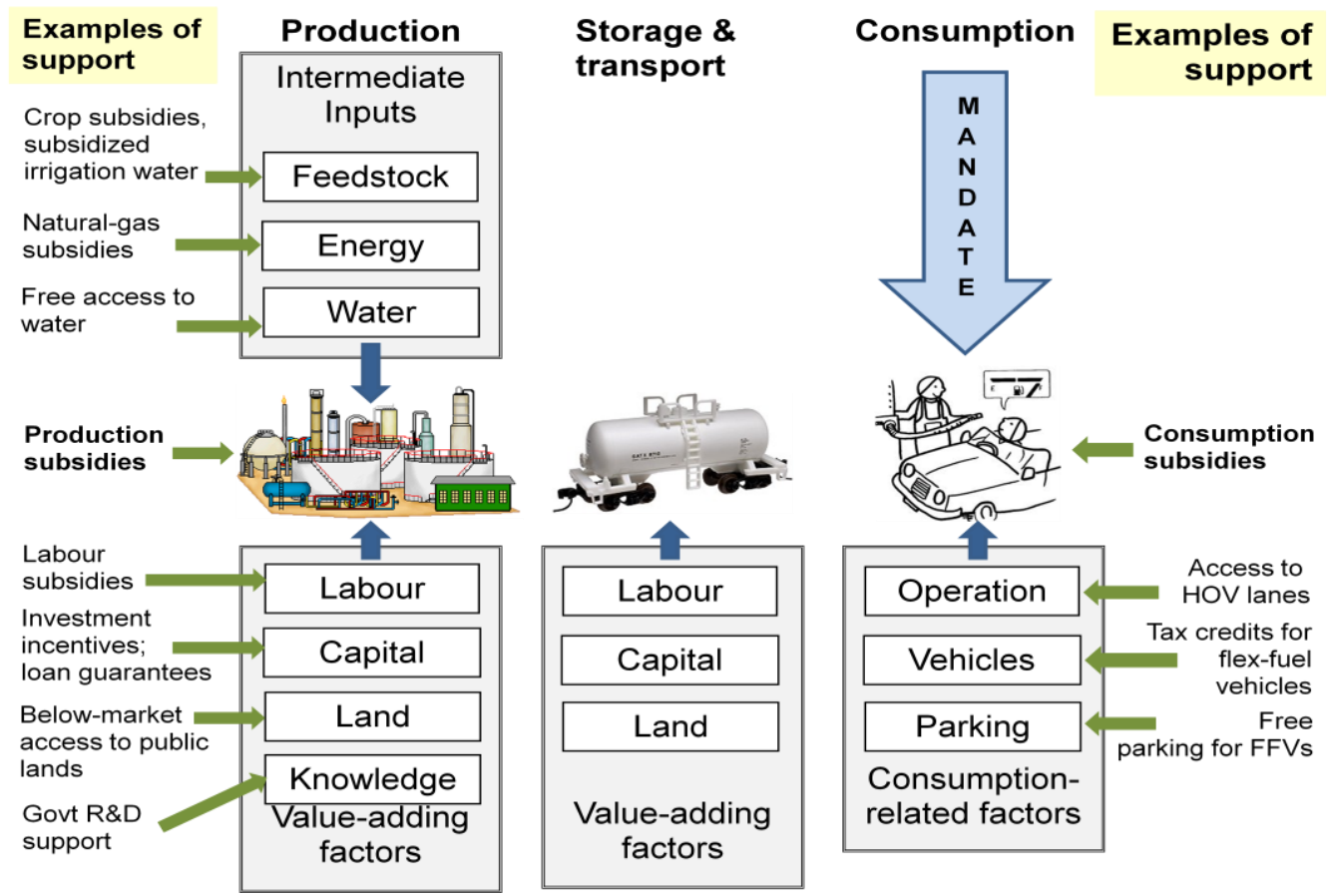

Source: Adapted from Steenblik (2007). 
Support to the downstream side of the biofuels market is generally being provided in one of five ways: credit to help reduce the cost of storing biofuels, which often have to be segregated from fossil fuels until just before blending; grants, tax credits and loans to build dedicated infrastructure for the wholesale distribution and retailing of biofuels; grants to demonstrate the feasibility of using biofuels in particular vehicle fleets (e.g. biodiesel in municipal buses); measures to reduce the cost of purchasing biofuel-capable fleets; and government procurement programmes that give preference to the purchase of biofuels.

Regarding policies bearing on consumption, both the markets for biofuels and the markets for other forms of renewable-energy have benefitted from government intervention intended to pull these goods into their markets: liquid fuels and electricity (or heat). In the case of liquid fuels, the market comprises a large number of private consumers of fuels for their own vehicles, and a smaller but significant market of buyers for fleets of vehicles or aircraft. In the case of electricity-generating units based on renewable-energy, the "market" is also segmented, generally between public utilities, which are typically the buyers of the large-scale plants (i.e. plants producing several to hundreds of megawatts of electricity or heat), and households, which are typically the buyers of small-scale plants (i.e. those producing hundreds of watts or a few kilowatts of electricity or heat). Governments support such consumption through a myriad of incentives, including both financial incentives for the purchase and installation of electricity-generating equipment or fuels, and bounties for the electricity or heat produced from the equipment.

Undergirding the market for both biofuels and renewable-energy plant in many countries are government-imposed regulations requiring that certain shares (or amounts) of liquid fuels or electricity used within a jurisdiction are sourced from renewable energy. As such, consumption mandates increase the domestic demand for the goods (and services) required to meet the mandate, and in the absence of other policies, can be expected to draw in imports. However, if barriers to imports exist, they can turn a consumption stimulus into a stimulus for local supply as well.

\section{Main findings}

In surveying the policies currently in use (see Annex 1 for more detail), the paper finds that many OECD countries, and an increasing number of non-OECD countries, have established national targets for renewable energy, typically to be achieved by 2020 , but in some cases earlier. Many of these targets are only aspirational, but some - like those established by the European Union's Renewable Energy Directive (RED) - are legally binding. Some of them cover all forms of renewable energy, while others are specific to electricity or transport fuels, or both. Of the targets specific to electricity, some can be met by hydro-electric plants, while others are specific to so-called non-conventional renewable energy. Where the targets are binding, systems for crediting renewable-energy production or sales ("green" certificates) are usually created.

To help boost the rate of penetration of renewable energy in their economies, many countries also use market-based instruments that favour electricity generated from renewable energy or renewable fuels. With respect to electricity, the most common policies are special "feed-in" tariffs (FITs) that either guarantee a fixed price for electricity sold to the electricity grid, usually for at least a decade, or a fixed premium per kilowatt-hour sold. The extra costs of these FITs and premiums are usually passed on to electricity consumers, but in a few countries they are paid out of government funds. While a few governments set uniform FITs or premiums, most differentiate among renewable-energy sources, guaranteeing higher prices for electricity generated by more-expensive and less mature technologies. Also, many national and sub-national governments support the installation of renewable-energy-based electricitygenerating facilities, typically with grants, subsidised loans, loan guarantees, or a combination 
of instruments. Finally, many countries indirectly support renewable energy by disincentivising the production and consumption of fossil-fuel energy, through measures such as taxing fossil fuels, regulating emissions from power plants, and instituting emissions trading schemes.

The main market-based instruments used to favour the consumption of renewable fuels for transport are exemptions from, or reductions in, fuel-excise taxes, and tax credits for companies that blend these fuels with petroleum fuels. The practice of fully or partially exempting renewable fuels from excise taxes seems to be waning, especially in countries that have established mandatory blending quotas. These tax preferences have, in any case, only applied to renewable fuels used for surface transport, as bunker fuels used for international aviation are generally not taxed. In addition to the measures directly targeted at fuels, many governments also try to encourage the use of renewable fuels through offering incentives for the purchase and operation of vehicles that are capable of running on high-percentage blends of these fuels, and for the construction of fuel-distribution facilities, and by helping to fund experiments to test the performance of renewable fuels in particular engines. A few, mainly sub-national, jurisdictions have linked implementation of their biofuel-content mandates with the development of in-state or in-province manufacturing capacity for the mandated fuel, and a few have tied eligibility for subsidies or tax preferences to the use of locally produced biomass feedstock.

The technology-push policies that countries have adopted appear to be related in part to their technological capacities. Most OECD countries have extensive research, development and demonstration (RD\&D) programmes relating to renewable energy that they carry out either on their own or in co-operation with other countries. In 2011, they spent at least USD 4.1 billion on RD\&D related to renewable energy, according to data from the IEA (www.iea.org/stats/rd.asp). Developing and emerging countries that are unable to invest in RD\&D at the early stages of technological development (before their potential competitors) typically provide incentives for foreign companies to set up production within their borders in order to encourage the transfer of technological know-how. In addition, many governments, both in the OECD and among the larger emerging economies, provide assistance to companies that set up facilities to manufacture renewable-energy technologies or renewable fuels. The forms of assistance involve all manner of instruments, ranging from grants to government loan guarantees. Some of this assistance is provided through special programmes that have been established to stimulate investment by manufacturers that are pioneers in the commercial-scale use of new technologies. An additional large infusion of assistance was channelled to manufacturers through various economic stimulus packages created in the wake of the 2008-09 economic crisis. Other assistance packages, especially those provided by subnational governments, are funded through general economic-development policies.

Although the focus of this study is on domestic incentive measures, these cannot be looked at in isolation. Often, incentives interact with trade barriers in ways that substantially alter the effects that the incentives would have in the absence of such barriers - for example, turning a policy that might otherwise increase imports of the affected goods into one that favours domestic suppliers. In this regard, the paper shows that applied import tariffs on renewable-energy-based electricity-generating equipment are generally zero to $10 \%$ in most OECD and major non-OECD economies. (These are the highest tariffs applied to other WTO member economies, as trade among partners in bilateral and regional free-trade agreements is usually duty free.) Brazil and the Russian Federation are important exceptions, with applied tariffs of $14 \%$ and $15 \%$, respectively, on hydraulic turbines. Generally, across the economies examined, import tariffs are slightly higher for hydraulic turbines than for wind-powered generating sets and are on average higher among non-OECD than OECD countries. In addition, some countries impose import tariffs on raw materials that are used to produce some renewable energy technologies. Moreover, whereas the tariffs applied by OECD countries on 
these goods are close to their corresponding bound tariffs, tariffs applied by many non-OECD countries are a fraction of their bound tariffs. This large gap creates long-run uncertainty for suppliers selling into these markets (Tables A6 and A10).

The tariff situation for renewable fuels is vastly different from that of power-generating equipment. Import duties on fuel ethanol (ethyl alcohol) are often expressed as specific-rate tariffs, and on an ad valorem-equivalent basis in many countries - including some OECD countries - exceed 20\%. On imports of undenatured ethanol, the Russian Federation charges a $100 \%$ tariff, and India a 150\% tariff. By contrast, import duties on biodiesel are generally less than 10\%, except in Argentina and Brazil, which charge 14\%. As with power-generating equipment, the gap between bound and applied tariffs is wide.

The rapid growth in demand for renewable-energy technologies has raised a two-pronged concern: whether the various incentives being provided are effective in reducing $\mathrm{CO}_{2}$ emissions, and what the trade implications of these policies are. The conceptual analysis of the possible trade impacts of policies supporting the renewable-energy sectors (see Annex 2 for detail) sheds more light on the latter question. It investigates, in purely conceptual terms, the potential trade effects of several generic types of policies, as well as combinations of these policies. ${ }^{10}$ The analysis is based on general economic principles, using a simplified stylised representation of the relevant markets. Following are the main insights from the analysis:

- While all forms of government support for the purchase of renewable-energy equipment indirectly affect trade to the extent that they affect the relative market prices at home and abroad, they are not protectionist per se. Demand-pull policies in isolation increase the domestic supply of renewable energy and facilitate trade in associated technologies and renewable fuels. Their main possible impacts on other countries are pecuniary: the extra demand stimulated by domestic incentives may cause international prices for the technologies or fuels to increase, at least in the short run. This may also bring forth extra global capacity over the longer term. Combinations of such support measures with more or less explicit trade barriers can, however, yield protectionist outcomes. This occurs when the link between changes in the domestic market for renewable energy (both on the demand and supply sides) and the desired level of imports is severed: when trade barriers are in place, the stimulating effect on demand or supply on the domestic market resulting from government support policies can no longer be met through an increase or decrease in imports from the ROW. Instead, increased demand or supply tend to benefit only or mostly domestic producers. For example, demand-pull policies such as FITs may become protectionist when implemented along with an import tariff or domestic-content requirement on the essential inputs, namely renewable-energy equipment. Such import tariffs and domestic-content requirements can raise the domestic prices of renewableenergy equipment and related services as well as shield domestic industries from foreign competition. When demand-pull policies are combined with border protection or domestic-content requirements, however, trade is distorted, reducing export opportunities for foreign suppliers.

- Market-push policies, such as government support for research and development, can provide a benefit for domestically established firms, but the spill-over knowledge it generates can also benefit suppliers elsewhere, depending on the stage of technological development. Support provided to domestic manufacturing may promote learning by doing, but can also distort trade by reducing the manufacturers' costs and improving their competitive position vis-à-vis foreign manufacturers. If substantial, and the country is a major producer, such support can also end up depressing world prices. In the short run, 
this benefits consumers of the technologies or fuels, but it can also precipitate the closure of non-subsidised manufacturers.

- Policies that support renewable energy can alter the equilibrium price in these markets, affecting investment, production and consumption decisions. While market-pull policies exert an upward pressure on the domestic prices of renewable-energy equipment, support for investment in manufacturing is likely to drive the market prices down. In both cases, the financial burden of support is carried by electricity ratepayers or taxpayers (depending on the financing of policies in question), while existing domestic producers are likely to capture super-normal profits.

- Not only do market-pull and technology-push incentives affect the market price level of renewable-energy equipment, they can also produce various knock-on effects in other markets. This is particularly relevant for measures that support the production or use of biofuels, which may have strong effects on the price level in the market for fuel and feedstock crops, and - by extension - on prices of food and land.

- Renewable-energy support policies also aim at correcting market failures. These market failures may take the form of knowledge spillovers from learning-by-doing, or R\&D spillovers. Since the value of these positive externalities is not fully captured by the firms that generate them, they may undertake less of the activities that generate them than would be socially optimal. If different renewable-energy technologies suffer from different market failures, then implementing technology-neutral policies to address these market failures may not be optimal. On the other hand, government support for specific technologies usually involves "picking winners" and, as a consequence, may drive investment away from the most economically efficient technologies to those that enjoy government support.

- Given that "getting the prices right" on emissions raises electricity prices and improves the competitiveness of renewable energy, large additional subsidies for renewable energy may not be necessary. However, technologies at an early stage of development may require additional, targeted measures in order to achieve deployment.

In short, it is clear that governments need to carefully design support policies for renewable energy to avoid, in particular, adverse effects on international trade.

Ensuring that domestic-incentive policies are compatible with WTO subsidy rules is just as important for renewable-energy technologies and fuels as it is for other goods. It suggests also that full transparency on domestic incentives, including through the WTO subsidynotification process, would be helpful both in keeping trading partners informed and in promoting best practice in the use of domestic incentive measures. 


\section{Annex 1.}

\section{A survey of policies supporting renewable energy and biofuels}

\section{Electricity-generating technologies}

\section{Market-pull policies}

The levelised cost of electricity generated from renewable energy sources, other than hydro-electricity, continues to be higher than that from coal and natural gas in most circumstances. Considering that electrons produced by generators are the same, no matter what the energy source, it is difficult to expect - as long as renewable energy is more expensive than fossil energy - that market forces alone will drive investment in expensive renewable-energy technologies. Market-pull policies for the deployment of renewable energy aim at creating market opportunities for these technologies. These market-pull policies mainly include quota systems, usually administrated through "green" certificates, feed-in tariffs and premiums, and incentives for deployment. Governments also use different combinations of these policies. However, the creation of a new "artificial" market, which otherwise would not have existed due to competition with conventional technologies, through market-pull policies can have trade implications depending on their design and administration.

\section{Quota systems and tradable renewable certificates}

Quota systems are generation-based, quantity-driven instruments. They are also known as Renewable Portfolio Standards (RPSs) in the United States, Renewable Electricity Standards in India, Renewables Obligation (RO) in the UK, and Renewable Energy Targets (RET) in Australia. Under quota systems, governments typically place an obligation on a utility company, group of companies or consumers to provide (or consume) a pre-determined minimum share of renewable energy of either installed capacity or electricity generated (or consumed). Usually, utilities must pay a penalty for non-compliance. In 2008, the European Commission published its 20-20-20 policy, which calls for reducing the European Union's greenhouse gas emissions by $20 \%$, and to increase the proportion of final energy consumption from renewable resources to $20 \%$, both by 2020. The EU's Directive on renewable energy has set different targets for all member states based on their existing renewable electricity (Table A.1). In the United States, a federal RPS has been discussed but not yet implemented. Nevertheless, 31 states have established RPSs with different targets, ${ }^{11}$ and six states ${ }^{12}$ have set voluntary goals for adopting renewable energy instead of portfolio standards with binding targets (DOE, 2013a). Several countries in Latin America have also established targets for renewable

11. Arizona, California, Colorado, Connecticut, District of Columbia, Delaware, Hawaii, Illinois, Iowa, Kansas, Maine, Maryland, Massachusetts, Michigan, Minnesota, Missouri, Montana, Nevada, New Hampshire, New Jersey, New Mexico, New York, North Carolina, Ohio, Oregon, Pennsylvania, Rhode Island, Texas, Washington, West Virginia, and Wisconsin. 
energy from electricity (Table A.2). Many other developing countries have introduced non-technology-specific, non-binding targets for renewable energy. ${ }^{13}$

Table A.1. EU-27 National Renewable Energy Targets for 2020 as stipulated by the Directive 2009/28/EC

\begin{tabular}{|c|c|c|c|}
\hline \multicolumn{4}{|c|}{ Renewable energy $\%$ as a share of gross final energy consumption } \\
\hline & 2005 (share) & 2009 (share) & 2020 (target) \\
\hline Austria & 23.3 & 29.2 & 34 \\
\hline Belgium & 2.2 & 3.8 & 13 \\
\hline Bulgaria & 9.4 & 11.5 & 16 \\
\hline Cyprus (See notes 1 \& 2) & 2.9 & 3.8 & 13 \\
\hline Czech Republic & 6.1 & 8.5 & 13 \\
\hline Denmark & 17 & 19.7 & 30 \\
\hline Estonia & 18 & 22.7 & 25 \\
\hline Finland & 28.5 & 29.8 & 38 \\
\hline France & 10.3 & 12.4 & 23 \\
\hline Germany & 5.8 & 9.7 & 18 \\
\hline Greece & 6.9 & 7.9 & 18 \\
\hline Hungary & 4.3 & 9.5 & 13 \\
\hline Ireland & 3.1 & 5.1 & 16 \\
\hline Italy & 5.2 & 7.8 & 17 \\
\hline Latvia & 32.6 & 36.8 & 40 \\
\hline Lithuania & 15 & 16.9 & 23 \\
\hline Luxembourg & 0.9 & 2.8 & 11 \\
\hline Malta & 0 & 0.7 & 10 \\
\hline Netherlands & 2.4 & 4.2 & 14 \\
\hline Poland & 7.2 & 9.4 & 15 \\
\hline Portugal & 20.5 & 25.7 & 31 \\
\hline Romania & 17.8 & 21.6 & 24 \\
\hline Slovak Republic & 6.7 & 10 & 14 \\
\hline Slovenia & 16 & 17.5 & 25 \\
\hline Spain & 8.7 & 13 & 20 \\
\hline Sweden & 39.8 & 50.2 & 49 \\
\hline United Kingdom & 1.3 & 2.9 & 15 \\
\hline EU27 & 8.5 & 11.6 & 20 \\
\hline
\end{tabular}

1. Note by Turkey: The information in this document with reference to "Cyprus" relates to the southern part of the Island. There is no single authority representing both Turkish and Greek Cypriot people on the Island. Turkey recognises the Turkish Republic of Northern Cyprus (TRNC). Until a lasting and equitable solution is found within the context of the United Nations, Turkey shall preserve its position concerning the "Cyprus issue".

2. Note by all the European Union Member States of the OECD and the European Union: The Republic of Cyprus is recognised by all members of the United Nations with the exception of Turkey. The information in this document relates to the area under the effective control of the Government of the Republic of Cyprus.

Source: http://ec.europa.eu/energy/renewables/targets_en.htm.

13. These include Algeria, Bangladesh, China, Egypt, Ghana, Jamaica, Kuwait, Libya, Morocco, Rwanda, South Africa, Sri Lanka, Thailand, Tonga, Tunisia, and Viet Nam. 
Table A.2. Renewable-energy targets in Latin America and the Caribbean

\begin{tabular}{|c|c|c|c|c|c|c|c|c|c|c|c|c|c|c|}
\hline \multirow[t]{2}{*}{ Country } & \multirow[t]{2}{*}{ Metric } & \multicolumn{13}{|c|}{ Renewable energy share in target year } \\
\hline & & 2012 & 2013 & 2014 & 2015 & 2016 & 2017 & 2018 & 2019 & 2020 & 2021 & 2022 & 2023 & 2024 \\
\hline Argentina & Electricity generated & & & & & $8 \%$ & & & & & & & & \\
\hline Brazil & $\begin{array}{l}\text { Installed electricity capacity } \\
\text { from NCRE }\end{array}$ & & & & & & & & $13 \%$ & & & & & \\
\hline Chile & $\begin{array}{l}\text { Electricity generated from } \\
\text { non-conventional } \mathrm{RE}^{1}\end{array}$ & $5.0 \%$ & $5.0 \%$ & $5.0 \%$ & $5.5 \%$ & $6.0 \%$ & $6.5 \%$ & $7.0 \%$ & $7.5 \%$ & $8.0 \%$ & $8.5 \%$ & $9.0 \%$ & $9.5 \%$ & $10 \%$ \\
\hline Colombia & $\begin{array}{l}\text { Electricity generated, } \\
\text { excluding large hydro }\end{array}$ & & & $3.5 \%$ & & & & & & $6.5 \%$ & & & & \\
\hline Costa Rica & Electricity generated & & & & & & & & & & $100 \%$ & & & \\
\hline Ecuador & $\begin{array}{l}\text { Electricity generated from } \\
\text { large hydro }\end{array}$ & & & & & & & & & $80 \%$ & & & & \\
\hline Ecuador & $\begin{array}{l}\text { Electricity generated from } \\
\text { non-large-hydro RE }\end{array}$ & & & & & & & & & $10 \%$ & & & & \\
\hline Mexico & Installed electricity capacity & $7.6 \%$ & & & & & & & & & & & & \\
\hline Peru & $\begin{array}{l}\text { Electricity generated, } \\
\text { excluding large hydro }\end{array}$ & & $5 \%$ & & & & & & & & & & & \\
\hline St. Lucia & Electricity generated & & $5 \%$ & & $15 \%$ & & & & & $30 \%$ & & & & \\
\hline $\begin{array}{l}\text { St. Vincent \& } \\
\text { Grenadines }\end{array}$ & Electricity generated & & & & $30 \%$ & & & & & $60 \%$ & & & & \\
\hline \multirow[t]{2}{*}{ Uruguay } & $\begin{array}{l}\text { Primary energy, including } \\
\text { from large hydro }\end{array}$ & & & & $50 \%$ & & & & & & & & & \\
\hline & $\begin{array}{l}\text { Electricity generated from } \\
\text { NCRE }\end{array}$ & & & & $30 \%$ & & & & & & & & & \\
\hline
\end{tabular}


The EU member countries and sub-national units in most federal countries are free to implement different incentive measures (feed-in tariffs, premiums, or renewable quota obligations) to reach their targets. A renewable quota obligation for specific renewable technologies is one of the incentive measures that can be implemented at the national or state level, in addition to general renewable mandates. Currently, there are nine OECD member countries $^{14}$ that have national quota obligations in place (ECOFYS, 2011). Korea's national quota system replaced its previous feed-in-tariff system for renewable energy, starting 1 January 2012. In addition, quota obligations have been established by sub-national units in Belgium, Canada and the United States. ${ }^{15}$

There are different design options for national quota-obligation systems. First, obligated actors (the bodies in which the renewable-energy purchase obligation is placed) must be defined. In many cases, the actor is a retail electricity supplier (a utility), but in some cases, the obligation may be imposed on producers or consumers of electricity and heat. Second, governments choose eligible resources for obligated actors to meet their obligation. Some countries include all renewable-energy technologies, while others choose to exclude some from the obligation system. In addition to the choice of technology, some quota systems include small applications - typically hydro-electricity — of the same technology while others impose a specific application size limit for eligibility. These limitations might favour some technologies or sizes before the others. In order to avoid this situation, some countries have introduced two separate quota systems for large and small-scale applications. In 2010, for instance, Australia introduced two different targets for large and small-scale applications in order to provide greater certainty for households and large-scale renewable-energy projects.

Quota obligations are commonly combined with renewable-energy certificates (RECs), which are usually tradable. These certificates are called 'tradable green certificates' in Europe and 'renewable energy credits' in the United States. Among OECD countries, Australia, Belgium, Italy, ${ }^{16}$ Poland, Sweden are the main examples where quota obligation and renewable-energy certificate policies work together. Sweden introduced tradable renewable electricity certificates (RECs) in 2003 and, since then, renewable-energy investors have received RECs valid for 15 years.

RECs are usually traded between renewable energy producers and electricity suppliers (utilities or other agents in the electricity market) and add flexibility by enabling actors with quota obligations to sell credits if they are in surplus, or to buy credits to meet their obligations. Generally, certificates are allocated to producers of renewable energy according to the electricity they generate. Electricity suppliers have to prove that they have met their obligations by showing regulators that they have certificates equal to or exceeding their obligation. The price of these certificates is defined by demand and supply. When there is a certificate shortage, their price rises; their price falls when there is a surplus. The obligation thus creates an opportunity for renewable-energy producers to sell certificates in addition to the revenues they earn from selling electricity to the electricity grid at market prices.

14. Australia, Chile, Italy, Japan, Korea, Poland, Portugal, Sweden, and the United Kingdom.

15. Specifically, by the regional governments of Flanders and Wallonia in Belgium; by British Colombia, Nova Scotia, Ontario, and Prince Edward Island in Canada; and by the State of California in the United States.

16. In 2012, Italy announced that, starting in 2013, all new renewable capacity in the country will be incorporated into a new feed-in tariff programme. From 2015, Italy's manager of electricity services, Gestore dei Servizi Energetici (GSE), will cease buying green certificates and electric utilities will be freed from the purchase mandates of the country’s RPS policy (Gipe, 2012). 
In REC-based systems, renewable-energy producers are exposed to volatility in both the electricity and the renewable certificate markets. Although this situation might increase financial risks for renewable-energy investors, and have negative impacts on willingness to invest in new projects, experiences in Sweden and Australia have demonstrated that a RECbased system can stimulate investment in new renewable-energy generating capacity if the certificates are allocated in connection with long-term contracts.

RECs are usually technology-neutral. In other words, they do not take into account the cost differences of various renewable energy technologies. This can disadvantage less mature technologies, such as solar photovoltaic (PV) power, and advantage more mature technologies, such as onshore wind turbines and biomass combustion. The REC system in Sweden, for instance, over-compensated biomass-fired power plants, a mature technology, while solar PV has not experienced significant deployment (IPCC, 2011b).

In order to avoid such market outcomes, technology-specific certificates have lately been introduced in Belgium, Italy, and the United Kingdom for solar PV. In the United Kingdom, for instance, the technology-banding option provides two certificates for one $\mathrm{MWh}$ of electricity generated by solar PV. Some countries with a quota obligation system provide additional support, such as tax incentives, technology-specific minimum prices or feed-in premiums, in order to help the deployment of less-mature technologies. For instance, Belgium offers minimum prices for solar PV-generated electricity, Italy uses an additional feed-in premium for solar PV, and the United Kingdom has introduced feed-in tariffs for small-scale solar PV applications with a capacity below $5 \mathrm{MW}$.

In OECD countries, quota obligations and RECs operate mainly at the national or subnational level, hence international trading in RECs has been very limited. The notable exception is a bilateral agreement between Norway and Sweden that established a joint market for green certificates on 1 January 2012. In general, quota systems with TRECs aim to stimulate the production of electricity from renewable-energy sources within national borders. The possible harmonisation of national REC-based systems has been discussed at the EU level since 2004. However, the EU's Communication on this issue has concluded that, although harmonisation of support schemes remains a long-term goal, it is not appropriate in the short-term. Rather, it has pointed out that, by adopting best practices or combining national support schemes, its Member States could continue to reform, optimise and coordinate their efforts to support renewable electricity. ${ }^{17}$

\section{Feed-in tariffs and premiums}

Feed-in tariffs (FITs) and premiums are price-driven incentives for the production of electricity from renewable energy sources (RES). Normally they are a form of cross-subsidy, designed to encourage investment in clean and low-carbon electricity and generation, in most cases without placing a cap or quota on the amount of electricity or heat generated. They offer a guaranteed price or premium for a long period for each unit of electricity or heat fed into the grid produced from an RES. This long-term purchase guarantee lowers investment and capital risk, while guaranteeing connection to the network. Priority access and dispatch further reduce risks because investors are assured a market for the electricity they produce. The FIT and premium payments are usually managed by utilities or grid operators where they are legally obligated to pay the fixed price per unit of electricity generated by the RES. Feed-in tariffs differ from net metering, which is a simplified mechanism for giving electricity consumers credit for electricity they generate themselves (Box 2).

17. See Commission document (SEC (2008)578) of 23 January 2008. 


\section{Box 2. Net metering}

One common, and quick-to-implement, policy that governments in several OECD countries have used to promote greater diffusion of small-scale, distributed electricity generation from renewable energy is to require electric companies to allow customers (typically, households or small businesses) to engage in what is called "net metering". This policy does not involve a direct financial incentive from the government, but it is often combined with other financial incentives, and may provide a benefit to the consumer-generator greater than what he or she would otherwise obtain in the absence of the policy.

The basic idea is that when a home, school or commercial building is equipped with a renewable-energy-based electrical power source (such as a solar photovoltaic array or a small-scale wind turbine) it can send the excess energy that is generated back into the electricity grid. As that excess energy is being generated, the customer-generated electricity meter spins backward rather than forward, giving it a credit that can be used to offset the electricity taken from the grid at other times. In many service areas, customer-generators are allowed to roll over any excess electricity generated during one billing period to the next one, just as many cell phone companies let customers roll over un-used minutes from one billing period to the next.

Currently, net metering is most prevalent in the United States, owing to the Energy Policy Act of 2005, which required all public electric utilities to make available upon request net metering to their customers. All but a handful of US states have since implemented net metering; several municipalities have also established their own regulations. The US Energy Information Administration (USEIA, 2012) estimates that by the end of 2011 there were $2.7 \mathrm{GW}$ of (mostly solar PV) generating resources linked to the grid through net metering in the United States, spread across more than 200000 residential customers, 19500 commercial customers, and 4500 industrial customers. Net metering is available as well in two Australian states (Queensland and Victoria), eight Canadian provinces (British Columbia, Saskatchewan, Manitoba, Ontario, Quebec, New Brunswick, Nova Scotia, and Prince Edward Island), and in four EU Member States (Denmark, France, Italy, and Spain). When separate meters are used to measure imports from and exports to the grid (often so as to vary the price paid for power according to when it is delivered), the terms "net billing" or "net purchase and sale" are often used. Several countries (e.g., Germany, Jamaica), a few US states, and the Canadian Provinces of Alberta and Ontario offer net billing.

The rules of net metering vary significantly by jurisdiction, especially with regard to: the maximum peak power that may be fed back into the grid (among the different United States, for example, it ranges from $25 \mathrm{~kW}$ to $1000 \mathrm{~kW}$ or more); the number of months that consumergenerators can bank their credits; and how much the credits are worth. Typically, if at the end of a specified period (e.g., a year), the customer generates more electricity than he or she had the need for, the electric company will pay for that surplus power. Some electric utilities pay the avoided cost or wholesale electricity rate for surplus credits, some the retail price of electricity, and some an even higher, fixed price. The latter approach is essentially analogous to a feed-in tariff.

Net metering is championed by many promoters of distributed production of renewable energy because it is relatively easy and inexpensive to implement. It enables small-scale investors in renewable-energy equipment to earn money (or at least reduce their electricity bill) from any excess electricity they produce, without having to install a second meter or an expensive battery-storage system. Critics argue that paying for or crediting electricity exported by consumer-generators at the retail price of electricity in effect over-compensates consumer-generators, especially if their power output does not coincide with peak system demand, and that it shifts some of the burden of recovering the transmission, distribution, and other fixed costs that are embedded in average retail $\mathrm{kWh}$ rates to other customers (Churchill, 2013). For that reason some prefer net billing, which can be set up to more accurately account for the avoided cost of the power generated over different times of the day.

Sources : PV Magazine (2013), USEIA (2012); Churchill (2013). 
Utilities normally pass on to consumers the additional cost that they pay above the market price of electricity. Some consumers can be exempt from this surcharge on their electricity bills. In Germany, for instance, heavy industry is exempt from the renewable energy surcharge. In Japan, so are some industrial commercial consumers ${ }^{18}$ of electricity whose offices, production facilities or business equipment were severely damaged after the Great East Earthquake. In addition to industrial users, some low-income households are also exempt from renewable-energy surcharges in many developing countries. Also, some states in the United States provide a "renewable energy surcharge credit" for certain consumers. ${ }^{19}$ However, there are a few remuneration models where governments directly subsidise part or all of the market premium, thereby shifting the additional cost of renewable energy from ratepayers to taxpayers. ${ }^{20}$

FITs and feed-in premiums are the most common support measures used in OECD countries. In Europe, FITs were initially introduced in the late 1980s in Denmark, Germany, Italy, and in the 1990s in Spain. Nowadays they are the most widely used promotion instrument in Europe. Some seventeen European countries have some sort of FIT or feed-in premium policy. FITs are also used in several Canadian Provinces and in some states in the United States (IEA, 2013).

FITs are usually differentiated by technology type and size of installation (e.g. industrial scale or attached to individual homes). According to our survey of the literature, only the US State of Louisiana has implemented an undifferentiated FIT. It offers a limited contract term of five years, and covers only projects up to $5 \mathrm{MW}$ (DOE, 2013a). Generally, governments estimate the levelised cost of electricity (LCoE) for different renewable-energy technologies, and design the FIT rates accordingly. FITs are usually higher for more expensive technologies, such as solar PV, and lower for mature technologies, such as hydro-electric and onshore wind plants. However, similar technologies benefit also from very different FITs across countries (Tables A.3 and A.4).

Some technology-specific FITs are fixed over the life of the contract, while others vary over time. China, for instance, employed a fixed-price FIT model while some governments, such as those of Ontario (Canada), France, Ireland, and Spain, adjust their FITs annually with inflation. The Ukraine expresses its FITs in its local currency, the hyrvnia, but adjusts them on a monthly basis according to fluctuations in the euro-hyrvnia exchange rate. Some other countries have implemented FITs that decline over time: Germany is an example of a country offering higher tariffs in the early years of investment than in the later years. This differentiation reflects the declining financial costs that an investor has to pay over the life-

18. Some industrial users are entitled to a reduction of $80 \%$ of more depending on the ratio of their electricity consumption (in $\mathrm{kWh}$ ) per sales volume (per JPY 1000 ). If an industrial consumer uses eight times more electricity than the average ratio of electricity consumption to sales volume, it will be fully or partly exempted from the surcharge according to the regulation.

19. In the US State of Michigan, for instance, taxpayers may claim the credit if the surcharge appears on their monthly electric utility bill. To be eligible for this credit, the adjusted gross income (AGI) must be no more than USD 65000 for single people and married couples filing separately, or USD 130000 for married couples filing jointly.

20. In some countries, ratepayers and taxpayers share the burden of this additional cost. In Spain, for instance, the government subsidises the additional cost partially in order to prevent retail electricity prices from increasing - leading to a need for higher taxes instead. The FIT model in the Netherlands is called the spot market gap model. In this model, the actual FIT payment is comprised of the gap between the spot market price and the required FIT price. Instead of the added marginal cost being passed on the electricity customers, it is covered by a government subsidy. 
time of the project. The FIT in Slovenia drops by $5 \%$ after the $5^{\text {th }}$ year, then by $10 \%$ after the $10^{\text {th }}$ year. Malaysia's FITs for biogas- and biomass-fired power plants decline at an annual digression rate of $0.5 \%$; those for electricity generated by solar PV installations, which are offered over 21 years, decline at an annual digression rate of $8 \% .^{21}$ The new renewableenergy law in Japan requires a regular review of its FITs that is supposed to consider several factors, such as the level of penetration by renewable-based electricity; the retail price of electricity and projections for such prices; their impact on individuals, and the burden of surcharges on economic activities; and other changes in domestic and international social and economic conditions.

Table A.3. Indicative feed-in tariff levels for new renewable-electricity plants in OECD countries (EUR/kWh)

\begin{tabular}{|c|c|c|c|c|c|}
\hline Country & $\begin{array}{l}\text { Wind power } \\
\text { (on-shore) }\end{array}$ & $\begin{array}{l}\text { Wind power } \\
\text { (off-shore) }\end{array}$ & $\begin{array}{l}\text { Solar } \\
\text { PV }\end{array}$ & $\begin{array}{c}\text { Solid } \\
\text { biomass }\end{array}$ & $\begin{array}{l}\text { Small } \\
\text { hydro }\end{array}$ \\
\hline Australia & - & - & 一 & - & - \\
\hline Queensland & n.a & n.a & 0.064 & n.a & n.a \\
\hline South Australia & n.a & n.a & 0.128 & n.a & n.a \\
\hline Victoria & n.a & n.a & 0.064 & n.a & n.a \\
\hline Austria & 0.095 & n.a. & $0.190-0.276$ & $0.100-0.150$ & 0.05 \\
\hline $\begin{array}{l}\text { Belgium } \\
\text { (federal only) }\end{array}$ & 0.05 & 0.090 & 0.15 & 0.02 & 0.05 \\
\hline Canada & - & - & 一 & 一 & - \\
\hline Ontario & 0.086 & n.a. & $0.259-0.410$ & $0.097-0.103$ & $0.091-0.098$ \\
\hline Quebec & n.a. & n.a. & n.a. & 0.141 & n.a. \\
\hline Nova Scotia & $0.098-0.375$ & n.a. & n.a. & $(\mathrm{CHP}) 0.132$ & 0.105 \\
\hline Chile & n.a. & n.a. & $\mathrm{n} / \mathrm{a}$ & n.a. & $\mathrm{n} / \mathrm{a}$ \\
\hline Czech Republic & $0.082-0.108$ & 0.108 & 0.45 & $0.077-0.103$ & 0.081 \\
\hline Denmark & 0.037 & up to 0.083 & $0.054-0.080$ & 0.020 & n.a \\
\hline Estonia & 0.051 & 0.051 & 0.073 & 0.051 & 0.051 \\
\hline Finland & $0.0835-0.0902$ & n.a. & n.a. & n.a. & n.a. \\
\hline France & 0.082 & n.a. & $0.0818-0.3475$ & 0.125 & 0.06 \\
\hline Germany & $0.05-0.089$ & 0.15 & $0.1178-0.1702$ & $0.06-0.143^{3}$ & $0.042-0.127$ \\
\hline Greece & $0.07-0.09$ & $0.07-0.09$ & $0.40-0.55$ & $0.07-0.08$ & $0.07-0.08$ \\
\hline Hungary & 0.095 & n.a. & .. & n.a. & $0.029-0.052$ \\
\hline Iceland & n.a. & n.a. & n.a. & n.a. & n.a. \\
\hline Ireland & 0.059 & 0.059 & $\mathrm{n} / \mathrm{a}$ & 0.072 & 0.072 \\
\hline Israel & $0.24-0.31\left(^{1}\right)$ & n.a. & 0.40 & - & - \\
\hline Italy & $0.127-0.291$ & $0.205-0.216\left(^{2}\right)$ & $0.135-0.288$ & $0.110-0.257$ & $0.096-0.257$ \\
\hline Japan $^{4}$ & $0.190-0.474$ & n.a. & $0.345-0.394$ & $0.112-0.336$ & $0.207-0.293$ \\
\hline
\end{tabular}

21. www.mbipv.net.my/dload/FAQs\%20on\%20FiT.pdf. 
DOMESTIC INCENTIVE MEASURES FOR RENEWABLE ENERGY WITH POSSIBLE TRADE IMPLICATIONS

\begin{tabular}{|c|c|c|c|c|c|}
\hline Country & $\begin{array}{l}\text { Wind power } \\
\text { (on-shore) }\end{array}$ & $\begin{array}{l}\text { Wind power } \\
\text { (off-shore) }\end{array}$ & $\begin{array}{l}\text { Solar } \\
\text { PV }\end{array}$ & $\begin{array}{c}\text { Solid } \\
\text { biomass }\end{array}$ & $\begin{array}{l}\text { Small } \\
\text { hydro }\end{array}$ \\
\hline Korea $^{5}$ & 0.072 & n.a. & 0.49 & n.a. & 0.051 \\
\hline Luxembourg & $0.08-0.10$ & $0.08-0.10$ & $0.28-0.56$ & $0.103-0.128$ & $0.079-0.103$ \\
\hline Mexico & n.a. & n.a. & n.a & n.a. & n.a. \\
\hline Netherlands & 0.118 & 0.186 & $0.32-0.40$ & $0.115-0.177$ & $0.073-0.125$ \\
\hline New Zealand & n.a. & n.a & n.a & n.a. & n.a. \\
\hline Norway & n.a. & n.a & n.a & n.a. & n.a. \\
\hline Poland & 0.157 & n.a. & 0.265 & 0.038 & 0.169 \\
\hline Portugal & 0.074 & n.a. & $0.257-0.47$ & 0.119 & 0.075 \\
\hline Slovakia & $0.05-0.09$ & n.a. & 0.45 & $0.072-0.10$ & $0.066-0.10$ \\
\hline Slovenia & $0.087-0.094$ & n.a. & $0.267-0.414$ & $0.074-0.224$ & $0.077-0.105$ \\
\hline Spain $^{6}$ & 0.073 & n.a. & $0.32-0.34$ & $0.107-0.158$ & 0.077 \\
\hline Sweden & n.a. & n.a. & n.a. & n.a. & n.a. \\
\hline Switzerland & $0.055-0.125$ & n.a. & $0.39-0.61$ & $0.095-0.011$ & \\
\hline Turkey & $0.055-0.075$ & n.a. & $0.095-0.14$ & n.a. & $0.05-0.067$ \\
\hline United Kingdom & $0.051-0.241$ & 0.37 & $0.082-0.177$ & 0.12 & $0.051-0.241$ \\
\hline \multicolumn{6}{|l|}{ United States } \\
\hline Gainesville, FL & n.a. & n.a. & 0.25 & n.a. & n.a. \\
\hline Hawaii & $0.106-0.124$ & n.a. & $0.183-0.211$ & n.a. & $0.145-0.164$ \\
\hline Rhode Island & $0.114-0.190$ & n.a. & $0.192-0.230$ & n.a. & n.a. \\
\hline Vermont & $0.087-0.188$ & n.a. & 0.208 & 0.093 & 0.091 \\
\hline Wisconsin & $0.054-0.062$ & n.a. & 0.085 & $0.062-0.066$ & n.a. \\
\hline
\end{tabular}

1. Only for small applications from $1 \mathrm{~kW}$ to $50 \mathrm{Kw}$.

2. Including a premium of EUR 0.04 per kWh.

3. Bonuses of up to EUR 0.08 may be given in addition depending on size of plant and type of biomass used.

4. Inclusive of the consumption tax, which at the beginning of 2013 was $5 \%$.

5. For existing plants only; in 2012 Korea replaced its feed-in tariff system with a renewable portfolio standard, hence new projects do not benefit from FITs.

6. On 27 January 2012, the Spanish government suspended accepting new FiT applications for projects beginning operation after January 2013. The FITS shown reflect those available at the time of the suspension.

Note: Feed-in tariffs for each technology vary due to maximum and minimum levels provided by governments according to sizes of application, and in the case of bio-energy in some cases by the type of feedstock used, or whether waste heat is recovered. Feed-in tariffs are also subject to frequent change, and may be different for different vintages of plants. This table should therefore be treated as indicative only; for actual values at any given point in time, readers are advised to check each government's official web sites.

Sources: IEA Renewable Energy Database; Wind Works (http://energyindemand.com/2013/02/27/reviewing-feed-in-tariffs/); Database of State Incentives for Renewables \& Efficiency (www.dsireusa.org); PV Magazine (www.pvmagazine.com/services/feed-in-tariffs/feed-in-tariffs-for-various-countries/). 
Table A.4. Feed-in tariff levels in selected non-OECD countries

(USD/kWh)

\begin{tabular}{|c|c|c|c|c|c|}
\hline Country & $\begin{array}{l}\text { Wind power } \\
\text { "On-shore" }\end{array}$ & $\begin{array}{l}\text { Wind power } \\
\text { "Off-shore" }\end{array}$ & Solar PV & Biomass & Hydropower \\
\hline Argentina & 0.025 & n.a. & 0.15 & 0.025 & 0.025 \\
\hline Brazil & 0.097 & n.a. & & 0.044 & 0.054 \\
\hline Bulgaria & $0.075-0.096$ & n.a. & $0.35-0.38$ & $0.061-0.217$ & $0.057-0.113$ \\
\hline China & $0.051-0.062$ & n.a. & $0.11-0.13$ & 0.039 & $\mathrm{n} / \mathrm{a}$ \\
\hline Ecuador & 0.070 & n.a. & 0.308 & $0.074-0.085$ & $0.048-0.055$ \\
\hline India & $0.052-0.078$ & n.a. & 0.22 & $\mathrm{n} / \mathrm{a}$ & $\mathrm{n} / \mathrm{a}$ \\
\hline Malaysia & $\mathrm{n} / \mathrm{a}$ & n.a. & $0.28-0.62$ & $0.0 .9-0.11$ & 0.08 \\
\hline Malta & $\mathrm{n} / \mathrm{a}$ & n.a. & $0.26-0.36$ & $\mathrm{n} / \mathrm{a}$ & $n / a$ \\
\hline $\begin{array}{l}\text { South } \\
\text { Africa }\end{array}$ & 0.11 & n.a. & 0.36 & 0.108 & 0.086 \\
\hline Thailand & $0.034^{1}$ & n.a. & $0.034^{1}$ & $0.006-0.010^{1}$ & $n / a$ \\
\hline Ukraine & $\mathrm{n} / \mathrm{a}$ & n.a. & $\sim 0.43$ & $\mathrm{n} / \mathrm{a}$ & $n / a$ \\
\hline
\end{tabular}

1. Premium on top of prevailing electricity prices.

Note: Feed-in tariffs for each technology vary due to maximum and minimum levels provided by governments according to sizes of application.

Source: IEA Renewable Energy Database (2013); PV Magazine (www.pv-magazine.com/services/feed-in-tariffs/feedin-tariffs-for-various-countries/).

Whether fixed or dynamic, FITs attract investors as long as the tariff is set at a level that meets the investors' needs. Thus the setting of FIT rates requires considerable care. Setting them too high can lead to windfall profits; setting them too low may not attract the desired renewable-energy investments. For instance, the FIT offered in Turkey since 2005 has been, in general, lower than the average electricity prices in the spot market and has attracted less investment than policy makers were seeking. The opposite situation happened in the Czech Republic, Italy and the United Kingdom in 2010 and 2011, where these countries slashed FIT rates for solar PV once it was discovered that producers were earning windfall profits. Spain also changed its FIT retroactively by cutting the incentive provided to large-scale groundmounted PV systems by $45 \%$ and to medium-size installations by $25 \%$ for ongoing projects, and suspended the FIT for newly installed RE generators.

Another variation of a FIT is a feed-in premium. Among the OECD member countries, Denmark, Italy, and Netherlands use mainly feed-in premiums. The US federal production tax credits for electricity generated from certain renewable-energy sources can also be considered as a form of feed-in premium, albeit financed by taxpayers rather than rate payers. Under this kind of policy, the generator of renewable energy receives the premium on top of the market price of electricity, which typically changes hour by hour. The advantage of premiums is that they encourage producers to adjust output in response to market price signals. In premium systems, the renewable-energy producers participate actively in wholesale electricity market operations. With a premium, the generator's revenue is less predictable than with a fixed price FIT because it varies along with the electricity price. Some premiums therefore are limited by a floor price or cap, or both. This design provides higher certainty and less risk of overcompensation. In order to create some flexibility for renewable-energy developers, some countries, such as the Czech Republic, Slovenia, and Spain, offer both a fixed-FIT and a premium to investors, leaving them to choose the most suitable one for their project.

Production-based tax incentives are measures that provide the producers a per-kilowatthour tax incentive for the electricity generated by qualified renewable-energy sources. These 
incentives are usually offered in the form of tax credits and exemptions from income tax, and apply to both commercial and household applications. Production tax incentives have a similar effect on production as feed-in premiums, but are paid by taxpayers. The United States federal production tax credit (PTC), allows producers of electricity from qualifying renewable-energy plants to obtain an income-tax credit at a set rate per unit of renewable electricity produced. The tax credit differentiates among two broad categories of renewableenergy technology. ${ }^{22}$ In some countries, such as the Slovak Republic and the United Kingdom, production tax incentives are technology-neutral. Although some countries offer production-tax incentives for all renewable-energy technologies (some in a technology-neutral fashion, some not), others target a specific renewable-energy source. Luxembourg, for instance, uses the personal income tax to promote electricity generated from solar PV installations only.

In some cases, FITs come with domestic-content requirements (DCRs). These provisions are usually introduced to increase domestic manufacturing, create local employment opportunities, and encourage technology transfer. Some governments implement absolute DCRs by obliging companies to use locally manufactured machines (fully or partially) in order to become eligible for the FIT that they offer. One of the oldest is that instituted by Argentina's Province of Chubut. In 1999 the Province introduced a renewable-energy law which required that $10 \%$ of the components in wind parks that had begun operating in 1999 be manufactured or assembled locally. The DCR increased to $30 \%$ for those wind parks operating from 2001 , then to $60 \%$ (2003), $80 \%$ (2005) and finally $100 \%$ (since 2007). ${ }^{23} \mathrm{In}$ Canada, the FIT programme of Ontario requires developers of wind and solar installations benefiting from the FIT to have 50\% (for solar projects of over $10 \mathrm{MW}$ ) to $60 \%$ (for solar projects of $10 \mathrm{MW}$ or less) of their project costs incurred in Ontario. ${ }^{24}$ However, following a recent ruling by the WTO's Dispute Settlement Body, Ontario announced it would eliminate the DCR (Timmins and Blumer, 2013). Québec's regulations stipulate that $60 \%$ of the wind turbines' costs must be incurred in the province and 35\% in the Gaspé Peninsula (PICS, 2010).

The Ukraine has recently introduced one of the most extensive systems of DCRs for renewable-energy in the world, covering multiple technologies (those based on wind energy, solar energy, biomass, biogas, and hydropower). In order for renewable-energy facilities coming into operation in 2012 to qualify for a FIT, at least $15 \%$ of the aggregate value of raw materials, equipment, and services had to be sourced from the Ukraine. This rate increased to a minimum of $30 \%$ for facilities commissioned after 1 January 2013, and will rise to 50\% for

22. The tax credits were extended by the American Taxpayer Relief Act of 2012 (H.R. 6, Sec. 407) until the end of 2013 for facilities on which construction will have begun by the end of 2013 . They provide USD 0.022 per $\mathrm{kWh}$ produced by facilities powered by wind or geothermal energy, and closed-loop technologies powered by biomass; the tax credits are half that amount (USD 0.011 per $\mathrm{kWh}$ ) for other eligible technologies (open-loop biomass, municipal solid waste, qualified hydroelectric facilities, and marine (tidal energy, wave energy, ocean thermal power) and hydrokinetic power plants (i.e. plants that generate electricity from flowing water) of $0.15 \mathrm{MW}$ capacity or larger). See http://www.dsireusa.org/.

23. http://organismos.chubut.gov.ar/cree/files/2010/03/Ley_Eolica_Chubut1.pdf.

24. On 13 September 2010, Japan launched a complaint at the World Trade Organization (WTO) arguing that the domestic-content requirements under the Ontario FIT program violate international trade laws. A similar complaint was lodged by the European Union on 11 August 2011. The panel report on these disputes was released on 19 December 2012 (see WTO document WT/DS412R and WT/DS426R). The Appellate Body report, which found the DCR in Ontario's FIT Program to be inconsistent with the TRIMS Agreement and GATT 1994, was issued on 6 May 2013 and on 24 May 2013 the DSB adopted the report. 
facilities commissioned after 1 January 2014 (McKenna et al., 2012). The Ukraine's National Electricity Regulatory Commission is responsible for confirming the amount of domestic content in qualifying facilities.

In addition to absolute DCRs, some countries have implemented premiums related to domestic content that are provided on top of the base FIT. Turkey's Renewable Energy Law of 2010, for example, offers bonus payments if the hardware components of renewableenergy technologies used to produce the electricity are manufactured in Turkey. In Italy, investors are entitled to an additional $10 \%$ bonus payment for solar components manufactured in the European Union. In January 2013, France introduced a similar measure, providing a 5\% to $10 \%$ premium on its FIT for electricity generated by solar panels; the actual premium is determined by criteria relating to the amount of fabrication or processing undertaken at a production site located within the European Economic Area; the criteria are separately specified for PV modules made of crystalline silicon and thin-film PV modules. ${ }^{25}$ Malaysia offers bonus payments of MYR 0.01 (USD 0.0033) per kWh on top of its feed-in tariffs if the biomass or bio-energy plants use locally manufactured or assembled gas engine or gasification technologies. It adds MYR 0.03 (USD 0.01) per kWh to its feed-in tariffs for solar-PV-generated electricity if the plants use locally manufactured or assembled solar-PV modules; if they use locally manufactured or assembled solar inverters, they qualify for an additional MYR 0.01 (USD 0.0033) per $\mathrm{kWh}^{26}$ In the United States, the state of Washington provide a production incentive for solar PV generated electricity that increases if consumers use locally-produced solar panels or invertors. If both solar inverters and modules are locally manufactured, the base incentive rate almost triples (DOE, 2013a).

In some other cases, DCRs are not explicit in FITs, but are included as a requirement in renewable-energy tenders and procurements. In the United States, the procurement of PV devices by the Secretary of Defence requires that the devices provided under contract comply with the Buy American Act. ${ }^{27}$ Some countries design tenders for renewable energy that include domestic-content and industrial-cluster-development requirements. For example, the requirement related to "creation of industrial cluster" accounts for a total of $45 \%$ of the evaluation scoring in the $1500 \mathrm{MW}$ onshore wind tender opened in 2006 by the Portuguese government. The Spanish provinces of Galicia, Navarra, Castile, Leon, and Valencia, at one point, required the local manufacturing of turbines and components, as well as local assembly, before granting eligibility for development concessions. China formerly demanded up to $70 \%$ DCRs for its wind concessions in the Provinces of Jiangsu, and Jilin, and the autonomous region of Inner Mongolia.

Some countries or electric utilities procure new generating capacity or electricity, or both, through auctions. ${ }^{28}$ The resulting electricity tariff paid to winning bidders is then typically fixed for a defined period. The Brazilian state, through its main electricity regulator, Agência

25. Www.legifrance.gouv.fr/affichTexte.do?cidTexte=JORFTEXT000027008908.

26. www.mbipv.net.my/dload/FAQs\%20on\%20FiT.pdf.

27. Bill H.R. 6523.IH, 111th Congress (2009-2010), Ike Skelton National Defense Authorization Act for Fiscal Year 2011, SEC. 846. "PROCUREMENT OF PHOTOVOLTAIC DEVICES. Contract Requirement - The Secretary of Defense shall ensure that each contract described in subsection (b) awarded by the Department of Defense includes a provision requiring the photovoltaic devices provided under the contract to comply with the Buy American Act (41 USC. 10a et seq.), subject to the exceptions to that Act provided in the Trade Agreements Act of 1979 (19 USC. 2501 et seq.) or otherwise provided by law."

28. Those that have held auctions specifically for renewable-energy-based generating capacity or electricity include Brazil, China, Egypt, Peru, Thailand, Uruguay, the Canadian province of Ontario, and the US State of California. See the study by Maurer and Barroso (2011). 
Nacional de Energia Elétrica (ANEEL), for example, has held 15 power-supply auctions since June 2005. The current plan is to stop building new power plants fuelled by petroleum after 2015; plants powered by wind and biomass are expected to be the main beneficiaries.

ANEEL's aim is to boost installed wind-power generating capacity to $11.5 \mathrm{GW}$ by tendering at least $2 \mathrm{GW}$ per year until the 2020 objective is met. In 2009 Brazil held its first wind-only auction (Castano, 2011); during the government auction that took place in August 2011, $1 \mathrm{GW}$ was awarded to the state-owned power firm Eletrosul and another $1 \mathrm{GW}$ to five companies, three of which were Brazilian, plus the Italian company, Enel and the Spanish company, Iberdola (Agencia EFE, 2011). In December 2012 the Brazilian Federal Government held its A-5/2012 Energy Auction, in order to meet the projected electricity demand in the year 2017. Twelve power-generation projects were contracted - two hydroelectric (for a cumulative total of $292.4 \mathrm{MW}$ ) and ten based on wind power (rated at 281.9 MW). The average price awarded was BNL 93.46 per MWh (USD 0.047 per $\mathrm{kWh}$ ) for hydroelectricity and BNL 87.94 per MWh (USD 0.045 per $\mathrm{kWh}$ ) for wind-generated power $-18.5 \%$ lower than offered during the first auction - over contract periods of, respectively, 30 and 20 years. ${ }^{29}$ The main winner of the wind auction was the Brazilian company, Bioenergy (accounting for more than two-thirds of installed capacity), followed by EGPSerra Azul, Enerfin Sociedad de Energia SA (a Spanish company), and Renova. ${ }^{30}$ Most of the turbines will be installed in Brazil's windy northeast regions of Bahia, Ceara, Maranhao, Rio Grande do Norte, and Sergipe, with the rest in southern Brazil.

Developers of electricity projects in Brazil often procure long-term credit from the Brazilian National Economic Development Bank (Banco Nacional de Desenvolvimento Economico e Social, or BNDES), through a financing programme called BNDES Finame-PSI. The terms of the loans are highly competitive: during 2013, the interest rate available for new projects will be $5.5 \%$ per annum, with a repayment term of up to 30 years and a grace period of up to nine years (Brazil, Ministério da Fazenda, 2012). By contrast, as of January 2013 the average interest rate on loans from commercial banks for financing capital goods was more than twice the BNDES rate. ${ }^{31}$ There is a condition on obtaining BNDES loans for wind-power projects, however. As of the beginning of 2013, developers seeking to buy wind turbines for their projects can obtain the concessional rates from the BNDES only if they procure the turbines from companies that comply with new domestic-content rules. These require in turn that the wind-turbine manufacturers source at least $60 \%$ of their components from Brazilian suppliers, and to produce or assemble some of the main elements of the turbines within the country. (A method for verifying and accrediting the domestic content of wind turbines was published in December 2012. ${ }^{32}$ ) Several foreign turbine manufacturers have since said that they may have to raise their prices in Brazil by as much as $20 \%$ in order comply with these conditions (Nielson, 2013).

In India, the Jawaharlal Nehru National Solar Mission (NSM) uses a competitive bidding process for new solar-powered electricity. However, project developers have to meet a DCR (around 60\% for solar PV and 30\% for solar thermal) in order to be eligible for the 25 years power purchase agreement with a fixed feed-in tariff. Under the first phase (FY 2012-13) of

29. www.epe.gov.br/imprensa/PressReleases/20121214_1.pdf

30. www.epe.gov.br/leiloes/Documents/Leil\%C3\%A3o\%20A-5\%202012/Resultado\%20\%20Lei1\%C3\%A3o\%20de\%20Energia\%20A-5\%202012.pdf.

31. www3.bcb.gov.br/sgspub/localizarseries/localizarSeries.do?method=prepararTelaLocalizarSeries. 
the NSM, PV modules incorporating thin-film technology are exempted from the $60 \%$ DCR, while projects using PV panels with crystalline silicon (cSi) technology are required to source $60 \%$ of their components locally. However, since October 2012, solar PV projects qualifying under the "Off-grid and Decentralized Solar Applications" scheme ${ }^{33}$ cannot use imported equipment: only indigenously manufactured PV modules can qualify for the support, which provides a capital subsidy of $90 \%$ of the benchmark cost for solar PV power projects having a module capacity of up to $100 \mathrm{~kW} .^{34}$

Uruguay, which has also auctioned new renewable-energy generating capacity, includes stipulations in its tenders that suppliers benefitting from its FITs must include a minimum of $20 \%$ equity participation by a local partner, and contract $80 \%$ of subsequent maintenance locally (Boscoe, 2010). In Korea, the government is planning to invest USD 8.4 billion in a $2.5 \mathrm{GW}$ offshore wind farm. According to Korea's Ministry of Knowledge Economy, the country's three biggest shipyards ${ }^{35}$ will likely bid for manufacturing and installing wind turbines. Overseas companies are not able to bid for tenders.

\section{Incentives for deployment}

In addition to the market-pull support measures mentioned above, many countries use tax incentives to promote the deployment of renewable-energy technologies. These tax incentives take the form of various tax instruments (credits, exemptions, reductions, rebates, and variable or accelerated depreciation) as well as loans, loan guarantees and grants. Governments offer these incentives both for investment in utility-scale generating plants (investment-based incentives) for commercial and household self-generation. Investment-based tax incentives focus on initial or investment costs, whereas production-based tax incentives address operating production costs. These incentives are provided through both direct (personal income tax, corporate tax and property tax) and indirect taxes (VAT, excise-duty exemptions) and are often targeted to specific renewable-energy technologies.

Deployment incentives are usually complementary to other programmes that support renewable energy. ${ }^{36}$ They are also usually granted for relatively shorter periods (2-10 years) than feed-in tariffs, and are often adjusted as technologies and market conditions evolve. Because tax incentives are paid by taxpayers rather than ratepayers, and involve foregone government revenue, they are politically vulnerable.

One way that governments reduce the up-front costs of installing renewable energy is to subsidize, or cross-subsidize, the costs of connecting small renewable-energy plants to the electricity grid. Official figures from China, for example, indicate that $25 \%$ of the power generating capacity of new solar plants installed in that country during 2011 went unused because the plants could not obtain a connection with the grid. Accordingly, in October 2012,

33. Qualifying projects must be installed in one the following "special-category" areas of the country: north-east Sikkim, Jammu and Kashmir, Himachal Pradesh and Uttarakhand; remote and difficult areas such as Lakshadweep, and the Andaman and Nicobar Islands; and districts on India's international borders.

34. Directive No. 5/23//2009-P\&C (Pt. III), http://mnre.gov.in/file-manager/UserFiles/amendmendsaa-jnnsm-2012-13.pdf. The benchmark costs vary by size of the plant, and are further differentiated into whether they include a battery or not. See http://mnre.gov.in/filemanager/UserFiles/amendmends-benchmarkcost-aa-jnnsm-2012-13.pdf.

35. Hyundai Heavy Industries Co., Daewoo Shipbuilding \& Marine Engineering Co., and Samsung Heavy Industries Co.

36. Among OECD member countries, Finland is the only country with production and investmenttax incentives as its principle policy to support the deployment of renewable energy. 
the state-owned, regional power distributor, State Grid Corp, announced that it would start offering free grid connection for small-and-medium-scale solar power producers (He, 2012).

More common are deployment incentives that can be used to support any part of the investment cost of a facility. The majority of OECD countries offer such deployment incentives. In the European Union, these incentives consist mainly of income- and corporatetax deductions, and VAT reductions and exemptions directed at both the production of electricity from renewable energy sources, and investment in generating plants. In the United States at the federal level, they take the form of tax credits. In Australia, the federal government exempts from corporate-gains tax any gains or losses arising from a right to a financial incentive granted to taxpayers under a Commonwealth, State or Territory government scheme that encourages them to deploy solar photovoltaic cells, solar hot-water systems or other "renewable resource assets".

Investment-based tax incentives enable investors in renewable energy to be partially or fully exempted from certain tax obligations. These tax incentives are usually offered to both commercial and household applications. For commercial applications, some countries allow deductions in or exemptions from the corporate income tax for investments in facilities that generate electricity from renewable-energy sources. Others have introduced a reduction in the VAT rate for materials and services used in similar commercial investments. Italy and Portugal, for instance, charge a reduced tax (10\% rather than $20 \%$ for Italy, $12 \%$ rather than $21 \%$ in Portugal), on the purchase of equipment and services related to wind and solar facilities that generate energy. Variable or accelerated depreciation is another incentive that allows companies to receive a reduction in their income tax in the first years of operation of the renewable-energy equipment. This incentive generally applies to commercial entities, and has been implemented in Belgium, Canada, Ireland, the Netherlands and the United Kingdom.

For household applications, France allows consumers to pay a reduced rate of VAT when buying basic products related to improvements, changes and installation in residential buildings that incorporate technologies based on solar and wind power. In some countries, expenses related to renewable-energy investments can be offset against income tax. In Belgium, the amount of reduction is $40 \%$ of the actual costs of the project. In France, households that install renewable-energy systems at their principal residence may deduct a certain amount (11\% in 2012) of the costs of the hardware from their income tax, depending on the equipment used.

Investment-based tax incentives (and also production tax incentives), which are implemented under national tax laws and regulations, differ from country to country in their effective rates of support. A crucial issue determining the extent to which a company can make use of a tax incentive is its tax liability, the rules for which differ from jurisdiction to jurisdiction and depend on a number of complex factors. In the absence of a carry-forward provision, having an insufficient tax liability might limit the ability of foreign suppliers not domiciled in the country, or small- and medium-sized enterprises wherever domiciled, to take advantage of the full value of the incentive or the credit provided. This situation might also indirectly favour larger and more-diversified locally established companies over small foreign or domestic investors.

Tax laws, in general, require the equipment producing electricity or heat from renewableenergy resources to be installed in their jurisdiction. However, additional requirements are sometimes imposed on an investor to be able to make use of accelerated-depreciation provisions. In some countries, certain types of renewable-energy equipment are not included in the list of capital goods that can qualify for accelerated depreciation. The UK list, for example, only includes one category of equipment related to the generation of electricity from renewable energy: equipment used in combined heat and power (CHP) plants that are certified as meeting minimum energy-efficiency standards. The Dutch list only includes only wind- 
energy equipment and solar renewable electricity equipment. In some other countries, the companies entitled to accelerated depreciation for renewable-electricity generation equipment are limited to those that produce electricity for commercial sale, and do not include household applications or companies that produce and consume their own electricity using wind or solar energy.

In addition to tax incentives, some local governments provide additional incentives for small applications so that households can afford renewable energy technologies. The In Japan, Ohisama (Sun) Zero-yen System is a programme introduced by the local government of Iida to encourage households to invest in solar PVs. The Ohisama Shinpo Energy Corporation was established as part of a system involving the non-profit organisation, Minami Shinshu Ohisama Shinpo. The company installs a solar power generator at no initial cost on the roofs of ordinary households, who pay a fixed amount (JPY 19800 or USD 244 for a 3.3-KW system) for nine years. Electricity that is generated by the solar panels but not consumed by the household can then be sold to the local power company at a fixed FIT. After the tenth year, ownership of the solar panels passes to the household at no further cost. ${ }^{37}$

\section{Disincentives to non-renewable energy}

Production of electricity from renewable energy is also encouraged indirectly through disincentives to emitting air pollutants and greenhouse gases, notably through excise taxes on fossil fuels, regulations relating to emissions from power plants, and emissions trading schemes. Generally, facilities that generate electricity from renewable energy emit no or much less air pollution and greenhouse gases than facilities that generate electricity from fossil fuels. If electricity is a good produced from either of the two substitutes - renewable or fossil energy - then providing disincentives for using one of these substitutes (fossil energy) increases demand for the other (renewable energy).

The European Union Emissions Trading Scheme (EU ETS) is at the centre of the European Union's policy to meet their emissions target set out in the Kyoto Protocol. The EU ETS was launched in 2005 and has been gradually extended since then (European Commission, 2010). ${ }^{38}$ Importantly, electricity generators should be subject to full auctioning of emission permits from 2013 onwards, taking into account their ability to pass on the increased cost of emission allowances. The EU member states, however, have an option to temporarily deviate from this rule with respect to the existing power plants, provided they meet certain conditions relating to their interconnectivity or fossil-fuel share in electricity generation and their GDP per capita relation to the EU27 average. If a Member State chooses such an option, it has to invest in improving its energy infrastructure, in clean technologies, and in diversifying its energy mix and sources of supply. These investments, to the extent possible, should be equal to the market value of the free allocation. Also, the auctioning rate has to eventually reach $100 \%$ in 2027 , rising progressively from 2013 , when it has to be at least $30 \%$ of its level in the first auctioning period. Moreover, small installations will be

37.

www.iclei.org/index.php?id=1487\&tx_ttnews\%5Btt_news\%5D=4638\&tx_ttnews\%5BbackP id\%5D=983\&cHash=f4f91145f1.

38. The EU ETS currently covers about 11000 power stations and industrial plants in 30 countries (the 27 EU member states, plus Iceland, Liechtenstein and Norway). Since its start, the scheme has encompassed power stations, combustion plants, oil refineries, iron and steel works, cement, glass, lime, bricks, ceramics, pulp, paper and board factories, above certain capacity thresholds. The scheme covers $\mathrm{CO} 2$ emissions from installations, as well as nitrous oxide emissions from certain processes. In 2012 it was extended to commercial aviation. In 2013, when the third trading period began, the EU ETS was expanded to cover additional gases and industries (petrochemicals, ammonia and aluminium). 
allowed to leave the EU ETS under certain conditions, as concerns have been raised over the cost-effectiveness of their inclusion (See Directive 2009/29/EC). ${ }^{39}$

In Australia, where the electricity sector emits the largest share of the country's $\mathrm{CO}_{2}$ emissions (over a third of the total), the energy-generating sector will be subject to a carbonpricing mechanism as of 1 July 2012. ${ }^{40}$ The price of carbon, AUD 23 per tonne $\mathrm{CO}_{2}$, will be fixed for the first three years and will then rise by $2.5 \%$ each year in real terms. The scheme will be further developed into an emissions trading scheme on 1 July 2015. The price of carbon will be freely determined by the market as of 2018. Before 2018 there will be an upper and lower limit on the allowance prices. The scheme, among other sectors, will cover electricity generators. ${ }^{41}$ However, in order to ensure a smooth transition, the government envisaged establishing the Energy Security Fund, which will allocate free carbon units and cash payments to those coal-fired electricity generators that will be strongly affected by the new policy. ${ }^{42}$ These coal-fired electricity generators will have to publish their Clean Energy Investment Plans, showing how they are planning to reduce pollution. The Government is seeking to negotiate the closing down of some coal-fired generation capacity (around 2000 MW) by 2020. Moreover, the Government promotes clean-energy projects and the deployment of renewables through investing over AUD 13 billion into clean-energy projects through the Clean Energy Finance Corporation (investment in commercialisation and deployment of renewable and clean-energy projects) and the Australian Renewable Energy Agency (investment in renewable-energy technology innovation). ${ }^{43}$

In the United States, the Acid Rain Program $\mathrm{SO}_{2}$ Allowances are at the centre of the US Environmental Protection Agency's (EPA) efforts to fight the causes of acid rain by

39. In order to be excluded, the electricity generator needs to have had reported emissions of less than 25000 tonnes of $\mathrm{CO} 2$ equivalent in each of the three years preceding the application year and have a capacity of no greater than $35 \mathrm{MW}$. Such an electricity generator may only be excluded from the EU ETS if it is covered by other measures that will contribute to an equivalent reduction in emissions.

40. The first renewable-energy certificates in Australia were introduced in 2003, on a sub-national level, by the New South Wales (NSW) state, as one of the first mandatory greenhouse-gasemissions trading schemes in the world. The NSW Greenhouse Gas Abatement Scheme requires electricity generators and large electricity consumers to purchase NSW Greenhouse Abatement Certificates. The scheme establishes annual greenhouse-gas-reduction targets in the state and requires individual electricity retailers (and certain other parties buying or purchasing electricity) in the state to meet mandatory benchmarks based on the size of their share of the electricity market. See www.greenhousegas.nsw.gov.au.

41. Other sectors include transportation, industrial processes, non-legacy waste, fugitive emissions, and landfill facilities with direct emissions of at least 25000 tonnes of $\mathrm{CO} 2$ per year. A carbon price will not apply to household transport fuels, light vehicle business transport and off-road fuel use by the agriculture, forestry and fishing industries, unless they wish to opt in. See www.cleanenergyfuture.gov.au/clean-energy-future/an-overview-of-the-clean-energylegislative-package.

42. In order to mitigate the adverse social effects of the rise in electricity prices on households, the government will introduce a household assistance package, which will include tax cuts and targeted cash transfers (increasing family benefits and other allowances).

43. See An Overview of the Clean Energy Legislative Package, Australian Government, www.cleanenergyfuture.gov.au/clean-energy-future/an-overview-of-the-clean-energylegislative-package and Clean Energy Legislative Package, Department of Climate Change and Energy Efficiency, Australian Government, www.climatechange.gov.au/en/government/submissions/clean-energy-legislative-package.aspx. 
providing disincentives to emitting $\mathrm{SO}_{2}$. The programme was introduced in 1995 and today all electricity-generating units of over $25 \mathrm{MW}$ capacity (which includes all coal-fired plants) are included in the scheme. In 2010, the EPA capped issued allowances at 8.95 million a year (one allowance $=$ permission to emit 0.9 tonnes of $\mathrm{SO}_{2}$ ), which effectively limits the $\mathrm{SO}_{2}$ emissions of the participating electricity-generating units, providing incentives for electric utilities to increase their reliance on renewable energy or to employ various energyconservation and pollution-control technologies, or both. ${ }^{44}$ No national level cap-and-trade scheme exists for greenhouse-gas emissions, but the State of California, under its Global Warming Solutions Act (AB 32), has instituted an enforceable GHG cap that will decline over time. The Act covers major sources of GHG emissions in the State, including refineries, power plants, industrial facilities, and transportation fuels. ${ }^{45}$

\section{Combinations of market-pull policy measures}

Countries usually combine different kinds of market-pull support measures in order to facilitate new investments in renewable-energy technologies (Table A.5). The use of different support measures helps countries reduce one or more barriers or challenges that impede the deployment of these technologies. Barriers typically differ across technologies according to their investment cost and application size.

Investment cost has a direct impact on the mix of measures used for different renewableenergy technologies. Hydroelectricity, biomass (depending on the feedstock) and onshore wind, for instance, are almost competitive with conventional technologies, ${ }^{46}$ such as natural gas and coal, while solar PV is relatively more expensive. In some countries, additional technology-specific market-pull incentives have been introduced in order to attract the desired investment for relatively less mature technologies. Italy implements a quota obligation policy with tradable renewable-energy certificates. However, the country introduced a specific FIT support measure to support the deployment of solar PV. In the United States, the federal production tax-credit policy is combined with state-level renewable portfolio requirements and tradable renewable certificates. In addition, some states offer additional technologyspecific tax incentives.

The application size of renewable-energy technologies also influences governments' decisions on introducing additional support measures. For small-scale renewable energy applications, many governments offer subsidy payments, cash rebates, and tax incentives in addition to a FIT (if the owners are able to sell the electricity to the grid). For large-scale applications, on the other hand, inventive policies are usually focused on investment-based tax incentives and exemptions in addition to FITs or tradable renewable-energy certificates.

44. See www.epa.gov/airmarkets/trading/factsheet.html.

45. www.arb.ca.gov/cc/capandtrade/capandtrade.htm.

46. This depends on the location and size of the application due to the fact that the cost increases with additional investments in transportation and connection. 
Table A.5. Combinations of market-pull policies in OECD countries

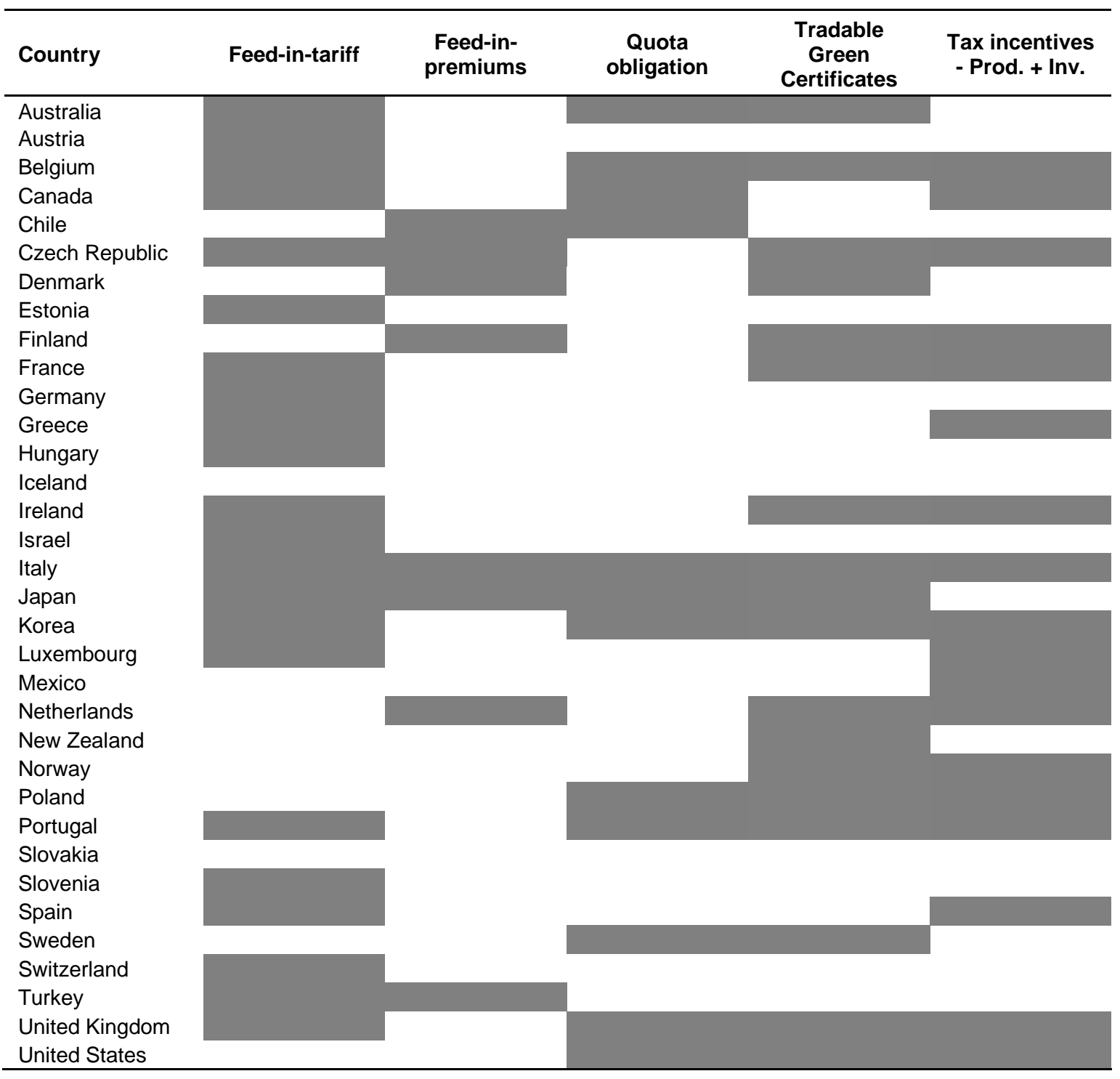

Sources: IEA Renewable Energy Database; OECD data.

\section{Import barriers}

Although the focus of this study is on domestic incentive measures, to understand the effects of such measures, they cannot be looked at in isolation. Often, incentives interact with trade barriers in ways that substantially alter the effects that the incentives would have in the absence of such barriers - for example, turning a policy that might otherwise increase imports of an electric-power technology into one that favours domestic suppliers. Among most OECD and major non-OECD economies, applied import tariffs on renewable-energybased electric equipment fall within the range of zero to $10 \%$ (Table A.6). ${ }^{47}$ Brazil and the Russian Federation are important exceptions, with applied tariffs of $14 \%$ and $15 \%$, respectively, on hydraulic turbines. Across the economies examined, import tariffs are slightly

47. These are the highest tariffs applied to other WTO member economies, as trade among partners in bilateral and regional free-trade agreements is usually duty free. 
higher for hydraulic turbines than for wind-powered generating sets, and are on average higher among non-OECD than OECD countries. Moreover, whereas the bound tariffs applied by OECD countries on these goods are close to their corresponding applied tariffs, the bound tariffs applied by many non-OECD countries are much higher than their applied tariffs. Where such large gaps exist, this means that at any time a low applied tariff could be raised to as high as the bound tariff.

Table A.6. Average import tariffs of major importers on selected renewable-energy technologies and parts, as of January $2013^{1}$

\begin{tabular}{|c|c|c|c|c|c|c|c|c|c|c|}
\hline \multirow[t]{3}{*}{ Country } & \multicolumn{4}{|c|}{ Hydraulic turbines } & \multicolumn{2}{|c|}{$\begin{array}{l}\text { Wind-powered } \\
\text { generating sets }\end{array}$} & \multicolumn{4}{|c|}{ Photovoltaic cells } \\
\hline & \multicolumn{2}{|c|}{$\begin{array}{l}\text { Of a power not } \\
\text { exceeding } \\
1000 \mathrm{~kW} \\
\text { (HS 841011) }\end{array}$} & \multicolumn{2}{|c|}{$\begin{array}{c}\text { Parts } \\
\text { (HS 841090) }\end{array}$} & \multicolumn{2}{|c|}{ (HS 850231) } & \multicolumn{2}{|c|}{$\begin{array}{l}\text { Whether or not } \\
\text { assembled in } \\
\text { modules or made- } \\
\text { up into panels } \\
\text { (HS 854140) }\end{array}$} & \multicolumn{2}{|c|}{$\begin{array}{c}\text { Parts } \\
\text { (HS 854190) }\end{array}$} \\
\hline & $\begin{array}{c}\text { MFN } \\
\text { Applied }\end{array}$ & Bound & $\begin{array}{c}\text { MFN } \\
\text { Applied }\end{array}$ & Bound & $\begin{array}{c}\text { MFN } \\
\text { Applied }\end{array}$ & Bound & $\begin{array}{c}\text { MFN } \\
\text { Applied }\end{array}$ & Bound & $\begin{array}{c}\text { MFN } \\
\text { Applied }\end{array}$ & Bound \\
\hline Australia & $5 \%$ & $15 \%$ & $5 \%$ & $15 \%$ & $0-5 \%$ & $0-10 \%$ & $0 \%$ & $0 \%$ & $0 \%$ & $0 \%$ \\
\hline Canada & $0-3.5 \%$ & $9.7 \%$ & $0-3.5 \%$ & $9.7 \%$ & $0 \%$ & $6.2 \%$ & $0 \%$ & $0 \%$ & $0 \%$ & $0 \%$ \\
\hline Chile $^{2}$ & $6 \%$ & $23-25 \%$ & $6 \%$ & $25 \%$ & $6 \%$ & $25 \%$ & $6 \%$ & $25 \%$ & $6 \%$ & $25 \%$ \\
\hline EU & $4.5 \%$ & $4.5 \%$ & $4.5 \%$ & $4.5 \%$ & $2.7 \%$ & $2.7 \%$ & $0 \%$ & $0 \%$ & $0 \%$ & $0 \%$ \\
\hline Iceland & $0 \%$ & $14-18 \%$ & $0 \%$ & $14 \%$ & $0 \%$ & $24 \%$ & $0 \%$ & $0 \%$ & $0 \%$ & $0 \%$ \\
\hline Israel & $0 \%$ & $5 \%$ & $0 \%$ & $5 \%$ & $0 \%$ & $5-12 \%$ & $0 \%$ & $0 \%$ & $0 \%$ & $0 \%$ \\
\hline Japan & $0 \%$ & $0 \%$ & $0 \%$ & $0 \%$ & $0 \%$ & $0 \%$ & $0 \%$ & $0 \%$ & $0 \%$ & $0 \%$ \\
\hline Korea & $0-8 \%$ & $0-13 \%$ & $0-8 \%$ & $0-13 \%$ & $8 \%$ & not bound & $0 \%$ & $0 \%$ & $0 \%$ & $0 \%$ \\
\hline Mexico & $0 \%$ & $35 \%$ & $0 \%$ & $35 \%$ & $0-15 \%$ & $35-40 \%$ & $0 \%$ & $35 \%$ & $0 \%$ & $35 \%$ \\
\hline New Zealand & $0 \%$ & $0 \%$ & $0 \%$ & $0 \%$ & $0-5 \%$ & $16.5 \%$ & $0 \%$ & $0 \%$ & $0 \%$ & $0 \%$ \\
\hline Norway & $0 \%$ & $6 \%$ & $0 \%$ & $6 \%$ & $0 \%$ & $3 \%$ & $0 \%$ & $0 \%$ & $0 \%$ & $0 \%$ \\
\hline Switzerland & $\begin{array}{c}\text { CHF } \\
12 / 100 \\
\text { gross kg }\end{array}$ & $\begin{array}{c}\text { CHF } \\
12 / 100 \\
\text { gross kg }\end{array}$ & $\begin{array}{c}\text { CHF 7- } \\
16 / 100 \\
\text { gross kg }\end{array}$ & $\begin{array}{c}\text { CHF 7- } \\
16 / 100 \\
\text { gross kg }\end{array}$ & $\begin{array}{c}\text { CHF } \\
11 / 100 \\
\text { gross kg }\end{array}$ & $\begin{array}{c}\text { CHF } \\
11 / 100 \\
\text { gross kg }\end{array}$ & $0 \%$ & $0 \%$ & $0 \%$ & $0 \%$ \\
\hline Turkey & $4.5 \%$ & $\begin{array}{c}\text { not } \\
\text { bound }\end{array}$ & $4.5 \%$ & $\begin{array}{c}\text { not } \\
\text { bound }\end{array}$ & $0-2.7 \%$ & $10.8-14 \%$ & $0 \%$ & $0 \%$ & $0 \%$ & $0 \%$ \\
\hline United States & $3.8 \%$ & $3.8 \%$ & $3.8 \%$ & $3.8 \%$ & $2.5 \%$ & $2.5 \%$ & $0 \%$ & $0 \%$ & $0 \%$ & $0 \%$ \\
\hline Argentina & $14 \%$ & $35 \%$ & $14 \%$ & $35 \%$ & $0 \%$ & $35 \%$ & $0-12 \%$ & $35 \%$ & $0 \%$ & $35 \%$ \\
\hline Brazil & $14 \%$ & $35 \%$ & $14 \%$ & $25-35 \%$ & $0 \%$ & $35 \%$ & $0-12 \%$ & $0-35 \%$ & $0 \%$ & $25 \%$ \\
\hline China & $10 \%$ & $10 \%$ & $6 \%$ & $6 \%$ & $8 \%$ & $8 \%$ & $0 \%$ & $0 \%$ & $0 \%$ & $0 \%$ \\
\hline Egypt & $5 \%$ & $20 \%$ & $2 \%$ & $20 \%$ & $5 \%$ & $10 \%$ & $0 \%$ & $0 \%$ & $0 \%$ & $0 \%$ \\
\hline India & $7.5 \%$ & $25 \%$ & $7.5 \%$ & $25.0 \%$ & $7.5 \%$ & $25 \%$ & $0 \%$ & $0 \%$ & $0 \%$ & $0 \%$ \\
\hline Indonesia & $5 \%$ & $30 \%$ & $5 \%$ & $30 \%$ & $10 \%$ & $40 \%$ & $0 \%$ & $0 \%$ & $0 \%$ & $0 \%$ \\
\hline Malaysia & $0 \%$ & $5 \%$ & $0 \%$ & $\begin{array}{c}\text { not } \\
\text { bound }\end{array}$ & $0 \%$ & $30 \%$ & $0 \%$ & $0 \%$ & $0 \%$ & $0 \%$ \\
\hline Russia & $15 \%$ & $15 \%$ & $15 \%$ & $15 \%$ & $0 \%$ & $5 \%$ & $0-10 \%$ & $0 \%$ & $10 \%$ & $0 \%$ \\
\hline South Africa & $0 \%$ & $0 \%$ & $0 \%$ & $0 \%$ & $0 \%$ & $20 \%$ & $0 \%$ & $10 \%$ & $0 \%$ & $10 \%$ \\
\hline
\end{tabular}

1. Note, for many countries, the MFN tariffs applied to least developed countries are lower or zero. In addition, tariffs applied on goods imported from partners in bilateral or regional free-trade agreements are also frequently zero.

2. Chile applies different tariff rates in the Arica and Magallanes regions in order to help isolated communities.

Data sources: MFN Applied tariffs: Market Access Database (http://madb.europa.eu/mkaccdb2/indexPubli.htm); Bound tariffs: WTO. 


\section{Technology-push policies}

The following sections discuss incentives used by governments to push renewable-energy technologies onto the market. These incentive measures include various financial and tax incentives, government encouragement of private funding and export credits.

\section{Government support for research, development and demonstration $(R D \& D)$}

The innovation system of a country comprises both public and private elements. Governments play a very important role in research, innovation and demonstration, mainly through supporting the public research system, which comprises universities and public research institutions (PRIs). These research efforts are usually complemented by innovation efforts undertaken by private research institutions and corporations, which may benefit from government support in the form of various tax incentives and a legal framework that enables them to reap the benefits of their discoveries by formalising rights to intellectual property. Countries differ when it comes to the structure and role of institutions governing the invention, development and adoption of new technologies. Some rely on public research institutions, while in others RD\&D is mostly carried out by private institutions and corporations. The type of research undertaken by research institutions also differs across countries. Some institutions pursue basic research, which usually implies taking high risks and longer project time horizons, while others focus on short-term market-oriented research, including development work, problem-solving and technical assistance (OECD, 2010).

There are significant differences in the ways that Europe and the United States fund industrial R\&D. While the United States has an integrated, but decentralised, innovation system, characterised by large federally funded projects mostly focussing on basic research and benefitting mostly private firms, the European innovation systems are more fragmented and comprise many small-scale projects. These vast differences stem in part from their respective intellectual property laws. In many European countries - e.g. Germany, Italy and Sweden - researchers can benefit from ownership rights for their discoveries, which encourages small, private projects (Nelson et al., 2006). Moreover, EU Member States are not allowed to finance competitive $R \& D$, while there is no such restriction in the United States or Japan, where public funds are available to industries for pre-competitive and competitive $\mathrm{R} \& \mathrm{D}(\mathrm{EC}, 2005){ }^{48}$

The European Union has made efforts to change this situation by establishing the European Institute of Innovation and Technology (EIT), which received a EUR 308.9 million grant for the years 2009-13 to address the "innovation gap" through connecting academia, research institutions and businesses to help innovations come to the market. The major focus of the EIT is to establish knowledge and innovation communities, focussing on key strategic priorities, two of which are climate-change adaptation and mitigation, and sustainable energy (EIT, 2011). Also, the European Renewable Energy Research Centres Agency (EUREC), founded in 1991, plays a role as a platform for collaboration on renewable-energy RD\&D in the EU. EUREC currently comprises 50 members, including mainly public research centres and university laboratories (EUREC, 2011).

In the European Union, every Member State has its own national network of government research agencies and other institutions. For instance, in Denmark, energy research is primarily managed by the Danish Energy Agency, which is involved in numerous

48. Pre-competitive R\&D is distanced from the market as it is focused on "generic" or "enabling" technologies rather than the development of final-use products targeted on specific markets, which is the aim of competitive R\&D (see Quintas and Guy, 1995). 
programmes focussing on renewable-energy RD\&D. ${ }^{49}$ Danish companies undertaking research and development both at the innovation and manufacturing stages can benefit from government help. Small innovative firms can benefit from seed and start-up funding provided by the Danish Investment Fund, which is government-sponsored (DIF, 2011). The government also helps Danish manufacturers co-operate with foreign RD\&D centres. For example, the Innovation Centre Denmark was established in Munich to encourage cooperation with German research centres (ICD - Munich, 2011). In Germany, the Helmholtz Association of National Research Centres is responsible for basic technology research. Three out of its 16 institutes focus on energy technology (Helmholtz Association, 2011). The federal government also encourages private-sector renewable-energy research through a combination of facilitating start-up companies, public procurement of new technologies and issuing standards to drive innovation. The Fraunhofer-Gesellschaft supports applied research by awarding federal-funded contracts to both domestic and foreign institutions, mainly focussing on manufacturing (Fraunhofer, 2011). ${ }^{50}$

In the United States, the federal government provides support at all stages of pushing technology into the market. The Department of Energy (DOE) administers both innovation research grants and more conventional research grants for energy projects. The biggest federal programme with a focus on the initial stages of renewable-energy research is the DOE's Advanced Research Projects Agency for Energy (ARPA-E). In February 2009, ARPA-E was endowed with USD 400 million. ARPA-E focuses exclusively on high-risk, high-payoff technology developments germane to energy generation, storage and utilisation. ARPA-E thus supports only applied research, usually at its initial stage. Due to the nature of ARPA-E's investment, only a fraction of the projects funded by it is successful in reaching the marketplace. The DOE also runs more specific research projects in the renewable-energy sector, which mostly focus on supporting research at the production stages (ARPA-E, 2013). ${ }^{51}$

In China, many energy technologies are still sourced from developed countries. Apart from government support for diversification and improvement of the quality of technology imports in the renewable-energy sector (mainly through the International Science and Technology Co-operation Program on New and Renewable Energy), where the focus is mainly on supporting domestic manufacturers and their foreign partners, China also encourages domestic RD\&D to diminish its dependence on foreign technologies. This is the main objective of the State High-Tech Development Programme (863 Programme). China has also designed a system of incentives that encourage research collaboration between industry and academia. The policies include: financial incentives (e.g. loans to R\&D-focussed enterprises), tax incentives (e.g. deductions of $R \& D$ expenses from taxable income) and state financing of high-tech development centres (Ministry of Science, 2012).

While many countries strive to invest in technology-related R\&D, those with limited technological-development capacity typically try to overcome this problem by establishing

49. These programmes include the Energy Technology Development and Demonstration Programme, ForskEL (funds renewable-energy generating technologies and a reliable transmission system), ForskVE (focuses on smaller electricity-generating technologies) and ELforsk (supports RD\&D programmes in more efficient electricity use). Both ForskEL and ForskVE are funded by the Danish Transmission System operator (Energinet).

50. Among the biggest private companies investing in renewable-energy RD\&D are Siemens, major utilities (RWE, Eon, Vattenfall), and car manufacturers (BMW, Volkswagen and Daimler).

51. For example, it embarked on the SunShot initiative, which is a programme focussing on lowering costs of renewable-energy deployment through pursuing innovation in four areas: solar-cell technology, improvements in manufacturing processes and power electronics used in installations, and installation and system design (DOE, 2013b). 
partnerships, mostly in the form of joint ventures, with more advanced manufacturers from overseas. Such international joint ventures can be based on a mutually beneficial exchange: the foreign company offers a technology transfer at a lower cost than it would have if it did not have a stake in the joint venture's future earnings. In exchange, it receives a preferential treatment on the domestic market of its partner, to which it would not have access otherwise. Sometimes, however, the state is heavily involved in sealing such deals given its interest in encouraging technology transfers from abroad. For example, the US Natcore Technology, the Zhuzhou Hi-Tech Industrial Development Zone and Chuangke Silicon Ltd. (a producer of polycrystalline silicon) set up a joint venture, Natcore China, in June 2010. Under this agreement, Natcore China is $55 \%$ owned by Natcore Technology. The joint venture was funded by an initial USD 3 million investment, of which USD 0.5 million was Natcore Technology's contribution, while the Chinese partnership contributed the remaining USD 2.5 million. ${ }^{52}$ Since the Zhuzhou Hi-Tech Industrial Development Zone is government-supported, the joint venture can expect to receive some further tax and financial incentives from the Chinese government (Natcore, 2010a; 2010b).

\section{Government support for product development and manufacturing}

In addition to their financial support for research, development and demonstration, many governments provide incentives to their renewable-energy industries for product development and manufacturing through financial and tax incentives. These include grants for research and development at the production stages, detailed product design, manufacturing, technology operation and promotion, and investment incentives for equipment manufacturers, mainly in the form of tax breaks.

Grants for research and development of renewable-energy equipment are sometimes provided through the same programme that provides funding at the RD\&D stages of pushing a given technology onto the market, but more often by other programmes that focus exclusively on product development and improvement of manufacturing. Usually, these programmes are administrated by national-energy, innovation or development agencies. The European Union, for instance, provides capital, project and contingent grants to small and medium size enterprises (SMEs) for technologies that have reached the end of demonstration phase or the early stage of commercialisation. In Japan, the New Energy and Industrial Technology Development Organization (NEDO) supports not only the innovation phase of a project, but also later stages of product development and manufacturing. NEDO finances not only feasibility studies for technologies in their development phase, but also basic and detailed product design, manufacturing, installation, technology operation and promotion, both in the country and abroad, especially in Asia. NEDO's budget for the financial year 2011 was about USD 1.9 billion (NEDO, 2012a). In the period between January and May 2012 alone, NEDO co-operated in the introduction of its renewable-energy and energyconservation technologies with India, Myanmar, the Kyrgyz Republic, Portugal, Spain, and Thailand (NEDO, 2012b).

Governments also provide support for manufacturing through a combination of preferential loans, loan guarantees and tax credits. For example, in the United States, both direct loans and loan guarantees granted to the energy sector are authorised under the Title 17 of the Energy Policy Act of 2005 and administered by the DOE (CFDA, 2013). By the end of

52. At the heart of the joint venture is Natcore Technology's patented Liquid Phase Deposition (LPD) technology, licensed from Rice University where it was developed. Using LPD makes solar cells potentially cheaper and cleaner to produce. As part of the joint-venture agreement, Natcore Technology licenses the LPD technology for sale in China only. The joint venture will have a life span of at least 20 years and it has been granted tax exemptions for at least three years. 
FY 2011, the US government had committed to guarantee USD 16 billion in loans for the purpose of investment in renewable-energy projects in three categories: manufacturing projects, stand-alone projects, and large-scale integration projects that may combine multiple eligible renewable energy, energy efficiency and transmission technologies in accordance with a staged development scheme (lpo.energy.gov). For example, Solyndra and Solo Power (two US solar PV manufacturers) obtained loan guarantees of USD 535 million and USD 197 million in 2009 and 2011 respectively in order expand their operations and build new factories in the United States (SoloPower, 2011; Solyndra, 2011). ${ }^{53}$ At the end of October 2011, a bill was introduced into the US Senate (the Make it in America Tax Credit Act, S. 176) that provided an additional USD 5 billion for the Advanced Manufacturers Tax Credit Program.

The European Commission provides the legal and financial framework for public funding in all EU Member States. Several countries in Europe offer grants, reduced-interest loans and loan guarantees for manufacturing plants specific to renewable energy. Usually, the same eligibility conditions apply for domestic and foreign investors. In France, for instance, FOGIME (Fonds de Garantie des Investissements de Maitrise de l'Energie) is a mutual guarantee fund set up by BDPME-SOFARIS (the SME Development Bank and its credit insurance subsidiary) and ADEME (Agence de l'Environnement et de la Maîtrise de $l^{\prime}$ Energie) ${ }^{54}$ Its mission is to encourage SME investment in energy-management programmes by guaranteeing the loans that they contract from banks. FOGIME provides SMEs with an extended loan guarantee: $70 \%$ as against $40 \%$ available within the framework of the French National SME Development Guarantee Fund, the balance of 30\% being financed by ADEME.

Direct loans and loan guarantees are also very popular tools for encouraging technology development and deployment in emerging economies. For example, in 2010 alone, the China Development Bank provided over USD 30 billion in subsidised loans for investment to its domestic solar manufacturers. ${ }^{55,56}$ Moreover, China offers tax holidays for companies that qualify as "new technology enterprises" operating in special economic-development zones. It also subsidises their production costs through lending land at very low rates and selling them rare-earth metals, which are crucial for the production of wind turbines and some batteries, at prices kept low through export restrictions on these metals.

The Chinese Special Fund for Wind Power Equipment formerly provided grants to only those wind-turbine manufacturers who purchased key parts and components domestically. In 2011, however, China revoked its Special Fund for Wind Power equipment manufacturing

53. In September 2011, Solyndra, Evergreen Solar and Spectra Watt filed for Chapter 11 bankruptcy and closed its operations. Another company, Beacon Power (the Massachusetts-based flywheel storage company) filed for Chapter 11 bankruptcy on 30 October 2011. The company received a USD 43 million loan guarantee under the DOE's loan-guarantee programme. The loan supported the construction of a $20 \mathrm{MW}$ flywheel energy storage plant in Stepentown in the State of New York.

54. See ADEME (2011).

55. See Lacey (2011).

56. According to the Mercom Capital Group, the China Development Bank granted the following loans to its domestic solar manufacturing companies: JA Solar - USD 4.4 billion loan, LDK Solar - USD 8.9 billion, Suntech Power Holdings — USD 7.3 billion, Trina Solar — USD 4.4 billion, Yingli Green Energy - USD 5.3 billion. See Loans and Credit Agreements involving Chinese Banks to Chinese Solar Companies since Jan 2010, Mercom Capital Group, 25 September 2011, http://mercomcapital.com/news.php. 
subsidies. ${ }^{57}$ Chinese state-controlled banks provide significant credit lines to both local wind turbine and solar panel manufacturers. In January 2012, China's second-largest wind-turbine manufacturer, Goldwind, signed a financial agreement with the China Development Bank for wind power projects worth USD 5.5 billion. ${ }^{58}$ Malaysia offers $100 \%$ tax holidays for solar manufacturers for up to 15 years (NEI, 2011).

In Germany, grants, reduced interest loans and public guarantees are offered at federal and state levels for all manufacturing plants. There are two major programmes to direct the allocation of cash incentives: the Joint Task Programme and, in Eastern Germany, the Investment Allowance Programme. These programmes reimburse part of the direct investment costs during the investment phase of a project. According to BSW-Solar (2010), EUR 2.2 billion were invested by the German PV industry into the construction, expansion and modernisation of manufacturing factories in 2008 (Grau et al., 2011).

Numerous sub-national jurisdictions also support manufacturing through investment incentives - corporate income-tax credits or rebates, low-cost loans, property-tax abatements, reimbursement for training, or combinations of these measures. Many states in the United States provide such investment incentives, typically through general economic development programmes. Some of these programmes are targeted at high-technology firms, and some are even more specifically targeted at energy (e.g. the State of Oregon's Business Energy Tax Credit) or even specific renewable-energy technologies (e.g. the State of Washington's Solar Energy Systems Manufacturers Preferential Tax Rate). Arizona, California, Connecticut, Florida, Kansas, Montana, New Mexico, North Carolina, Ohio, Oregon, Texas, Virginia and Washington provide some sort of manufacturing tax incentive or grant for all renewable energy technologies, while Arkansas, Michigan, New Jersey, Oklahoma and Washington offer incentives for wind or solar PV, or both. Under Oklahoma's Alternative Energy Sources Tax Credit, manufacturers of small wind turbines may earn a tax credit of USD 25 per square foot (USD 269 per square metre) of rotor-swept area (WTO, 2011). ${ }^{59}$ Good Jobs First's "Subsidy Tracker" (www.goodjobsfirst.org/subsidy-tracker) lists at least one hundred investment incentives, worth anywhere from a few hundred US dollars to as much as USD 24.4 million apiece, provided to renewable-energy manufacturers by US States in recent years.

In January 2010 the Government of Canada's Province of Ontario signed a Green Energy Investment Agreement (GEIA) with a Korean consortium headed by the Samsung C\&T Corporation, in which the latter initially committed to invest a total of CAD 7 billion over six years in renewable energy development and manufacturing in the province. The consortium thus became eligible for economic development assistance worth up to CAD 110 million over the lifetime of the contracts (generally, 20 years). This assistance will only be paid if all conditions under the contract are met. One condition is that all factories and renewable-energy projects have to be operational by 2014 (Quilter, 2011).

In China, even relatively small companies are intertwined with local governments through complex credit relationships. This has meant that when they have gotten into financial trouble, local governments have often come to their rescue. In September 2012, for example, Suntech Power Holdings Co. (STP), the world's largest solar-panel maker, received a USD 32 million loan organised in part by Wuxi, the city in which it is based. The following month, LDK

57. See China to End Challenged Subsidies in Wind Power Case, International Center for Trade and Sustainable Development, 13 June 2011, http://ictsd.org/i/news/biores/108435/.

58. Goldwind signed another credit line agreement, worth RMB 10 billion with the Industrial and Commercial Bank of China in November 2011.

59. The area of the two-dimensional circle swept by the blades. 
Solar, the world's second largest producer of solar wafers, sold a $19.9 \%$ stake to Heng Rui Xin Energy, a Chinese state-run entity ${ }^{60}$, for approximately USD 23 million. This reluctance by local and provincial governments to allow their local solar manufacturing plants to shut down is widely acknowledged as one of the main impediments to the transition to structural adjustment in the industry (Bradsher, 2012; Haley and Haley, 2013).

\section{Government promotion of renewable-energy-technology exports}

Many governments support their national exporters of renewable-energy technologies through export credits. Official export credits are provided through Export Credit Agencies (ECAs), which provide credits to foreign buyers either directly or via private financial institutions benefiting from their insurance or guarantee cover. ECAs are either government institutions or private companies operating on behalf of the government. The OECD regulates export credit arrangements by providing a framework for the use of officially supported export credits (known as the "Arrangement"), which came into effect in 1978. The Arrangement establishes common boundaries on the generosity of financial terms and conditions for officially supported export credits ${ }^{61}$ for its participants. ${ }^{62}$ Export credits for the renewable-energy sector are set out in special rules called "sector understandings". Currently, the Arrangement comprises four such "sector understandings", one of which is "Renewable Energies and Water Projects". This particular sector understanding can be found in Annex 4 of the Arrangement on Officially Supported Export Credits (OECD, 2011). Annex 4 creates special repayment terms for the renewable-energy sector: while other export credits need to be repaid within either five or ten years, ${ }^{63}$ credits related to the export of renewable-energy equipment are allowed to establish a repayment term of up to 18 years. Through September 2011, more than 38 export credits had been granted under the Annex 4 arrangements.

Most of these export credits included longer repayment terms than stipulated by the general Arrangement regulations for other sectors. For example, in April 2009, Export-Import Bank (Eximbank) of Korea and the United States Export-Import Bank signed a co-operation agreement that opened a USD 500 million credit line from the United States to Korea for purchasing renewable-energy related equipment manufactured in the United States. The Korea Eximbank obtained the credit line for 15 years at the lowest interest rate allowed by the OECD Export Credit Guidelines. ${ }^{64}$

60. The state-owned Asset Management Co. holds a 40\% stake, and Hi-Tech Wealth Investment and Developing Co. holds the remaining 60\% (He, 2012).

61. Official support may be provided in the form of (a) an export credit guarantee or insurance (pure cover); (b) direct credit, direct financing or refinancing or interest-rate support; or (c) any combination of (a) and (b).

62. Current participants in the Arrangement (as of May 2013) are: Australia, Canada, the European Union, Japan, Korea, New Zealand, Norway, Switzerland and the United States.

63. The maximum repayment term varies according to the classification of the country destination. For Category 1 countries (high-income OECD countries, defined by the World Bank on an annual basis according to GNI per capita), the maximum repayment term is usually five years. For Category II countries (all the other countries), the maximum repayment term is ten years.

64. The US Eximbank offers long-term financing arrangements, in the form of loan guarantees or direct loans, which support repayment terms of up to 15 years for renewable-energy projects pursued by Korean companies. In addition, a 15-year repayment term on the loan value can often be rescheduled to begin six months after the completion of the project. The US Eximbank can also support the capitalisation of interest during construction and finance local costs equal to $30 \%$ of the US contract price. See United States and Korea: Joint financing initiative for trade and investment in "green" products, Global Trade Alert, 31 October 2011, 
In the period 2005-09, OECD countries reported USD 2.7 billion in tied and untied aid for renewable energy (NEI, 2011). Exporters of RE technologies in many European and Asian countries enjoy the support of a dedicated government agency overseeing all government resources promoting their exports. The German Renewable Energies Export Initiative, for example aims at helping the domestic renewable-energy industry engage more with foreign markets through increasing their export activities (DEA, 2011).

In addition to export credits, some governments provide financial and diplomatic support to domestic companies when they bid for important projects abroad. Several Japanese solar PV companies agreed to set up consortiums of three to nine companies each to bid for projects in five different geographic regions (Indonesia, the Middle East and North Africa, Latin America, Mongolia and Thailand). The Japanese government is considering whether to provide financial assistance to these consortiums so that they may more effectively compete with Chinese solar companies. ${ }^{65}$

\section{Liquid biofuels}

\section{Market-pull policies}

\section{Tax preferences relating to final consumption}

Most OECD countries have initially supported the use of ethanol and biodiesel - and therefore production, where border protection is high - through tax preferences tied to fuelexcise taxes or sales taxes normally charged on transport fuels. (These tax preferences do not benefit aviation biofuels used in international flights, as no excise tax is charged on such fuel.) The federal governments of Canada and the United States formerly granted excise-tax reductions for biofuels, but during the previous decade the US federal government converted its tax exemption into a tax credit, and Canada created a new system based on productionlinked payments. Nonetheless, three Canadian provinces and thirteen US states offer some reductions in excise taxes or sales taxes for biofuels, sometimes on pure biofuels but in many cases for specific blends, such as E85 (Table A.7). Other countries applying reduced end-user taxes on biofuels include Brazil and Switzerland.

Australia favours biofuels through rebates on its AUD 0.318 per litre fuel duty. These rebates are scheduled to be phased out after June 2020. By the end of the phase-out period, "normal" excise taxes will be applied to the fuels. These excise taxes will be lower than those for petroleum fuels, in line with the federal government's decision to move towards tax rates that are roughly proportional to the energy density of each fuel.

www.globaltradealert.org/measure/united-states-and-korea-joint-financing-initiative-tradeand-investment-green-products.

65. See "Japan to support Five Domestic Consortia with Subsidies/Diplomacy to fight Chinese Solar Energy Competition in Asia and Africa", Green World Investor, 4 July 2011, www.greenworldinvestor.com/2011/07/04/japan-to-support-five-domestic-consortia-withsubsidiesdiplomacy-to-fight-chinese-solar-energy-competition-in-asia-and-africa/. 
Table A.7. Tax preferences on retail sales of ethanol and biodiesel in OECD and non-OECD EU countries

(Currency per litre, or percentage of full excise tax on gasoline or diesel)

\begin{tabular}{|c|c|c|c|c|}
\hline \multirow[b]{2}{*}{ Country } & \multicolumn{2}{|r|}{ Ethanol } & \multicolumn{2}{|r|}{ Biodiesel } \\
\hline & Local currency & Comment & Local currency & Comment \\
\hline Argentina & $39 \%$ & $\begin{array}{l}\text { Combination of the } 20 \% \\
\text { hydrocarbon tax and the gasoline or } \\
\text { diesel tax. }\end{array}$ & $40 \%$ & $\begin{array}{l}\text { Combination of the } 20 \% \text { hydrocarbon } \\
\text { tax and the gasoline or diesel tax. }\end{array}$ \\
\hline $\begin{array}{l}\text { Australia } \\
\text { (federal) }\end{array}$ & AUD 0.38143 & $\begin{array}{l}\text { Ethanol Production Grant for } \\
\text { domestically produced fuel only } \\
\text { (exactly offsets fuel excise duty); } \\
\text { extended until at least } 30 \text { June } \\
2021 .\end{array}$ & AUD 0.38143 & $\begin{array}{l}\text { Cleaner Fuel Grant Scheme payment } \\
\text { (exactly offsets fuel excise duty or } \\
\text { excise equivalent customs duty); } \\
\text { extended until at least } 30 \text { June } 2021 .\end{array}$ \\
\hline $\begin{array}{l}\text { Canada } \\
\text { (federal) }\end{array}$ & - & $\begin{array}{l}\text { Federal fuel-tax exemptions } \\
\text { repealed in } 2008 .\end{array}$ & - & $\begin{array}{l}\text { Federal fuel-tax exemptions repealed } \\
\text { in } 2008 \text {. }\end{array}$ \\
\hline Ontario & - & - & CAD 0.143 & Fuel-tax exemption. \\
\hline Quebec & - & - & CAD 0.143 & $\begin{array}{l}\text { Refund on the fuel tax on the } \\
\text { purchase of pure (B100) biodiesel. }\end{array}$ \\
\hline Nova Scotia & - & - & CAD 0.154 & $\begin{array}{l}\text { Fuel-tax exemption. Only biodiesel } \\
\text { produced in NS is eligible. }\end{array}$ \\
\hline
\end{tabular}

\section{EU member states}

\begin{tabular}{|c|c|c|c|c|}
\hline Austria & EUR 0.033 & $\begin{array}{l}100 \% \text { duty exemption of EUR } \\
0.554 / \text { litre on ethanol share of E85. } \\
\text { Otherwise reduction shown is on } \\
\text { entire blend if contains more than } \\
4.4 \% \text { ethanol }\end{array}$ & EUR 0.028 & $\begin{array}{l}100 \% \text { duty exemption of EUR } \\
0.425 / \text { litre on B100. Otherwise } \\
\text { reduction shown is on entire blend if } \\
\text { contains more than } 4.4 \% \text { biodiesel }\end{array}$ \\
\hline Belgium & EUR 0.055 & $\begin{array}{l}\text { Only for fuel containing } 7 \% \\
\text { ethanol or approx. } 15 \% \text { ETBE }\end{array}$ & EUR 0.16 & $\begin{array}{l}\text { Only if used in blends of at least } 5 \% \text {, } \\
\text { and when purchased from a } \\
\text { government designated Belgian bio- } \\
\text { diesel producer }\end{array}$ \\
\hline $\begin{array}{l}\text { Czech } \\
\text { Republic }\end{array}$ & - & - & $\begin{array}{l}\text { CZK } 3.29 \text { to } \\
\text { CZK } 10.95 \\
\text { (EUR to EUR) }\end{array}$ & $\begin{array}{l}\text { For blends containing at least } 30 \% \\
\text { biodiesel, excise-tax is reduced } \\
\text { proportionally to the share of } \\
\text { biodiesel in the blended fuel. }\end{array}$ \\
\hline Finland & - & - & - & - \\
\hline France & EUR 0.14 & Valid through 2013. & EUR 0.08 & Valid through 2013. \\
\hline Germany & EUR 0.6698 & $\begin{array}{l}\text { Only for ethanol exceeding quota } \\
\text { and for E85 }\end{array}$ & EUR 0.0214 & - \\
\hline Latvia & EUR 0.29 & $\begin{array}{l}70 \% \text { reduction in excise only for fuel } \\
\text { with ethanol content of } 70-85 \%\end{array}$ & $\begin{array}{l}\text { LVL } 0.07 \text { or } \\
\text { LVL } 0.234 \\
\text { (EUR } 0.10 \text { or } \\
\text { EUR } 0.33 \text { ) }\end{array}$ & $\begin{array}{l}\text { No tax incentive on blends containing } \\
\text { less than } 30 \% \text { biodiesel; for blends } \\
\text { containing } 30-99 \% \text { biodiesel, tax } \\
\text { incentive is approx. } 30 \% \text { of original } \\
\text { excise; for B100, tax exemption is } \\
100 \%\end{array}$ \\
\hline Lithuania & $\begin{array}{l}\text { up to LTL } 2.00 \\
\text { (EUR } 0.3236 \text { ) }\end{array}$ & $\begin{array}{l}\text { For blends containing less than } 30 \% \\
\text { ethanol, excise duty is reduced } \\
\text { proportional to additional share of } \\
\text { ethanol above the minimum } \% \text { that } \\
\text { is mandatory; for blends containing } \\
30 \% \text { or more ethanol in blend, } \\
\text { reduction is proportional to actual } \\
\text { share of ethanol in blend }\end{array}$ & $\begin{array}{l}\text { up to LTL } 1.14 \\
\text { (EUR } 0.2746)\end{array}$ & $\begin{array}{l}\text { For blends containing less than } 30 \% \\
\text { biodiesel, excise duty is reduced } \\
\text { proportional to additional share of } \\
\text { biodiesel above the minimum \% that } \\
\text { is mandatory; for blends containing } \\
30 \% \text { or more biodiesel in blend, } \\
\text { reduction is proportional to actual } \\
\text { share of biodiesel in blend. }\end{array}$ \\
\hline Slovakia & EUR 0.4650 & $\begin{array}{l}\text { Excise tax exemption is } 100 \% \text { on } \\
\text { ethanol used in blends of up to } \\
7.05 \% \text { ETBE by volume }\end{array}$ & EUR 0.4350 & $\begin{array}{l}\text { Excise tax exemption is } 100 \% \text { on } \\
\text { biodiesel used in blends of up to } 5 \% \\
\text { biodiesel by volume }\end{array}$ \\
\hline
\end{tabular}


Table A.7. Tax preferences on retail sales of ethanol and biodiesel in OECD and non-OECD EU countries

\begin{tabular}{|c|c|c|c|c|}
\hline \multirow{2}{*}{ Country } & \multicolumn{2}{|r|}{ Ethanol } & \multicolumn{2}{|r|}{ Biodiesel } \\
\hline & Local currency & Comment & Local currency & Comment \\
\hline Spain & - & $\begin{array}{l}100 \% \text { excise duty exemption expired } \\
\text { at end of } 2012\end{array}$ & - & $\begin{array}{l}100 \% \text { excise duty exemption expired } \\
\text { at end of } 2012\end{array}$ \\
\hline $\begin{array}{l}\text { United } \\
\text { Kingdom }\end{array}$ & - & - & - & $\begin{array}{l}\text { GBP 20p/litre duty derogation for } \\
\text { biodiesel made from used cooking oil } \\
\text { expired on } 31.03 .2012\end{array}$ \\
\hline Japan & $\begin{array}{l}\text { JPY } 53.8 \\
\text { (USD } 0.58)\end{array}$ & $\begin{array}{l}\text { Excise-tax exemption per gallon of } \\
\text { pure ethanol blended with gasoline, } \\
\text { up to E10. Recently extended to } 31 \\
\text { March } 2018 \text {. }\end{array}$ & - & - \\
\hline Mexico & .. & .. & .. & .. \\
\hline New Zealand & NZD 0.505 & $\begin{array}{l}\text { Represents exemption from gasoline } \\
\text { excise tax }\end{array}$ & - & - \\
\hline Switzerland & $\begin{array}{c}\text { USD } 0.77 \\
(\mathrm{CHF} 0.7312)\end{array}$ & $\begin{array}{l}\text { Excise tax exemption. Fuel must } \\
\text { comply with certain life-cycle } \\
\text { sustainability requirements. }\end{array}$ & $\begin{array}{c}\text { USD } 0.80 \\
\text { (CHF } 0.7587)\end{array}$ & $\begin{array}{l}\text { Excise tax exemption. Fuel must } \\
\text { comply with certain life-cycle sustain- } \\
\text { ability requirements. }\end{array}$ \\
\hline \multicolumn{5}{|l|}{ United States } \\
\hline Federal $^{1}$ & - & - & $\begin{array}{l}\text { USD } 0.264 \\
\text { (USD 1.00/gal) }\end{array}$ & $\begin{array}{l}\text { Biodiesel Mixture Excise Tax Credit; } \\
\text { due to expire end-2013. }\end{array}$ \\
\hline Alaska & $\begin{array}{l}\text { USD } 0.016 \\
\text { (USD } 0.06 / \mathrm{gal})\end{array}$ & In certain geographic areas & - & - \\
\hline Hawaii & $\begin{array}{c}\text { USD } 0.0377 \\
\text { (USD } 0.14285 / \mathrm{gal})\end{array}$ & $\begin{array}{l}\text { Alternative Fuel Tax Rate: } \\
\text { USD }\left(0.0025+\left(0.145^{\star} \text { diesel tax }\right)\right) \\
\text { per gallon of pure ethanol. }\end{array}$ & $\begin{array}{l}\text { USD } 0.033 \\
\text { (USD } 0.125 / \text { gal) }\end{array}$ & $\begin{array}{l}\text { Alternative Fuel Tax Rate: } \\
\text { USD }\left(0.0025+\left(0.25^{*} \text { diesel tax }\right)\right) \text { per } \\
\text { gallon of pure biodiesel. }\end{array}$ \\
\hline Illinois & $\begin{array}{l}20 \% \text { reduction in } \\
\text { sales tax for } E 10 \text {; } \\
\text { full sales-tax } \\
\text { exemption for } E 70\end{array}$ & $\begin{array}{l}\text { Tax preferences apply through end- } \\
2018 .\end{array}$ & $\begin{array}{l}\text { Full exemption of } \\
6.25 \% \text { sales tax } \\
\text { for } \mathrm{B} 11 \text { and } \\
\text { higher blends }\end{array}$ & $\begin{array}{l}\text { Tax preferences apply through end- } \\
2018 .\end{array}$ \\
\hline lowa & $\begin{array}{l}\text { [1] Up to } 0.021 \\
\text { (USD } 0.08 / \mathrm{gal}) \\
\text { [2] USD } 0.042 \\
\text { (USD 0.16/gal) }\end{array}$ & $\begin{array}{l}\text { [1] Ethanol Promotion Tax Credit: } \\
\text { payment rate depends on biofuel } \\
\text { blend rate and sales volume; expires } \\
\text { end- } 2020 \text {. } \\
\text { [2] E85 Gasoline Promotion Tax } \\
\text { Credit: Credit is per unit of blended } \\
\text { fuel for retail stations dispensing } \\
\text { E85 for use in motor vehicles; } \\
\text { expires end-2017. }\end{array}$ & $\begin{array}{c}\text { USD } 0.012 \\
\text { (USD } 0.045 / \text { gal) }\end{array}$ & $\begin{array}{l}\text { Biodiesel Blended Fuel Tax Credit: } \\
\text { Tax credit per unit of blended fuel for } \\
\text { retail stations dispensing B5 or } \\
\text { above blends for use in motor } \\
\text { vehicles; expires end-2017. }\end{array}$ \\
\hline Kansas & $\begin{array}{l}\text { up to USD } 0.017 \\
\text { (USD 0.065/gal) }\end{array}$ & $\begin{array}{l}\text { Renewable Fuel Retailer Tax } \\
\text { Incentive: Payment to retail dealers } \\
\text { of motor fuels for sales of ethanol } \\
\text { conditional on meeting or exceeding } \\
\text { threshold (sales of renewable fuel as } \\
\text { a } \% \text { of total gasoline sales); } \\
\text { threshold increases incrementally } \\
\text { each year from } 14 \% \text { in } 2013 \text { to } 25 \% \\
\text { beginning on } 1 \text { January } 2024 ; \\
\text { expires end- } 2025 \text {. }\end{array}$ & $\begin{array}{l}\text { up to USD } 0.025 \\
\text { (USD 0.095/gal) }\end{array}$ & $\begin{array}{l}\text { Incentive for retail dealer selling or } \\
\text { dispensing biodiesel: Includes } \\
\text { additional payment to that under the } \\
\text { Renewable Fuel Retailer Tax } \\
\text { Incentive (which applies also to } \\
\text { biodiesel) for sales of biodiesel } \\
\text { conditional on meeting or exceeding } \\
\text { threshold (sales of biodiesel as a \% } \\
\text { of total gasoline sales); threshold } \\
\text { increases incrementally each year } \\
\text { from } 10 \% \text { in } 2013 \text { to } 25 \% \text { beginning } \\
\text { on } 1 \text { January } 2024 \text {; expires end- } \\
2025 \text {. }\end{array}$ \\
\hline Maine & - & - & $\begin{array}{c}\text { USD } 0.007 \\
\text { (USD } 0.025 / \text { gal) }\end{array}$ & $\begin{array}{l}\text { Excise tax reduction only for } \mathrm{B} 90 \text { - } \\
\text { B100. }\end{array}$ \\
\hline Michigan & $\begin{array}{l}\text { USD } 0.0185 \\
\text { (USD } 0.07 / g a l)\end{array}$ & For E70 and above. & $\begin{array}{l}\text { USD } 0.008 \\
\text { (USD 0.03/gal) }\end{array}$ & For B5 and above. \\
\hline Minnesota & $\begin{array}{c}\text { USD } 0.0215 \\
\text { (USD } 0.0825 / \mathrm{gal})\end{array}$ & For E85 only. & - & - \\
\hline
\end{tabular}


Table A.7. Tax preferences on retail sales of ethanol and biodiesel in OECD and non-OECD EU countries

\begin{tabular}{|c|c|c|c|c|}
\hline \multirow{2}{*}{ Country } & \multicolumn{2}{|r|}{ Ethanol } & \multicolumn{2}{|r|}{ Biodiesel } \\
\hline & Local currency & Comment & Local currency & Comment \\
\hline New York & $\begin{array}{l}\text { USD } 0.1125 \\
\text { (USD 0.426/gal) }\end{array}$ & $\begin{array}{l}\text { Exemption from state sales and use } \\
\text { taxes for E85 only. }\end{array}$ & $\begin{array}{c}\text { USD } 0.0216 \\
\text { (USD } 0.0817 / \mathrm{gal})\end{array}$ & $\begin{array}{l}20 \% \text { reduction in sales and use taxes } \\
\text { applied to diesel on B20 blend; in } \\
\text { effect until } 1 \text { September } 2014 \text {. }\end{array}$ \\
\hline North Dakota & - & - & $\begin{array}{l}\text { USD } 0.0132 \\
\text { (USD } 0.05 / \mathrm{gal})\end{array}$ & $\begin{array}{l}\text { Biodiesel Blender Tax Credit: Income } \\
\text { tax credit for licensed fuel suppliers } \\
\text { who blend biodiesel or green diesel } \\
\text { with diesel fuel containing at least } \\
5 \% \text { biodiesel or green diesel (B5). }\end{array}$ \\
\hline South Dakota & $\begin{array}{l}\text { USD } 0.037 \\
\text { (USD } 0.14 / \mathrm{gal})\end{array}$ & Reduction in fuel-excise tax rate. & $\begin{array}{l}\text { USD } 0.0052 \\
\text { (USD 0.02/gal) }\end{array}$ & $\begin{array}{l}\text { Reduction in fuel-excise tax rate on } \\
\text { B5 or above once a biodiesel } \\
\text { production facility in the state } \\
\text { reaches a name-plate capacity of at } \\
\text { least } 20 \text { million gallons per year and } \\
\text { fully produces at least } 10 \text { million } \\
\text { gallons of biodiesel within one year. }\end{array}$ \\
\hline Texas & - & - & $\begin{array}{l}\text { USD } 0.0528 \\
\text { (USD } 0.020 / \text { gal) }\end{array}$ & $\begin{array}{l}\text { Exemption from diesel tax. Also } \\
\text { applies to the volume of water, fuel } \\
\text { ethanol blended with diesel. }\end{array}$ \\
\hline Washington & $\begin{array}{c}0.471-0.484 \% \text { of } \\
\text { sales value }\end{array}$ & $\begin{array}{l}\text { Deduction for "business and } \\
\text { occupation tax" taxes paid on the } \\
\text { sale or distribution of E85. }\end{array}$ & $\begin{array}{l}0.471-0.484 \% \text { of } \\
\text { sales value }\end{array}$ & $\begin{array}{l}\text { Deduction for "business and } \\
\text { occupation tax" taxes paid on the } \\
\text { sale or distribution of biodiesel. }\end{array}$ \\
\hline
\end{tabular}

.. : Not known.

1. The system used by the federal government of the United States functions like an excise-tax exemption, but is formally an income-tax credit. Tax credits are worth more to recipients than excise-tax exemptions, however, because the former are not taxed as corporate revenue.

Data Sources:

Argentina: Almada (2008)

Australia: Australian Taxation Office (http://www.ato.gov.au/businesses/pathway.aspx?pc=001/003/095).

Canada: Evans and Dessureault (2012); International Fuel Tax Association, Inc. (www.iftach.org); Nova Scotia, Canada: Financial Measures Act (http://nslegislature.ca/legc/bills/59th_2nd/1st_read/b097.htm\#s41).

EU: European Commission

(http://ec.europa.eu/taxation_customs/resources/documents/taxation/excise_duties/energy_products/rates/excise_duties-

part_ii_energy_products_en.pdf) and Union of European Petroleum Independents (www.upei.org/release/Matrix_Biofuels.pdf).

France: Ministère de l'Ecologie, du Développement durable et de l'Energie (www.developpement-

durable.gouv.fr/IMG/pdf/15_La_fiscalite_des_produits_petroliers_et_gaziers.pdf).

Japan: Ministry of Economy, Trade and Industry (http://www.cao.go.jp/zei-cho/youbou/2013/doc/meti/25y_meti_k_30.pdf).

New Zealand: Ministry of Transport (http://www.transport.govt.nz/ourwork/climatechange/biofuels/).

Switzerland: Confédération Suisse (http://www.admin.ch/opc/fr/classified-compilation/19960585/).

United States: US Department of Energy, Alternative Fuels and Advanced Vehicle Data Center (www.afdc.energy.gov) and related links for statelevel policies; US Department of Transportation, Motor Fuel \& Highway Trust Fund, "Monthly Motor Fuel Reported by States"

(http://www.fhwa.dot.gov/policyinformation/motorfuelhwy_trustfund.cfm); International Fuel Tax Association, Inc. (www.iftach.org).

In the mid-2000s, several of Canada's Provinces created their own excise-tax exemptions for ethanol, and British Columbia, Manitoba, and Ontario exempted the biodiesel proportion of fuel blends from their fuel-excise taxes. A few also exempted biofuels from provincial sales taxes. However, in certain cases, some of these biofuel tax exemptions were repealed. Specifically, Ontario and Alberta repealed their ethanol tax exemptions in 2007, and the federal government did so for both ethanol and biodiesel in 2008. Around the same time, producers of such fuels were provided with payments linked to their production. In the United States, preferences are typically around USD 0.05 per litre of pure biofuel blended but exceed USD 0.10 per litre in a few states. Several states also exempt biofuels or biofuel blends from state sales taxes (similar to VAT in other countries) which are normally applied to petroleum fuels. 
The European Union, under the Energy Tax Directive, sets minimum tax rates that its Member States have to apply, but otherwise it applies no Community-wide excise tax on transport fuels: this is within the competence of the Member States. It does, however, authorise its Member States to grant tax preferences to biofuels, within limits. Exemptions or reductions from fuel-excise taxes, expressed on a pure biofuel-equivalent basis, range up to EUR 0.67 (USD 0.90) per litre, with many in the neighbourhood of EUR 0.30-0.40 (USD 0.40-0.55) per litre. While several EU Member States consider that their biofuel supply requirements do not alone provide adequate support for the sector, and therefore couple this obligation with partial or full excise-tax exemptions, an increasing number of them have decided to abolish, reduce or restrict tax privileges for some biofuels. Germany, for example, limits this benefit to specific types of biofuels such as E85.

Several countries - among which France and Italy — have opted for a production-quota system, whereby tax relief is granted only on the agreed amount of production from approved operators. A few other countries provide tax relief for an unlimited quantity of biofuels. Since tax concessions are considered as state aids in the European Union, they must be notified to and authorised by the Commission. The majority of member states have notified taxexemption schemes and the Commission has approved all the requests it has received to date. Exemptions are usually granted for a fixed period of six years, and can be renewed.

Discrimination in favour of domestic producers or feedstocks is not uncommon. Australia applies its national fuel-excise tax equally to domestically produced as well as imported ethanol, but then provides a grant to domestic producers that exactly offsets the excise tax; such grants are not available for imports. In Canada, the Province of Nova Scotia exempts from provincial-level fuel-excise taxes only biodiesel that is produced in the province. In $E U$ Member States that auction annual quotas for biofuel deliveries, and then grant those biofuels exemption from fuel-excise taxes, participation in these auctions has been mainly by EU suppliers. In the US State of Montana, "A licensed distributor who pays the special fuel tax on biodiesel may claim a refund equal to USD 0.02 per gallon [USD 0.0053 per litre] of biodiesel sold during the previous quarter if the biodiesel is produced entirely from biodiesel components made in Montana". In addition, "[t] he owner or operator of a retail motor fuel outlet may claim a refund equal to USD 0.01 per gallon [USD 0.00264 per litre] of biodiesel purchased from a licensed distributor if the biodiesel is created entirely from biodiesel components produced in Montana" (USDOE/AFDC, 2013).

The trend in these countries, however, has been to move away from fuel-tax exemptions or reductions, and towards volumetric (i.e. per litre or gallon) subsidies or consumption mandates, and in some countries even both. The US Federal Government, for example, pays fuel blenders a tax credit of USD 1 per gallon (USD 0.264 per litre) of pure biodiesel, agribiodiesel, or renewable diesel blended with petroleum diesel between 1 January 2005 and 31 December 2013 that results in a mixture containing at least $0.1 \%$ diesel fuel. ${ }^{66}$ One motivation has been to reduce the cost to the public purse, especially where fuel-excise taxes are the main source of funding for highway construction or maintenance.

Several countries allocate access to excise-tax exemptions through auctions or public tenders that explicitly or effectively favour domestic producers. Brazil's system for supporting biodiesel, for example, is regulated through periodic auctions (the $31^{\text {st }}$ auction was held in June 2013) in which only domestic producers participate. Preference is given to producers who have earned the Social Fuel Stamp, a domestic certification programme aimed at encouraging production of biodiesel feedstocks by poorer (family) farmers in disadvantaged areas. Producers who qualify for the Social Food Stamp also qualify for tax incentives and better credit terms (Barros, 2012). In France, quotas for biofuels qualifying for 
tax exemptions have long been allocated through public tenders (Kutas et al., 2007). Other EU Member States can participate in the tenders, but to date no non-EU suppliers have. In April 2012, the government of Spain issued an Executive Order to allocate biodiesel quotas exclusively to EU-based biodiesel producers; several third-country exporters alleged that this new system effectively restricted their access to Spain's domestic biodiesel market (see Flach et al., 2012), and in October 2012 Spain reversed its earlier decision (Sapp, 2012).

Argentina's Law 26,093 of April 2006, which regulates and promotes the production and use of biofuels, empowers various government entities to intervene heavily in the domestic market for biofuels (Joseph, 2012). Each year the Secretariat of Energy establishes the volumes of biofuels needed to comply with the law, determines and modifies the percentage blend levels, sets the prices of biofuels in the domestic market, establishes volumes, and approves exports. Biofuels governed by this regime are exempt from three taxes on petroleum fuels: the 20\% Impuesto a los Combustibles Liquidos y Gaseosos (ICLG), or hydrocarbon tax; the 20\% "tasa de gasoil" (diesel tax); and the 19\% "tasa hidrica" (gasoline tax) (Almada, 2008). To be eligible for these and other incentives, companies have to operate in Argentina and be dedicated exclusively to the production of one or more biofuels. Moreover, the majority of the company's equity must be controlled either by an Argentine government (national, provincial, or municipal) or by an agricultural producer or producers' co-operative. Priority in the allocation of supply quotas is given to small and medium-size enterprises, farmers, and entities that operate in non-traditional production locations. For example, in 2010 the Argentine government purchased all the biodiesel produced by small companies (around 300000 tonnes) and then distributed the remaining 560000 tonnes needed to meet the domestic quota among the big biodiesel exporters (Valente, 2010).

\section{Regulated volumes}

Over the last five years, countries accounting for a large proportion of the liquid transport fuel consumed in the world have set minimum required amounts of "renewable fuels" consumed neat or as components of ethanol-gasoline or biodiesel-diesel blends (Tables A.8 and A.9). ${ }^{67}$ Some of these mandated shares or volumes provide a floor on the amount consumed. Others, such as those set by the US Federal Government and some EU Member States, by creating incentives only for volumes sold up to the target amount also effectively (but not legally) reduce the incentive to sell biofuel volumes above the mandated amount. However, in all cases - e.g. at times when biofuel prices are low relative to petroleumproduct prices - no regulations prohibit the use of more than the minimum required total volumes. Rather, separate fuel-quality regulations typically limit the percentage of biofuels that may be incorporated into blended fuels.

67. Several countries have also established non-binding indicative targets. For example, on 9 July 2011, an Australian conglomerate that includes the Commonwealth Scientific and Industrial Research Organisation (CSIRO), Virgin Airways, Qantas, Air New Zealand, Boeing, and the Defence Science Technology Organisation of Australia's Defence Department, committed to a plan to use biofuels to supply $5 \%$ of the fuel used by Australasian commercial airlines by 2020, expanding to $40 \%$ in 2050 . 
DOMESTIC INCENTIVE MEASURES FOR RENEWABLE ENERGY WITH POSSIBLE TRADE IMPLICATIONS

Table A.8. Minimum mandated volumes or blend ratios for ethanol and biodiesel in OECD countries, as of end July 2012

\begin{tabular}{|c|c|c|c|c|}
\hline \multirow[b]{2}{*}{ Country } & \multicolumn{2}{|c|}{$\begin{array}{c}\text { Renewable alternatives to gasoline } \\
\text { (e.g. ethanol) }\end{array}$} & \multicolumn{2}{|c|}{$\begin{array}{l}\text { Renewable alternatives to diesel } \\
\text { (e.g. biodiesel) }\end{array}$} \\
\hline & Current & Future & Current & Future \\
\hline Australia (federal) & - & - & - & - \\
\hline New South Wales & $4 \%$ & $4 \%$ & $2 \%$ & $\begin{array}{l}5 \% \\
\text { (once there is sufficient local } \\
\text { production) }\end{array}$ \\
\hline Canada (federal) & $5 \%$ & $5 \%$ & $2 \%$ & $2 \%$ \\
\hline British Columbia & $5 \%$ & $5 \%$ & $4 \%$ & $4 \%$ \\
\hline Alberta & $5 \%$ & $5 \%$ & $2 \%$ & $2 \%$ \\
\hline Saskatchewan & $7.5 \%$ & $7.5 \%$ & $2 \%$ & $2 \%$ \\
\hline Manitoba & $8.5 \%$ & $8.5 \%$ & $2 \%$ & $2 \%$ \\
\hline Ontario & $5 \%$ & $5 \%$ & - & - \\
\hline Quebec & - & $\begin{array}{l}5 \% \text { ethanol in gasoline } \\
\text { (target only) }\end{array}$ & - & - \\
\hline European Union & \multicolumn{4}{|c|}{$\begin{array}{l}\text { In } 2020 \text {, at least } 10 \% \text { of all transport fuels (excluding those used in aviation) must be derived from renewable } \\
\text { sources. Not only biofuels, but also renewable electricity and hydrogen may count towards achieving the target. }\end{array}$} \\
\hline Japan & \multicolumn{4}{|c|}{ Rising from $2.6 \times 10^{8}$ (in 2010) to $5 \times 10^{8}$ litres (in 2018) } \\
\hline Korea & - & - & $2 \%$ & $5 \%$ (long-term) \\
\hline Mexico & $2 \%$ in Guadalajara & $\begin{array}{l}2 \% \text { (from 2012) also } \\
\text { in Mexico City and Monterrey }\end{array}$ & - & - \\
\hline Turkey & $2 \%$ (in 2013) & $3 \%$ (from 2014) & & \\
\hline \multicolumn{5}{|l|}{ United States } \\
\hline \multicolumn{5}{|l|}{ Federal } \\
\hline Biomass-based diesel & - & - & $\begin{array}{l}4.85 \times 10^{9} \\
\text { litres }\end{array}$ & $\begin{array}{l}\text { At least } 3.8 \times 10^{9} \text { litres }(2012- \\
22)\end{array}$ \\
\hline $\begin{array}{l}\text { Other advanced } \\
\text { biofuels }^{2}\end{array}$ & \multicolumn{4}{|c|}{ Rising from $3.14 \times 10^{9}$ litres (in 2013) to $18.9 \times 10^{9}$ litres (in 2022) } \\
\hline Cellulosic biofuels & \multicolumn{4}{|c|}{ Rising from $53 \times 10^{6}$ litres (proposed for 2013) to $60.6 \times 10^{9}$ litres (in 2022) } \\
\hline $\begin{array}{l}\text { Other (mainly derived } \\
\text { from corn starch) }\end{array}$ & $52.2 \times 10^{9}$ litres (in 2013) & $\begin{array}{l}56.8 \times 10^{6} \text { litres } \\
\quad \text { (in 2022) }\end{array}$ & - & - \\
\hline \multicolumn{5}{|l|}{ State } \\
\hline Florida & $10 \%$ & $10 \%$ & & \\
\hline Hawaii & $\begin{array}{l}\text { At least } 85 \% \text { of gasoline } \\
\text { must contain a minimum of } \\
10 \% \text { ethanol. }\end{array}$ & $\begin{array}{c}\text { At least } 85 \% \text { of gasoline must } \\
\text { contain a minimum of } 10 \% \\
\text { ethanol. }\end{array}$ & & \\
\hline Louisiana & - & $2 \%{ }^{1}$ & - & $2 \%{ }^{1}$ \\
\hline Minnesota & $10 \%$ & $20 \%$ (from Aug 2013) & $5 \%$ & $\begin{array}{c}\text { During months of April- } \\
\text { October: } 10 \% \text { (from May } \\
2012 \text { ) and } 20 \% \text { (from May } \\
\text { 2015) }\end{array}$ \\
\hline Missouri & $10 \%$ & - & - & - \\
\hline Oregon & $10 \%$ & $10 \%$ & $5 \%$ & $5 \%$ \\
\hline Pennsylvania & - & $10 \%$ cellulosic ethanol $^{1}$ & $2 \%$ & $2 \%$ \\
\hline Washington & $2 \%$ & $2 \%$ & $2 \%$ & $5 \%{ }^{1}$ \\
\hline
\end{tabular}




\section{Notes to Table A.8}

1. Blending requirement becomes operational after in-state production or production capacity (depending on the state) of the biofuel equals or exceeds a minimum monthly or annual volume.

2. Equal to the volume of "Advanced biofuel" mandated, minus the volumes of "Cellulosic biofuel" and 1.5 times the "Biomass-based diesel" mandated. All volumes are ethanol-equivalent, except for biomass-based diesel which is actual.

3. Equal to the volume of "Renewable fuel" mandated, minus the volume of "Advanced biofuel" mandated.

Sources: Lane (2011 and 2012); Wisner (2013); and

Australia (New South Wales): Office of Biofuels (http://www.biofuels.nsw.gov.au/)

Canada: Canadian Renewable Fuels Association (http://www.greenfuels.org/en/public-policy/provincial-programs.aspx) and links to provincial programmes.

EU: European Commission (http://ec.europa.eu/energy/renewables/biofuels/biofuels_en.htm)

United States: US Environmental Protection Agency, "40 CFR Part 80 - Regulation of Fuels and Fuel Additives: 2013 Renewable Fuel Standards; Proposed Rule", Federal Register, Vol. 78, No. 26, 7 February 7, 2013, pp. 9282-9306; and US Department of Energy, Alternative Fuels Data Center (http://www.afdc.energy.gov/laws/state).

Table A.9. Mandated volumes or blend ratios for ethanol and biodiesel in non-OECD countries, as of end 2012

\begin{tabular}{|c|c|c|c|c|}
\hline \multirow{2}{*}{ Country } & \multicolumn{2}{|r|}{ Ethanol } & \multicolumn{2}{|c|}{ Biodiesel } \\
\hline & Current & Future & Current & Future \\
\hline Angola & $10 \%$ & $10 \%$ & - & - \\
\hline Argentina & $10 \%$ & $10 \%$ & $7 \%$ & $10 \%$ (from 2015) \\
\hline Brazil & $18-25 \%$ & $18-25 \%$ & $2 \%$ & $\begin{array}{l}7 \% \text { (from } 2013 \text { ), } 10 \% \text { (from } \\
2014 \text { ), } 20 \% \text { (from 2020) }\end{array}$ \\
\hline China & $10 \%$ in 9 provinces & $10 \%$ countrywide (by 2020 ) & - & - \\
\hline Colombia & $8 \%$ & Could rise to $10 \%$ (by 2020) & - & - \\
\hline Costa Rica & $7 \%$ & $7 \%$ & $20 \%$ & $20 \%$ \\
\hline Ethiopia & $5 \%$ in Addis Ababa & $10 \%$ in Addis Ababa & - & - \\
\hline Fiji & $10 \%$ voluntary & $10 \%$ mandatory being considered & $5 \%$ voluntary & $\begin{array}{l}5 \% \text { mandatory being } \\
\text { considered }\end{array}$ \\
\hline India & $5 \%$ & $\begin{array}{c}10 \% \text { (once domestic production } \\
\text { capacity in place) }\end{array}$ & - & $20 \%$ \\
\hline Indonesia & $3 \%$ (intermittent) & $3 \%$ (intermittent) & $2.5 \%$ (intermittent) & $2.5 \%$ (intermittent) \\
\hline Jamaica & $10 \%$ & $10 \%$ & - & - \\
\hline Kenya & $10 \%$ in Kisumu & $10 \%$ in Kisumu & - & - \\
\hline Malaysia & - & - & $\begin{array}{l}5 \% \text { in central region } \\
\text { only }\end{array}$ & $\begin{array}{c}10 \% \text { country-wide by June } \\
2014\end{array}$ \\
\hline Malawi & $10 \%$ & $10 \%$ & & \\
\hline Mozambique & $10 \%$ & $10 \%$ & being considered & being considered \\
\hline Panama & $2 \%$ & $\begin{array}{l}5 \% \text { (from April 2014), } \\
\text { rising to } 10 \% \text { (in 2016) }\end{array}$ & - & - \\
\hline Paraguay & $24 \%$ & $24 \%$ & $1 \%$ & $1 \%$ \\
\hline Peru & $7.8 \%$ & $7.8 \%$ & $2 \%$ & $5 \%$ \\
\hline Philippines & $10 \%$ & $10 \%$ & $2 \%$ & $2 \%$ \\
\hline South Africa & $10 \%$ & $10 \%$ & $5 \%$ & $5 \%$ \\
\hline Sudan & $5 \%$ & $5 \%$ & - & - \\
\hline Chinese Taipei & - & $3 \%$ under consideration & $1 \%$ & $1 \%$ \\
\hline Thailand & - & - & $5 \%$ & $5 \%$ \\
\hline Uruguay & - & $5 \%$ (from 2015) & $2 \%$ (voluntary) & $5 \%$ (from 2015) \\
\hline $\begin{array}{l}\text { Viet Nam } \\
\text { (in some big cities) }\end{array}$ & $5 \%$ & $5 \%$ & - & - \\
\hline Zimbabwe & - & $20 \%$ being considered & 一 & - \\
\hline
\end{tabular}

Source: OECD Secretariat, based on Lane (2011 and 2012) and updates; Adnan (2013) and other sources. 
Some of the mandates do not discriminate by type of biofuel, but many are specific to either ethanol or biodiesel; most are expressed as overall or average blending rates, while those established at the federal level in the United States specify actual volumes. No specific blending mandates have yet been established for aviation biofuels, but several OECD countries allow aviation biofuels to be credited against mandated volumes of biofuels either for biodiesel or biofuels generally. Generally, where specific blending targets or requirements are established, those for ethanol are more commonplace than for biodiesel, and they tend to be set at higher levels than for biodiesel. However, biodiesel is often favoured in countries and sub-national jurisdictions with significant production of palm oil, soybean oil or canola oil, and where diesel fuel dominates the transport-fuel mix.

The most significant biofuel mandates - if only because of the volumes implied - are those of Brazil, the United States, and the European Union. Typically, establishing a biofuel content mandate has necessitated writing complex regulations and creating a considerable amount of bureaucracy to administer them. Not only do blenders or merchants have to register and report the volumes of biofuels they have sold or incorporated into fuel blends, but procedures have had to be developed for dealing with collective or individual failure to meet the target volumes or blending percentages. In many jurisdictions, penalties apply in the case of non-compliance. In some, tradable credits have been created, allowing companies that cannot easily comply with the regulations to purchase surplus credits from companies that can.

The European Union's Renewable Energy Directive (RED) ${ }^{68}$ established a mandatory requirement of $10 \%$ renewable energy consumed in transport by 2020 , of which $30 \%$ of the requirement can be met by electric cars or trains. Fulfilment of the standards for liquid biofuels is linked to minimum sustainability criteria (see below). A separate Directive (2009/30/EC), which amended Directive 98/70/EC on environmental quality standards for fuel (the Fuel Quality Directive, FQD), requires suppliers of fuel to reduce the life-cycle emissions of greenhouse gases (GHGs) from transport fuel use by $6 \%$ by 2020 . The FQD also incorporated sustainability criteria for biofuels used to meet the GHG-reduction requirement. Together, the RED and the FQD are expected to lead to a substantial increase in the use of biofuels in the European Union.

The US mandate (the Renewable Fuels Standard) was first established in the Energy Policy Act of 2005 and then revised under the Energy Independence and Security Act of 2007 (EISA 2007). EISA 2007 establishes an overall blending mandate for biofuels ("RFS2"), and further sub-divides it into four, somewhat overlapping sub-mandates. These relate to:

- Renewable biofuel: fuel that is produced from any renewable biomass and that is used to replace or reduce the quantity of fossil fuel present in transportation fuel;

- Advanced biofuel: renewable fuel, other than ethanol derived from corn starch (starch derived from maize) $;^{69}$ within this category are two major sub-categories:

- Biomass-based diesel: renewable fuel that is biodiesel as defined in the EPAct, including any diesel-fuel substitutes made from biomass feedstocks including biodiesel (mono-alkyl esters) and non-ester renewable diesel (cellulosic diesel);

68. Directive 2009/28/EC of 23 April 2009 on the promotion of the use of energy from renewable sources.

69. This can include ethanol derived from cellulose, hemi-cellulose, or lignin, ethanol derived from sugar or starch other than corn starch, ethanol derived from waste material, including crop residues, other vegetative waste material, animal waste, and food waste and yard waste, biomass-based diesel, biogas and butanol or other alcohols produced through the conversion of organic matter from renewable biomass, and other fuel derived from cellulosic biomass. 
- Cellulosic biofuel: renewable fuel derived from any cellulose, hemicelluloses or lignin that is derived from renewable biomass; qualifying fuels include cellulosic-biomass ethanol and any biomass-to-liquid (BTL) fuel substitutes for gasoline, diesel fuel or jet kerosene;

- Other advanced biofuels: these include ethanol from non-corn starch, ethanol from sugars, ethanol from waste materials, and biobutanol.

State and provincial-level biofuel mandates have been established by several sub-national jurisdictions in Australia, Canada and the United States, often at higher levels than those in force at the time at the federal level, or even before a federal mandate existed. Australia's state-level mandates are the only ones in that country, which has so far refrained from establishing a nation-wide mandate. In Canada, three provinces (Saskatchewan, Ontario and Quebec) had already established blending or volumetric requirements for biofuels prior to the announcement of the federal renewable fuel standards (RFS) in December 2006. Currently, only British Columbia's mandate for biodiesel, and Manitoba's and Saskatchewan's mandates for ethanol, are higher than the national average.

As in Canada, several sub-national governments in the United States preceded the federal government in establishing their own biofuel mandates. The US State of Minnesota, for example, announced in 2003 that it would require 10\% of gasoline consumption in 2010 be met by ethanol and that $2 \%$ of diesel consumption in 2005 be met by biodiesel. Subsequently, at least eight other states (as well as several cities) have established, or announced their intention to establish, their own biofuel-content requirements.

Several Canadian provinces (British Columbia, Saskatchewan, Manitoba and Quebec) and US states (Louisiana, Montana, Oregon and Washington) have linked implementation of their biofuel-content mandates with the development of in-state or in-province manufacturing capacity for the mandated fuel. For example, Washington State stipulated that, before for its mandate went into effect, a positive determination would have to be made by the Director of the State Department of Ecology that feedstock grown in Washington State could satisfy a 2\% biodiesel blending requirement. The biodiesel requirement was increased to $5 \%$ once in-state feedstocks and oil-seed crushing capacity were determined to be able to meet the needs of a 3\% average blend. In addition, many countries, including Argentina, Brazil, Indonesia, Paraguay and Thailand, adjust their required blending levels in line with changes in domestic production. For example, the Government of Brazil has lowered its required ethanol blend on at least eight occasions - most recently in April 2011 in response to declining domestic production - since the Pró-Álcool programme was launched in $1975 .^{70}$ One effect of such abrupt policy adjustments is to create uncertainty for importers.

A few jurisdictions have gone further than this. For example, under the Philippines' mandatory E10 blend, which went into effect in July 2011, imported ethanol may be used to meet the requirement only until July 2015. From that date onwards, however, imports will be allowed only to make up for shortfalls in local production. Current ethanol production in the Philippines covers less than one-third of the volume required to meet the previous $5 \%$ ethanol requirement (Lane, 2011). More recently, Turkey created a new obligation on gasoline refiners, fuel blenders and distributors to ensure that, starting 1 January 2013, all gasoline sold in the country contains 2\% ethanol by volume, increasing to 3\% starting 1 January 2014. Obligated parties are required to use only domestically produced ethanol. ${ }^{71}$

70. See Government of Brazil, Law No. 8723 of 28 October 1993, available at: www.planalto.gov.br/ccivil_03/leis/L8723.htm.

71. Government of Turkey, "Benzin türlerine etanol harmanlanması kakkında tebliğ [Regulation on ethanol blending requirement for gasoline]”, Resmî Gazete, 7 July 2012. 
Ethanol-production plants operating in the US State of Louisiana and deriving their fuel "from the distillation of corn [maize] must use corn crops harvested in Louisiana to meet at least $20 \%$ of the facility's total feedstock requirement. Renewable-fuel plants operating in Louisiana and deriving biodiesel from soybeans and other crops must use soybean crops harvested in Louisiana to meet at least $2.5 \%$ of the facility's total feedstock requirement. In succeeding years, the minimum percentage of Louisiana-harvested corn and soybeans used to produce renewable fuel in Louisiana facilities must be at least the same percentage of corn and soybeans used nationally to produce renewable fuel" (USDOE/AFDC, 2013).

\section{Sustainability standards ${ }^{72}$}

In recent years, several OECD countries have established government measures requiring that biofuels meet minimum levels of reduction in life-cycle GHG emissions, compared with the petroleum products they replace, and related sustainability standards (often elaborated outside the government), in order for them to satisfy domestic regulations mandating the use of specific volumes of biofuels or to benefit from subsidies or excise-tax exemptions. They generally take the form of measurable sustainability criteria and a series of minimum quantitative or qualitative indicators to establish whether a given product meets the criteria. These provisions are to a certain extent supported by non-governmental initiatives to develop biofuel sustainability standards that include environmental, social and economic principles and criteria, and related third-party certification.

Switzerland was the first country to implement sustainability standards for biofuels. The regulations ${ }^{73}$ exempt fuels produced from renewable feedstock from the mineral oil tax; provided it can be proven that they have a positive aggregate environmental impact and are produced under socially acceptable conditions. In order to qualify for the exemption, manufacturers or importers need to provide information on the entire process of production, transportation and distribution of the products, so as to allow the Federal officials ${ }^{74}$ to establish the aggregate environmental impact of the product through environmental life-cycle assessment (LCA) and an assessment of its potential threats to biodiversity. Minimum lifecycle emission requirements in order to qualify for the exemption are set at $40 \%$ less GHG than the life-cycle emissions of the fossil fuels that the biofuels replace. In addition, fuels from renewable sources should not harm the environment significantly more than fossil fuels and should not endanger tropical forest preservation and biological diversity. Information provided by the applicant is balanced against impact data in the Ecoinvent ${ }^{75}$ and other equivalent databases, based on the ecological-scarcity method or other equivalent methods. ${ }^{76}$ Biofuels covered by the exemption include ethanol, biodiesel, biogas, biomethanol, dimethyl bio-ether, biohydrogen, synthetic biofuels and vegetable or animal oils used for fuel.

The Federal Council determines annually the quantity of biofuels eligible for the exemption on the basis of a number of considerations, including their contribution to energypolicy objectives and their relative price compared with fossil fuels. Exemptions are attributed on a first-request, first served basis until the annual quantity determined by the Federal

72. This section draws heavily on Moïsé and Steenblik (2011).

73. The Mineral Oil Taxation Act (MinOTA), Ordinance (MinOTO) and Biofuels Life-Cycle Assessment Ordinance (BLCAO).

74. In the Office of the Environment (FOEN), the Federal Customs Administration and the State Secretariat for Economic Affairs (SECO).

75. Www.ecoinvent.ch.

76. See Federal Office for the Environment FOEN, The Ecological Scarcity Method: Eco-Factors 2006 - A method for impact assessment in LCA. 
Council has been covered. Attributed tax reliefs and exemptions are valid over a period of four years, unless the prerequisite conditions are no longer satisfied.

The primary sustainability criterion in the EU's RED is a required GHG emission-saving value compared with fossil fuel of at least 35\%, brought to 50\% from 2017 onwards and to $60 \%$ from 2018 onwards for biofuels produced in newly launched installations. This is the only criterion that biofuels produced from waste and residues must meet. ${ }^{77}$ For other biofuels, additional criteria relate to the protection of land biodiversity and the preservation of land with high carbon stock. Raw materials used to produce biofuels should not be obtained from land that had a high biodiversity value in January 2008, including: (a) primary forest and other wooded land hosting native species and ecological processes not significantly disturbed; (b) areas designated for nature protection purposes, or for the protection of rare, threatened or endangered ecosystems or species, unless evidence is provided that their production does not interfere with these purposes; (c) highly biodiverse grasslands. Furthermore, raw materials used to produce biofuels should not be obtained from land that had high carbon stocks in January 2008, including wetlands and continuously forested areas with significant canopy cover, or from peatland, unless evidence is provided that the cultivation and harvesting does not involve drainage of previously undrained soil.

Agricultural raw materials cultivated in the European Union and used to produce biofuels should also comply with EU environmental requirements for agriculture. Although such criteria do not apply to imports from third countries, under the Directive the European Union is to encourage the development of multilateral and bilateral agreements and voluntary international or national schemes that cover key environmental and social considerations, in order to promote the production of biofuels and bioliquids worldwide in a sustainable manner. Only biofuels that comply with sustainability criteria count against biofuels targets and renewable-energy obligations, and are eligible for financial support for the consumption of biofuels and bio-liquids. In October 2012, in connection with its proposed cap of 5\% on the amount of crop-based biofuels that could qualify under the Renewable Energy Directive, the European Commission suggested ending public subsidies for biofuels after 2020, except in cases where producers could demonstrate "substantial greenhouse gas savings".

The categorisation of biofuels under the United States' Energy Independence and Security Act of 2007 allows for the introduction of specific life-cycle emission reduction standards for different products (at least $20 \%$ of GHG reduction for renewable fuels, $50 \%$ for advanced biofuels and biomass-based diesel, and $60 \%$ for cellulosic biofuels). The calculation of GHG reduction is based on an LCA of emissions, including direct emissions and significant indirect emissions, such as those resulting from land-use change, and including all stages of fuel and feedstock production and distribution, from feedstock cultivation or extraction through the distribution, delivery and use by the ultimate consumer, adjusting values to account for the relative global warming potential of the gases emitted.

\section{Indirect support for distribution and use}

Ethanol and biodiesel are similar, but not identical, to their petroleum analogues, gasoline and diesel fuel. Ethanol is hydroscopic and corrosive, hence any storage vessel, pipeline, pump or automobile fuel-system component must be able to cope with these properties. In the case of biodiesel, the different possible feedstocks from which it can be made result in fatty acid methyl esters that differ slightly in their chemical and physical properties, particularly viscosity at low temperatures. By contrast, aviation biofuels have been designed from the start to be "drop-in" fuels, and require no modifications to jet engines or storage facilities. However, because there is currently a limit on the share of aviation biofuel in blends with

77. With the exception of agricultural, aquaculture, fisheries and forestry residues. 
petroleum-derived jet kerosene (50\%), airlines that use aviation biofuel prefer to store it separately.

Having deemed biofuels to be desirable, several OECD and non-OECD countries are subsidising or mandating investments in biofuel storage, transport and distribution infrastructure, and instructing government agencies to procure vehicles capable of operating on high blends of biofuels. The bulk of this government support has been directed at ethanol, because the handling of ethanol typically necessitates expensive investments in new equipment. There is also a strongly held view in many governments that ethanol faces a chicken-and-egg problem: greater penetration of E85 in the market (and vehicles capable of running on it) will not occur until there is a sufficient density of distribution points, and growth in ethanol production will soon be constrained unless more and more consumers start using ethanol in high-percentage blends. This blend wall - the limit on the amount of ethanol allowed in fuel use by vehicles that are not flex fuel, which currently stands at $10 \%$ by volume - has already effectively been reached in the United States.

Both the European Union and its Member States and the United States (both the federal government and individual states), offer incentives to develop infrastructure for storing and distributing biofuels. Among EU member countries, the United Kingdom from 2005-11 provided funds to encourage organisations and firms to install alternative refueling stations through its Alternative Fuels Infrastructure Grant Programme (Cenex, 2011). The grants, funded by the Department of Transport, covered up to 50\% of the eligible costs for new or refurbished fuelling stations dispensing fuels from alternative sources (including equipment for biogas). Sweden obliges its bigger filling stations to sell fuel from renewable sources.

Between 2006 and the end of 2011, the US Federal Government offered an "Alternative Fuel Infrastructure Tax Credit" to help cover the cost of equipment for handling alternative fuels, including E85 and diesel fuel blends containing a minimum of $20 \%$ biodiesel. The credit amount was up to $30 \%$ of the cost, not to exceed USD 30000 per facility. A separate incentive, under the Rural Energy for America Program (REAP), provides loan guarantees and grants to agricultural producers and rural small businesses to purchase renewable-energy systems. Eligible renewable energy systems include blender pumps capable of dispensing intermediate ethanol blends. The maximum loan guarantee is USD 25 million and the maximum grant funding is $25 \%$ of project costs. At least $20 \%$ of the grant funds awarded must be for grants of USD 20000 or less. (USDOE/AFDC, 2013).

The US Department of Energy lists incentives in half the states that support investment in biofuel-distribution infrastructure. These range from the Arizona Biofuel Conversion Program, which distributes grants worth up to USD 75000 to cover the incremental cost of projects that result in new or converted biofuel storage and dispensing equipment, to Wisconsin's Renewable Fuel Infrastructure Tax Credit, which provides an income-tax credit that covers $25 \%$ of the cost of installing or retrofitting fuelling stations that dispense motor vehicle fuel blends of at least $85 \%$ ethanol or at least $20 \%$ biodiesel fuel, or that mix fuels from separate storage tanks and allow the user to select the percentage of renewable fuel (USDOE/AFDC, 2013).

Other countries and sub-national governments have also helped finance infrastructure for storing and distributing biofuels. The Canadian Province of Ontario's Independent Gasoline Blender's Transition Fund, for example, has allocated CAD 16 million to help independent retailers install equipment for dispensing ethanol blends. Thailand provides gasoline stations that dispense E20 with an extra THB 0.5 (USD 0.02) per litre marketing margin on sales of the fuel; it provides a THB 0.3 (USD 0.01) per litre subsidy on sales of B5. In Brazil, all retail filling stations are required to sell both E25 and pure ethanol (E100) (Blandford et al., 2010). In addition, the federal government, through the Brazilian Development Bank (BNDES), has for many years offered preferential credit to support ethanol storage. However, according to 
Baross (2012), "due to the strict credit requirements to access the money, [the] funds have been virtually untouched."

\section{Import barriers}

Although the focus of this study is on domestic incentive measures, to understand the effects of such measures, they cannot be looked at in isolation. Often, incentives interact with trade barriers in ways that substantially alter the effects that the incentives would have in the absence of such barriers - for example, turning a policy that might otherwise increase imports of a biofuel into one that favours domestic suppliers. Among most OECD and major non-OECD economies, applied import tariffs on ethanol on the one hand, and substitutes for middle distillates (biodiesel and bio-jet) on the other, differ considerably (Table A.10). Import duties on fuel ethanol (ethyl alcohol) are often expressed as specific-rate tariffs, and on an ad valorem-equivalent basis in many countries - including major OECD countries - these exceed 20\%. On imports of undenatured ethanol, the Russian Federation charges a 100\% tariff, and India charges a 150\% tariff. By contrast, import duties on biodiesel are generally less than 10\%, except in Argentina and Brazil, which charge 14\%. The gap between bound and applied tariffs is wide.

In a few countries, exports of biofuel feedstocks, and sometimes even exports of biofuels themselves, are subject to export taxes. Prior to August 2012, for example, Argentina applied a $17.8 \%$ percent lower export tax on exports of biodiesel than on soybean oil (after accounting for a small rebate on the biodiesel tax). The recent increase in the tax to a uniform $32 \%$ rate will mean that all sub-products of soybeans will face the same tax (Markley, 2012). Indonesia also applies an export tax on palm-oil and palm-oil-based products, including biodiesel. Its export tax on palm oil is $1.5 \%$ for every USD 50 above the price of USD 750 per metric tonne, and in 2012 the export tax on biodiesel and other refined palm-oil products was reduced from 25\% to $10 \%$ (Yulisman, 2013).

Table A.10. Average import tariffs of major importers on liquid biofuels, 2013

\begin{tabular}{|c|c|c|c|c|c|c|}
\hline \multirow{3}{*}{ Country } & \multicolumn{4}{|c|}{ Ethanol } & \multirow{2}{*}{\multicolumn{2}{|c|}{$\frac{\text { Biodiesel }^{1} \text { and bio-jet }}{\text { (HS 3826) }}$}} \\
\hline & \multicolumn{2}{|c|}{ Undenatured (HS 2207.10) } & \multicolumn{2}{|c|}{ Denatured (HS 2207.20) } & & \\
\hline & MFN Applied & Bound & MFN Applied & Bound & MFN Applied & Bound2 \\
\hline Australia & $5 \%+$ AUD 74.27/litre & $10 \%$ & $\begin{array}{c}5 \%+\text { AUD } \\
0.38143 / \text { litre }\end{array}$ & $8 \%$ & $\begin{array}{c}\text { AUD 0.38143/ } \\
\text { litre }^{3}\end{array}$ & $10 \%$ \\
\hline Canada & $\begin{array}{l}\text { CAD 0.0492/ litre of } \\
\text { absolute alcohol }\end{array}$ & $\begin{array}{c}\text { CAD } 0.0492 / \text { litre } \\
\text { of absolute } \\
\text { alcohol }\end{array}$ & $\begin{array}{l}\text { CAD 0.0492/ litre of } \\
\text { absolute alcohol }\end{array}$ & $\begin{array}{l}\text { CAD 0.0492/ litre of } \\
\text { absolute alcohol }\end{array}$ & $0 \%$ & $6.5 \%$ \\
\hline Chile & $6 \%$ & $25 \%$ & $6 \%$ & $25 \%$ & $6 \%$ & $25 \%$ \\
\hline EU4 & EUR 19.2/hl & EUR 19.2/hl & EUR 10.20/hl & EUR 10.20/hl & $6.5 \%$ & $6.5 \%$ \\
\hline Iceland & $0 \%$ & $7 \%$ & $0 \%$ & $7 \%$ & $0 \%$ & $10 \%$ \\
\hline Israel & $8 \%$ & $148 \%$ & $0 \%$ & $148 \%$ & $0 \%$ & $12 \%$ \\
\hline Japan & JPY 38.1/litre & $\begin{array}{c}27.2 \%+ \\
\text { JPY } 38.1 / \text { litre }\end{array}$ & JPY 38.1/litre & $\begin{array}{c}27.2 \%+ \\
\text { JPY } 38.1 / \text { litre }\end{array}$ & $3.9 \%$ & $0 \%$ \\
\hline Korea & $30 \%$ & $90 \%$ & $8 \%$ & $8 \%$ & $6.5 \%$ & $6.5 \%$ \\
\hline Mexico & $10 \%+$ USD $0.36 / \mathrm{kg}$ & $45 \%$ & $10 \%+$ USD $0.36 / \mathrm{kg}$ & $45 \%$ & $6 \%$ & $35 \%$ \\
\hline New Zealand & 0\% - NZD 49.55/litre & $1.4-3.7 \%$ & $0 \%$ - NZD 49.55/ litre & $2.8-3.7 \%$ & $0 \%$ & $0 \%$ \\
\hline Norway & $0 \%$ & $0 \%$ & $0 \%$ & $0 \%$ & $0 \%$ & $0 \%$ \\
\hline Switzerland & CHF $35 / 100$ gross $\mathrm{kg}$ & $\begin{array}{l}\text { CHF } 35 / 100 \\
\text { gross kg }\end{array}$ & $\begin{array}{c}\text { CHF 0.7/100 gross } \\
\mathrm{kg}\end{array}$ & $\begin{array}{c}\text { CHF 0.7/100 gross } \\
\mathrm{kg}\end{array}$ & $0 \%$ & Un-bound \\
\hline Turkey & EUR 19.2/hl & $102 \%$ & EUR 10.2/hl & $102 \%$ & $6.5 \%$ & $15 \%$ \\
\hline
\end{tabular}


DOMESTIC INCENTIVE MEASURES FOR RENEWABLE ENERGY WITH POSSIBLE TRADE IMPLICATIONS

Table A.10. Average import tariffs of major importers on liquid biofuels, 2013 (cont.)

\begin{tabular}{|c|c|c|c|c|c|c|}
\hline \multirow{3}{*}{ Country } & \multicolumn{4}{|c|}{ Ethanol } & \multirow{2}{*}{\multicolumn{2}{|c|}{$\begin{array}{c}{\text { Biodiesel }{ }^{1} \text { and bio-jet }}^{(\mathrm{HS} \mathrm{3826})} \\
\end{array}$}} \\
\hline & \multicolumn{2}{|c|}{ Undenatured (HS 2207.10) } & \multicolumn{2}{|c|}{ Denatured (HS 2207.20) } & & \\
\hline & MFN Applied & Bound & MFN Applied & Bound & MFN Applied & Bound $^{2}$ \\
\hline United States & $2.5 \%$ & $2.5 \%$ & $1.9 \%$ & $1.9 \%$ & $4.6-6.5 \%$ & $6.5 \%$ \\
\hline Argentina & $20 \%$ & $35 \%$ & $20 \%$ & $35 \%$ & $14 \%$ & $20 \%$ \\
\hline Brazil & $20 \%$ & $35 \%$ & $20 \%$ & $35 \%$ & $14 \%$ & $20 \%$ \\
\hline China & $40 \%$ & $40 \%$ & $30 \%$ & $30 \%$ & $6.5 \%$ & $6.5 \%$ \\
\hline Egypt & $2-10 \%$ & $80 \%$ & $10 \%$ & $80 \%$ & $5 \%$ & $10 \%$ \\
\hline India & $150 \%$ & $150 \%$ & $7.5 \%$ & $150 \%$ & $10 \%$ & $40 \%$ \\
\hline Indonesia & $30 \%$ & $70 \%$ & $30 \%$ & $70 \%$ & $5 \%$ & $40 \%$ \\
\hline Malaysia & MYR 60/litre & MYR 112/litre & MYR 3-3.5/litre & MYR 1/litre & $0 \%$ & $5 \%$ \\
\hline Russia & $\begin{array}{c}100 \%, \\
\text { and no less than } \\
\text { EUR 2/litre }\end{array}$ & $\begin{array}{l}100 \% \text {, and no } \\
\text { less than } \\
\text { EUR 2/litre }\end{array}$ & $\begin{array}{c}100 \% \text {, and no less } \\
\text { than } \\
\text { EUR } 2 / \text { litre }\end{array}$ & $\begin{array}{c}100 \% \text {, and no } \\
\text { less than } \\
\text { EUR 2/litre }\end{array}$ & $5 \%$ & $5 \%$ \\
\hline South Africa & ZAL 3.17/litre & $597 \%$ & ZAL 3.17/litre & $597 \%$ & ZAL 1.83/litre & $15 \%$ \\
\hline
\end{tabular}

1. With the implementation of HS 2012, a new, additional code -2710.20 - is being used for preparations (blends) containing up to $30 \%$ biodiesel.

2. Refers to bindings under HS 3824.90, the code in use prior to HS 2012.

3. In addition, on 18 April 2011, Australia began imposing a 40\% anti-dumping duty on imports of US biodiesel.

4. In addition, on 22 February 2013, the European Union began applying a EUR 62.9 per metric ton duty on all imports of ethanol from the United States that are aimed at the fuel market; this duty will remain in place until February 2018. Since 2009, the European Union has also been imposing anti-dumping and countervailing (anti-subsidy) duties on imports from the US of biodiesel; the rates vary according to company.

Data sources: MFN Applied tariffs: Market Access Database (http://madb.europa.eu/mkaccdb2/indexPubli.htm); Bound tariffs: WTO (https://tariffanalysis.wto.org/).

\section{Technology-push policies}

Government support for research, development and demonstration (RD\&D)

Most biofuel-producing countries have established government-funded programmes to support research and innovation, development and demonstration in respect of different stages in the biofuel value chain. Because of the many specialisations involved, from agronomy to material science, and the different government agencies with an interest in biofuels (agriculture, energy, transport, environment), identifying all the programmes directly and indirectly benefiting the industry is beyond the scope of this study. What is clear is that an increasing proportion of $\mathrm{R} \& \mathrm{D}$ funds to the sector are being channelled towards secondgeneration biofuels, particularly cellulosic ethanol and biomass-derived alternatives to petroleum diesel and jet kerosene. Notable examples include:

- AUD 2.8 million for the Second Generation Biofuels Research and Development Program in Australia.

- The European Union's $7^{\text {th }}$ Framework Programme (FP7) for research and technological development, the European Union's primary instrument for funding research and demonstration activities over the period of 2007 to 2013, which has prioritised largescale demonstration projects with a particular emphasis on biofuel production from ligno-cellulosic biomass. The ten large-scale demonstration projects that have received funding so far have involved large industrial consortia and have targeted four value chains: synthetic biofuels, lignocellulosic ethanol, pyrolysis, and biofuels from algae.

- Separately, the NER300 programme, launched in November 2010, has been supporting demonstration projects for carbon capture and storage (CCS) and innovative technologies to tap renewable-energy sources. Funding for the programme comes from 
the sale of 300 million emission allowances. The number of projects eligible for cofunding between the European Union and its Member States in the area of bio-energy is nine. Of the eight sub-categories under bio-energy, seven involve the use of lignocellulosic raw material, and one covers projects that involve algae or microorganisms in the production of biofuels or bioliquids via biological or chemical processes. NER300 funds up to $50 \%$ of the relevant costs of the projects. ${ }^{78}$

- The European Industrial Bioenergy Initiative (EIBI), one of the industrial initiatives launched under the European Strategic Energy Technology Plan (SET-Plan), was launched in 2009 to assist the development of large-scale, advanced bioenergy plants by 2020. The initiative, which will ultimately fund 15 to 20 demonstration plants and reference-plants, has a budget of EUR 6-8 billion to be spent over ten years. Its aim is to reduce production costs so that advanced biofuels (i.e. sustainably produced biofuels with a broader material base or better end-product properties than biofuels currently on the market) become competitive with fossil fuels under prevailing economic and regulatory market conditions. ${ }^{79}$ And in another related initiative, in January 2013 a consortium of eight European countries (Denmark, Finland, Germany, Portugal, Spain, Sweden, Switzerland, and the United Kingdom) launched a new activity called "Bioenergy Sustaining the Future" (BESTF). This activity will provide funding to collaborative bio-energy projects (including solid and gaseous fuels, besides liquid fuels) that demonstrate at least one innovative step and that result in demonstration at a precommercial stage. ${ }^{80}$

- The US Government has long supported research into biofuels, especially advanced biofuels. In August 2011, the US Department of Agriculture (USDA), the US Department of Energy (DOE) and the US Navy announced that they would jointly invest up to USD 510 million during the next three years, in partnership with the private sector (which will have to at least match government spending), to produce advanced aviation and marine biofuels to power military and commercial transportation. Each department contributed equally to the USD 510 million in funding, which involved re-directing funds from already authorised programmes. The Navy will provide a market for the fuel, the US DOE is taking the lead on technology, and the USDA is taking the lead on addressing feedstocks.

\section{Government support for investment in productive capacity}

Biofuel production facilities throughout the world have benefited from a multitude of government-support policies, including grants, concessional credit, conditional loans, and loan guarantees. Whereas support at the national level has tended to focus on biofuelmanufacturing plants that incorporate innovative designs or technologies, this has been less the case at the sub-national level.

In-depth studies of the biofuels sectors of Australia, Canada, China, the European Union, Malaysia, Indonesia, Switzerland and the United States carried out by the Global Subsidies Initiative (GSI) between 2006 and 2009 documented hundreds of programmes then providing assistance to developers of ethanol and biodiesel manufacturing plants.

Canada's main federal programme for supporting investment in biofuel manufacturing is the ecoAgriculture Biofuels Capital Initiative (ecoABC), which provides repayable

\footnotetext{
78. http://ec.europa.eu/clima/funding/ner300/index_en.htm.

79. www.biofuelstp.eu/eibi.html.

80. www.eranetbestf.net/wp-content/uploads/2012/11/BESTF_Call_text_final.pdf.
} 
contributions of up to CAD 25 million per project for the construction or expansion of transportation biofuel production facilities. Funding is provided for projects that use agricultural feedstocks to produce biofuels and that have new agricultural producer equity investments in the projects equal to, at minimum, $5 \%$ of the total eligible project costs. The deadline for the construction or expansion of biofuels facilities funded by ecoABC was recently extended until 30 September 2012. As of October 2011, some 23\% of the CAD 186 million available under ecoABC had been allocated. In addition, the NextGen Biofuels Fund has supported the establishment of large demonstration-scale facilities for the production of next-generation renewable fuels (e.g. ellulosic ethanol). The federal government's budget of 2007 provided Sustainable Development Technology with CAD 500 million to create the Fund.

$E U$ member states are allowed, and the RES directive encourages such support, to promote "better performing biofuels" by favouring them in national support systems (and by double-counting them towards the renewable-energy-in-transport target). Through the end of 2010, Denmark had spent DKK 200 million (EUR 25 million) supporting six advancedbiofuel projects, mainly for the production of cellulosic ethanol. Finland's BioRefine programme is promoting the development of second-generation production technologies for advanced biofuels for transport, and in 2009, granted EUR 37 million for business development and EUR 19 million for research in this area. Additionally, it manages a programme for pilot and demonstration projects for these new technologies. In Germany, the focus of government support has been mainly on the provision and pre-treatment of feedstock for biomass-to-liquids (BTL) plants. The Netherlands has dedicated EUR 60 million to fund both investments and operating costs of facilities that produce innovative biofuels that yield significant reductions in $\mathrm{CO}_{2}$ emissions.

At the federal level, the United States currently supports the construction of biofuel manufacturing capacity through two major programmes. The Biorefinery Assistance Program, administered by the USDA, provides loan guarantees (of up to USD 250 million) for the development, construction, and retrofitting of commercial-scale biorefineries that produce advanced biofuels (i.e. fuel derived from renewable biomass other than starch from maize). The US Department of Energy (DOE) issues loan guarantees through its Loan Guarantee Program for up to $100 \%$ of the amount of the loan for eligible projects, including for biofuels, that reduce air pollution and greenhouse gases and support the early commercial adoption of advanced technologies. The USDOE describes its Loan Programs Office as "one of the largest and most active project-finance operations in the world". Since 2009 it has supported a diverse portfolio of more nearly 40 projects, and in 2011, it signed two agreements relating to commercial-scale cellulosic ethanol plants; the total value of the associated loan guarantees was USD 240 million.

Numerous US states also provide investment incentives for biofuel manufacturing plants, as do local governments through their local economic-development programmes. The web site Good Jobs First (www.goodjobsfirst.org/subsidy-tracker) shows that investment incentives provided by states since 2005 have been worth at least USD 200 million to biofuel producers. The State of Louisiana offers a corporate or income "Green Jobs" tax credit - for $10-25 \%$ of the project's investment costs, up to USD 1 million per project - for statecertified "green" capital infrastructure projects. According to the USDOE/AFDC (2013), "[t]he portion of the base investment expended on payroll for Louisiana residents employed in connection with the construction of the project may be eligible for an additional $10 \%$ tax credit on the payroll; restrictions may apply".

More than ten of Argentina's 23 provinces have adhered to the national Biofuels Law (Law 26,093), and some provide additional tax advantages for investment and construction of biorefineries in their territories (Joseph, 2012). For example, since 2007, the Province of Cordoba has offered biofuel projects engaged in the production, process and consumption of 
biofuel for third parties numerous tax exemptions. These include exclusion for 15 years from the tax on gross income; the production, industrialisation and storage tax; and taxes on the sealing of acts, agreements and transactions which have as subject matter a biofuel product. The projects can also benefit from loans supported by the Official Bank at a subsidised rate (Ministry of Production and Work of Cordoba Province, 2008).

\section{Government support for intermediate inputs to production}

The main intermediate inputs used in the production of biofuels are the biomass feedstock, which for ethanol made through first-generation fermentation processes ranges from raw sugar (derived from sugarcane or sugarbeets) or molasses, to starch from grains such as wheat, maize and sorghum. For biodiesel and bio-jet, the feedstocks are generally either plant oils, used cooking oils, or fatty animal wastes, such as tallow. ${ }^{81}$ For secondgeneration biofuel production processes, biomass containing mainly complex carbon-based molecules, such as grasses and woody plant material, are expected to become important feedstocks.

Direct and indirect support for crops used in biofuel production has been around for almost two decades. In 1993, for example, the $E U$ provided area-based payments for crops grown on set-aside land for industrial and energy purposes; this programme was formally ended in 2010. Brazil has, at times since it began its National Alcohol Programme (PróÁlcool) in the 1970s, offered low-interest loans for agro-industrial ethanol firms. Following a supply shortage in 2010 and 2011, which saw domestic production of ethanol fall by 19\%, in January 2012, Brazil's Development Bank (BNDES) introduced a new credit line (available through the end of 2012), called Prorenova, of BRL 4 billion (USD 2 billion) to finance the renewal or expansion of more than one million hectares of sugarcane fields. The expectation was that, with the increased availability of raw materials this line of credit would engender, Brazil's production of ethanol would increase by between 2 and 4 billion litres from 2013 until 2014, representing growth of over $10 \%$ compared with the previous crop. ${ }^{82}$ Uptake by the industry has been limited, however, due to the strict requirements imposed on applicants for the credit (Barros, 2012).

Today, the main programme for supporting the production of feedstock for biofuels in the United States is the USDA's Biomass Crop Assistance Program (BCAP). Under this programme, the US federal government underwrites up to $75 \%$ of the cost a farmer incurs in establishing a perennial crop. Eligible costs do not include the acquisition of land or equipment, and establishment payments are available only for perennial crops. Producers of annual crops, as well as of perennial crops, are eligible, however, for annual payments, which can be made for up to five years for herbaceous biomass and up to 15 years for woody biomass and decline over time. ${ }^{83}$ In addition, the programme provides matching payments (up

81. Water, and fuels for providing process heat in the fermentation and distillation processes are also important inputs to the manufacturing of ethanol; methanol and sodium hydroxide are important for the manufacturing of biodiesel; and hydrogen is used in the manufacturing of certain types of bio-jet. But identifying government support for these inputs was beyond the scope of this study.

82.

www.bndes.gov.br/SiteBNDES/bndes/bndes_en/Institucional/Press/Noticias/2012/2012011 1_BNDES_Prorenova.html.

83. www.fsa.usda.gov/Internet/FSA_File/bcap_update_may2011.pdf. 
to a limit of USD 45 per dry short ton (USD 41 per dry tonne)) for up to two years on sales of their crops to the biofuel refinery. In the round of grants announced in August 2011: ${ }^{84}$

- Two of the new BCAP project areas (including parts of California, Montana, Washington and Oregon), aiming at an enrolment of approximately 20000 hectares, will grow the oilseed, Camelina sativa (false flax), to provide feedstock for producing bio-jet fuel.

- Another BCAP project area (covering up to 7000 acres in Oregon), aims to enrol land for growing hybrid poplar for conversion into cellulosic biofuels.

- A fourth BCAP project (20 000 acres in Kansas and Oklahoma) has been designated to grow switchgrass for conversion into cellulosic biofuels. The project area surrounds a future biomass conversion facility in Hugoton, Kansas.

\section{Government support for manufacturing}

The trend in recent years in several OECD countries has been to replace excise-tax credits (which, in most cases, have not discriminated by country of origin) with production-tax credits (available only to domestic producers).

The European Union for many years (until 31 July 2012) subsidised small amounts of fuel-ethanol production through the crisis-distillation mechanism for wine. This mechanism paid companies to distil alcohol out of low-quality wine, provided that the alcohol must then be sold for purposes other than potable use. In 2006, some 680 million litres of wine (equivalent to around 95 million litres of pure ethanol) were removed through the crisisdistillation mechanism (Kutas et al., 2007), at a total cost to the EU of EUR 445 million (USD 591 million), or almost EUR 2 per litre of pure ethanol distilled (OECD PSE/CSE database, 2011). Around half of these quantities were subsequently sold as fuel ethanol. Since then, support has been rapidly phased out, and totaled around EUR 100000 in 2011. Since 1 August 2012, EU Member States may grant national aid to wine producers for the voluntary or mandatory distillation of wine in justified cases of crisis. Other direct production subsidies to manufacturers of biofuels are granted mainly by the newer of the EU's Member States. This support has taken various forms. The Czech Republic applies subsidies based on current volume of output, whereas Latvia bases its subsidies on historical levels of output.

Elsewhere, producer payments are the main instrument used to support ethanol and biodiesel production. In April 2008, Canada's federal government created the CAD 1.5 billion (USD 1.4 billion), nine-years ecoENERGY for Biofuels Program. The programme provides an operating incentive - based on production and sales levels - for renewable alternatives to gasoline and diesel produced in Canada (Department of Finance Canada, 2007). Incentive rates started at CAD 0.10 per litre for renewable alternatives to gasoline and up to CAD 0.26 per litre for renewable alternatives to diesel and decline thereafter. Initially, the incentive rates were variable, set according to a formula that took into account market conditions; in December 2009, they were changed to fixed declining incentive rates. ${ }^{85}$ Support under the programme to individual companies is capped.

Five Canadian provinces (Alberta, Saskatchewan, Manitoba, Ontario, and Quebec) also provide production incentives in the form of direct payments or income-tax credits. All five support the production of ethanol; Alberta, Saskatchewan, and Manitoba also support the

84

www.fsa.usda.gov/FSA/newsReleases?area=newsroom\&subject=landing\&topic=ner\&newstype $=$ newsrel\&type $=$ detail\&item=nr_20110726_rel_0320.html

85. www.nrcan.gc.ca/audit/reports/2011-03/ecoenergy-biofuels/1187\#a2d. 
production of biodiesel. Alberta's programme in addition covers biologically derived oils and biogas. Ontario's and Quebec's incentives on first-generation ethanol are calculated according to formulas that take into consideration relative prices between crude oil and ethanol. Quebec's incentive for cellulosic ethanol is similarly calculated but based on the US market price of ethanol rather than on the price of crude oil. Alberta's and Manitoba's are straightforward per-litre payments. Alberta caps the amount paid per plant (and provides a 55\% higher per-litre payment for plants with an annual capacity less than 150 million litres). Manitoba applies only a total cap, proportional to the province-wide mandated ethanol content in each year. To be eligible for the payment, the ethanol has to be produced and sold in Manitoba (Gray, 2012).

In the United States, three production-related incentives have been offered for biofuels by the federal government. The "Small Ethanol Producer Tax Credit" and the "Small AgriBiodiesel Producer Tax Credit", each worth USD 0.10 per gallon (USD 0.026 per litre), expired at the end of 2011. These credits were granted on the first 15 million gallons (56 million litres) of liquid biofuels produced by US plants with an annual capacity of less than 60 million gallons (225 million litres). Bills were introduced in Congress in 2012 to reinstate these tax credits but failed to attract sufficient votes. The main remaining support policy is the "Second Generation Biofuel Producer Tax Credit", which provides US producers of biofuels made from qualifying feedstocks (any lignocellulosic or hemicellulosic matter that is available on a renewable basis, or any cultivated algae, cyanobacteria, or lemna ${ }^{86}$ ) with a tax incentive of USD 1.01 per gallon of cellulosic biofuel produced and sold. Under current law, only qualified fuel produced in the United States between 1 January 2009 and 31 December 2013, for use in the United States, is eligible.

Separately, through the Bioenergy Program for Advanced Biofuels, eligible producers of advanced biofuels, or fuels derived from renewable biomass other than starch derived from maize kernels, may receive payments to support expanded production. Payment amounts depend on the quantity and duration of production by the eligible producer; the net nonrenewable energy content of the advanced biofuel, if sufficient data are available; the number of producers participating in the programme; and the amount of funds available. No more than $5 \%$ of the funds can be made available to eligible producers with an annual refining capacity of more than 150 million gallons (568 million litres) of advanced biofuel. Section 9005 of the 2008 Farm Bill authorised expenditure of USD 85 million in FY 2011, and USD 105 million in FY 2012, as well as an additional authorisation of discretionary funds in the amount of USD 25 million per year (Krome et al., 2009).

At least 12 US states provide their own volumetric subsidies to support in-state production of ethanol or biodiesel, many at rates equivalent to USD 0.20 per gallon (USD 0.053 per litre) of pure biofuel (Table A.11). In the case of cellulosic biofuels, when combined with the tax credits already provided by the federal government, the aid intensity can be equivalent to almost $90 \%$ of the pre-tax retail value of the fuel. Many of the state-level production subsidies are provided up to an annual limit. In the State of Montana, the production tax incentive of USD 0.20 per gallon (USD 0.053 per litre) is available only for ethanol produced solely from Montana agricultural products, or ethanol produced from nonMontana agricultural products when Montana products are unavailable. As described by the US Department of Energy: ${ }^{87}$

86. Lemna refers to a genus of minute aquatic herbs (e.g. duckweed) that float on or below the surface of fresh water and which consist of a leaf-like frond or plant body and a single root.

87. See www.afdc.energy.gov/afdc/laws/laws/MT\#State Incentives. 
If the producer uses non-Montana based agricultural products, the amount of the tax incentive for each gallon is reduced proportionately, based on the percentage of non-Montana based agricultural or wood products used in production. An ethanol producer is not eligible to receive the tax incentive unless the entity uses at least $20 \%$ Montana products to produce the ethanol in the first year of production and $25 \%$ Montana products in the second year, and the producer must increase the amount of Montana product used each year thereafter by $10 \%$.

Missouri makes access to its Qualified Producer Incentive Fund contingent not only on domestic content, ${ }^{88}$ but also on ownership: at least $51 \%$ of the production facility must be owned by agricultural producers who are residents of the state and who are actively engaged in agricultural production for commercial purposes.

Table A.11. Production-related incentives for ethanol and biodiesel in OECD countries as of early 2013

\begin{tabular}{|c|c|c|c|}
\hline Country & Ethanol & Biodiesel & Comment \\
\hline $\begin{array}{l}\text { Canada } \\
\text { (Federal) }\end{array}$ & CAD 0.06/litre & CAD 0.14/litre & $\begin{array}{l}\text { Incentive rates decline over the life of the programme, } \\
\text { from CAD } 0.10 / \text { litre in } 2008-09 \text { to CAD } 0.03 \text { /litre in } \\
2016-17 \text { (for renewable alternatives to gasoline) and } \\
\text { CAD } 0.26 \text { in } 2008-09 \text { to CAD } 0.04 \text { in } 2016-17 \text { (for } \\
\text { renewable alternatives to diesel) }\end{array}$ \\
\hline Alberta & $\begin{array}{l}\text { CAD 0.06-0.10/litre } \\
\left(1^{\text {st }} \text {-gen }\right) \\
\text { CAD 0.09-0.14/litre } \\
\left(2^{\text {nd }} \text {-gen }\right)\end{array}$ & CAD 0.09-0.13/litre & $\begin{array}{l}\text { Higher payment for plants with capacity of less than } \\
150 \text { million litres/year. Caps of CAD 18-25.5 million per } \\
\text { facility per programme year. }\end{array}$ \\
\hline \multirow[t]{2}{*}{ Saskatchewan } & CAD 0.10/litre & CAD 0.13/litre & $\begin{array}{l}\text { Ethanol Fuel Grant: paid to eligible distributors who } \\
\text { blend Saskatchewan produced ethanol within } \\
\text { Saskatchewan for sale in Saskatchewan. }\end{array}$ \\
\hline & & & $\begin{array}{l}\text { Renewable Diesel Program: pays qualified producers in } \\
\text { Saskatchewan. The incentive program terminates } \\
\text { 31.03.16. }\end{array}$ \\
\hline Manitoba & $\begin{array}{l}\text { CAD 0.10/litre from } \\
2013 \text { through } 2015\end{array}$ & CAD 0.14/litre & $\begin{array}{l}\text { Qualifying fuel has to be produced and sold in } \\
\text { Manitoba. The incentives are subject to annual caps. }\end{array}$ \\
\hline Ontario & $\begin{array}{c}\text { Up to } \\
\text { CAD } 0.11 / \text { /itre }\end{array}$ & - & $\begin{array}{l}\text { CAD } 60.5 \text { million per year from } 2007-17 \text { for operating } \\
\text { assistance, adjusted according a formula that takes into } \\
\text { account market conditions. }\end{array}$ \\
\hline Quebec & $\begin{array}{l}\text { up to } \\
\text { CAD } 0.185 / \text { litre }\left(1^{\text {st }}-\right. \\
\text { gen }) \text { and up to } \\
\text { CAD } 0.15\left(2^{\text {nd }} \text {-gen }\right)\end{array}$ & - & $\begin{array}{l}\text { Production tax credit granted to producers of ethanol } \\
\text { from renewable material that sell the ethanol for use in } \\
\text { Québec. For first-generation ethanol, no credit is given } \\
\text { for a month during which the monthly average price of } \\
\text { crude oil equals or exceeds USD } 65 \text { per barrel or the } \\
\text { total cumulative production of ethanol exceeds } \\
1.2 \text { billion litres. For second-generation ethanol, the } \\
\text { ethanol must be produced from industrial, agricultural or } \\
\text { household residual material using a thermo-chemical } \\
\text { process. No credit is given for a month during which the } \\
\text { monthly average price of ethanol equals or exceeds } \\
\text { USD 3.13333/gal. }\end{array}$ \\
\hline
\end{tabular}

88. See Chapter 142 of the Motor Fuel Tax, Section 142.028 (www.moga.mo.gov/statutes/C100199/1420000028.HTM). 
Table A.11. Production-related incentives for ethanol and biodiesel in OECD countries as of early 2013 (continued)

\begin{tabular}{|c|c|c|c|}
\hline Country & Ethanol & Biodiesel & Comment \\
\hline \multicolumn{4}{|l|}{ United States } \\
\hline \multicolumn{4}{|l|}{ Federal } \\
\hline $\begin{array}{l}\text { Producers } \\
\text { using } \\
\text { cellulosic } \\
\text { feedstock }\end{array}$ & $\begin{array}{c}\text { USD } 0.267 \\
\text { (USD 1.01/gal) }\end{array}$ & - & \\
\hline \multicolumn{4}{|l|}{ State } \\
\hline Arkansas & $\begin{array}{c}\text { USD } 0.0528 \\
\text { (USD 0.20/gal) }\end{array}$ & $\begin{array}{c}\text { USD } 0.0528 \\
\text { (USD 0.20/gal) }\end{array}$ & Not to exceed USD 2 million per facility. \\
\hline Hawaii & $\begin{array}{l}\text { USD } 0.079 \\
\text { (USD 0.30/gal) }\end{array}$ & - & $\begin{array}{l}\text { Income-tax credit, subject to facility size and } \\
\text { other limits. See } \\
\text { http://www.capitol.hawaii.gov/hrscurrent/Vol0 } \\
\text { 4_Ch0201-0257/HRS0235/HRS_0235- } \\
\text { 0110_0003.htm. }\end{array}$ \\
\hline Indiana & $\begin{array}{c}\text { USD } 0.033 \\
\text { (USD } 0.125 / \mathrm{gal})\end{array}$ & $\begin{array}{l}\text { USD } 0.26 \\
\text { (USD 1.00/gal) }\end{array}$ & $\begin{array}{l}\text { Subject to volume and annual per recipient } \\
\text { limits. As of April 2012, no funds had been } \\
\text { appropriated for these incentives. }\end{array}$ \\
\hline Kansas & $\begin{array}{l}\text { USD } 0.00925 \\
\text { (USD 0.035/gal) }\end{array}$ & $\begin{array}{l}\text { USD } 0.079 \\
\text { (USD 0.30/gal) }\end{array}$ & $\begin{array}{l}\text { Ethanol production incentives (one for grain } \\
\text { alcohol, another for cellulosic alcohol) are } \\
\text { only on incremental sales above a base, and } \\
\text { for an annual maximum of } 15 \text { million gallons. } \\
\text { Grain-alcohol producers must have started } \\
\text { producing before } 1 \text { July } 2012 \text {. Ethanol } \\
\text { incentive expires on } 1 \text { July } 2018 \text {, biodiesel } \\
\text { incentive on } 1 \text { July } 2016 \text {. }\end{array}$ \\
\hline Maine & $\begin{array}{l}\text { USD } 0.0132 \\
\text { (USD } 0.05 / \mathrm{gal})\end{array}$ & $\begin{array}{l}\text { USD } 0.0132 \\
\text { (USD } 0.05 / \text { gal) }\end{array}$ & - \\
\hline Maryland & $\begin{array}{l}\text { USD } 0.0132-0.0528 \\
\text { (USD } 0.05-0.20 / \text { gal) } \\
\text { on up to } 15 \text { million } \\
\text { gallons per year }\end{array}$ & $\begin{array}{l}\text { USD } 0.0132-0.0528 \\
\text { (USD } 0.05-0.20 / \text { gal) on } \\
\text { up to } 5 \text { million gallons } \\
\text { per year }\end{array}$ & $\begin{array}{l}\text { Highest ethanol payment rate if small grains } \\
\text { used as feedstock. Highest biodiesel payment } \\
\text { rate if soybean oil used as feedstock. } \\
\text { Payments are made for ethanol or biodiesel } \\
\text { produced between } 31.12 .2007 \text { and } \\
31.12 .2017 \text {. }\end{array}$ \\
\hline Missouri & $\begin{array}{l}\text { USD } 0.053 \text { (USD } \\
0.20 / \text { gal) for the first } \\
12.5 \text { million gallons } \\
\text { and USD } 0.013 \\
\text { (USD } 0.05 / \text { gal) for } \\
\text { the next } 12.5 \text { million } \\
\text { gallons each year }\end{array}$ & - & $\begin{array}{l}\text { Contingent on the use of Missouri agricultural } \\
\text { products or qualified biomass each fiscal } \\
\text { year, up to USD } 7.5 \text { million cumulative per } \\
\text { producer. Expires end-2015. }\end{array}$ \\
\hline Montana & $\begin{array}{l}\text { up to USD } 0.0528 \\
\text { (USD 0.20/gal) }\end{array}$ & $\begin{array}{l}\text { USD } 0.0753 \\
\text { (USD 0.285/gal) }\end{array}$ & $\begin{array}{l}\text { Ethanol Production Incentive: Conditional on } \\
\text { use of "Montana agricultural products, } \\
\text { including Montana wood or wood products". } \\
\text { Biodiesel Tax Exemption: available only for } \\
\text { biodiesel made from waste vegetable oil. }\end{array}$ \\
\hline
\end{tabular}




\begin{tabular}{|c|c|c|c|}
\hline Country & Ethanol & Biodiesel & Comment \\
\hline $\begin{array}{l}\text { South } \\
\text { Carolina }\end{array}$ & $\begin{array}{l}\text { USD } 0.0528-0.079 \\
\text { (USD } 0.20-0.30 / \text { gal) }\end{array}$ & $\begin{array}{l}\text { USD } 0.0528-0.079 \\
\text { (USD } 0.20-0.30 / \text { gal) }\end{array}$ & $\begin{array}{l}\text { Higher rate for producers using feedstocks } \\
\text { other than corn or soy oil. An eligible } \\
\text { production facility must be operating at a } \\
\text { production rate of at least } 25 \% \text { of its name- } \\
\text { plate design capacity and must maintain that } \\
\text { production rate for at least six months, before } \\
\text { denaturing, on or before } 31 \text { December } 2011 \text {. } \\
\text { The credit is allowed for up to } 60 \text { months } \\
\text { beginning with the first month for which the } \\
\text { facility is eligible to receive the credit and } \\
\text { ending before } 31 \text { December } 2016 \text {. Beginning } \\
1 \text { January } 2017 \text {, the credit to USD } 0.075 / g a l \\
\text { of fuel produced. }\end{array}$ \\
\hline South Dakota & $\begin{array}{l}\text { USD } 0.0528 \\
\text { (USD 0.20/gal) }\end{array}$ & - & $\begin{array}{l}\text { Paid to producers that were producing } \\
\text { ethanol on or before } 31 \text { December } 2006 \text {. } \\
\text { Annual production incentives paid to one } \\
\text { facility may not exceed USD } 1 \text { million. The } \\
\text { ethanol must be distilled from cereal grains. } \\
\text { Cumulative annual production incentives paid } \\
\text { out to all facilities may not exceed USD } 4 \text { mil- } \\
\text { lion in } 2013 \text {, USD } 4.5 \text { million in } 2014 \text { through } \\
2016 \text {, and USD } 7 \text { million each year } \\
\text { thereafter. }\end{array}$ \\
\hline Tennessee & - & $\begin{array}{l}\text { USD } 0.0528 \\
\text { (USD } 0.20 / \text { gal) }\end{array}$ & $\begin{array}{l}\text { Each manufacturer may receive incentives } \\
\text { on up to } 10 \text { million gallons of biodiesel } \\
\text { produced annually. Available through } \\
30 \text { June } 2013 \text {. }\end{array}$ \\
\hline \multirow[t]{2}{*}{ Virginia } & \multirow[t]{2}{*}{$\begin{array}{l}\text { [1] USD 0.0264- } \\
0.033 \\
\text { (USD 0.10- } \\
0.125 / \mathrm{gal})\end{array}$} & $\begin{array}{l}\text { [1] USD } 0.0264-0.033 \\
\text { (USD } 0.10-0.125 / \mathrm{gal} \text { ) }\end{array}$ & $\begin{array}{l}\text { [1] Biofuels Production Grants: Higher rate is } \\
\text { for producers of advanced biofuels. Qualifying } \\
\text { producers must have begun selling neat } \\
\text { biofuels on or after } 1 \text { January } 2008 \text {, or have } \\
\text { expanded production by at least } 1 \text { million } \\
\text { gallons/yr beyond what it produced in } 2007 \text {. } \\
\text { Fuel must be sold in the State. Each produce } \\
\text { is only eligible for six calendar years of } \\
\text { grants. Expires } 30 \text { June } 2017 \text {. }\end{array}$ \\
\hline & & & $\begin{array}{l}\text { [2] Biodiesel Production Tax Credit: Available } \\
\text { for producers who generate up to } 2 \text { million } \\
\text { gallons/yr of biodiesel or green diesel fuel. } \\
\text { The annual credit may not exceed USD } 5000 \text {, } \\
\text { and producers are only eligible for the credit } \\
\text { for the first three years of production. }\end{array}$ \\
\hline
\end{tabular}

Sources:

Canada: Evans and Dessureault (2012); Province of Alberta, Alberta Energy (www.energy.alberta.ca/BioEnergy/pdfs/Guideline_March_2013_Including_3_Yr_Budgets.pdf); Province of Saskatchewan, Ministry of the Economy (www.enterprisesaskatchewan.ca/EthanolGrant and www.enterprisesaskatchewan.ca/RenewableDiesel); Province of Manitoba (http://web2.gov.mb.ca/laws/statutes/ccsm/b040e.php).

United States: US Department of Energy, Alternative Fuels Data Center (www.afdc.energy.gov/laws). 
Annex 2.

\section{Conceptual analysis of the trade effects}

This annex develops a framework for analysis of the trade implications of various types of policies (and combinations of these policies) supporting renewable energy outlining the most important assumptions on characteristics of the markets and policy instruments in question.

\section{Trade in renewable-energy equipment}

Assumptions on the market for renewable energy as well as the market for electricity and the relation between the two are outlined in Box 3.

\section{Box 3. Assumptions on the market for renewable energy and the market for electricity}

It is assumed that the demand for electricity is inelastic (i.e. electricity consumption is unresponsive to the market price) and that the supply of electricity is elastic (i.e. electricity producers produce more electricity when its price increases). The market of electricity is competitive: many suppliers compete with one another and each of them delivers the same product, electricity, but the costs and technologies of producing electricity may differ - that is, each producer has a convex cost function. Another assumption is that both producers and consumers have perfect information about the electricity market.

It is also assumed that electricity producers can produce electricity from either non-renewable (fossilfuel) or renewable energy. The two inputs are (imperfect) substitutes: when given a choice between two units of electricity, one renewable energy and one from fossil energy, the producer has a strict preference for the cheaper unit of electricity (after accounting for differences in reliability and predictability of supply). Since both the costs and technologies differ across producers of electricity, for some of them producing electricity from fossil fuels may be much cheaper than producing electricity from renewable energy, and vice versa. That means that providing incentives for renewable energy does not automatically drive out fossil-fuel energy from the mix of inputs for production, especially as intermittent renewable-energy sources (particularly those driven by sunlight or the wind) are variable in their supply - i.e. they cannot generate power continuously for reasons beyond the direct control of operators, which means that the constant supply of electricity needs to be ensured by access to other energy sources.

An increase in demand for renewable energy in electricity production will lead to at least a proportional rise in demand for renewable-energy equipment; the demand for equipment may be greater if the best sites for renewable-energy harvesting have been developed already. For simplicity of exposition, it is also assumed that there is only one type of energy-equipment that is produced and traded between countries. Since specific renewable-energy technologies, e.g. wind and solar PV, are of tremendously different nature when it comes to their price composition and market structure, a separate analysis of each of these technologies would shed light on differences in the trade impacts depending on which renewable-energy technologies are supported through the incentives in question (see, e.g. Voituriez and Balmer, 2012).

Figure 6 illustrates a stylised market for renewable-energy equipment, linking Country A to the rest of the world (ROW), through supply and demand curves. It is assumed that Country A is a small open economy that is a relatively high-cost producer of renewable- 
energy equipment. ${ }^{89}$ Although it is often difficult to make a clear empirical distinction between a small and a large economy, a theoretical distinction can be drawn. If an economy is "small", it is a "price-taker" of the world market price of, in this case, renewable-energy equipment. In other words, the domestic policies of Country A (Figure 6) have no impact on the world price of imports, which is captured by a horizontal export supply curve $\mathrm{X}$. On the other hand, the domestic policies of Country B, a large open economy, will put pressure on international prices. Hence, in this case the export supply curve is assumed to be upwardsloping, as depicted in Figure 7.

In this analysis, both small- and large-economy scenarios are considered as both can provide insights into the possible effects of policies supporting the renewable-energy sector. The large-economy scenario may be particularly helpful in shedding light on the effects of similar policies adopted by a group of small countries. As such, the export supply curve of the ROW in Figure 6 is a close-up of the one in Figure 7, as depicted in Figure $8 . .^{90}$ In the case of the market for biofuels, for the sake of brevity, only a large-open-economy scenario is considered.

Figure 6. Trade in renewable-energy equipment: Small country
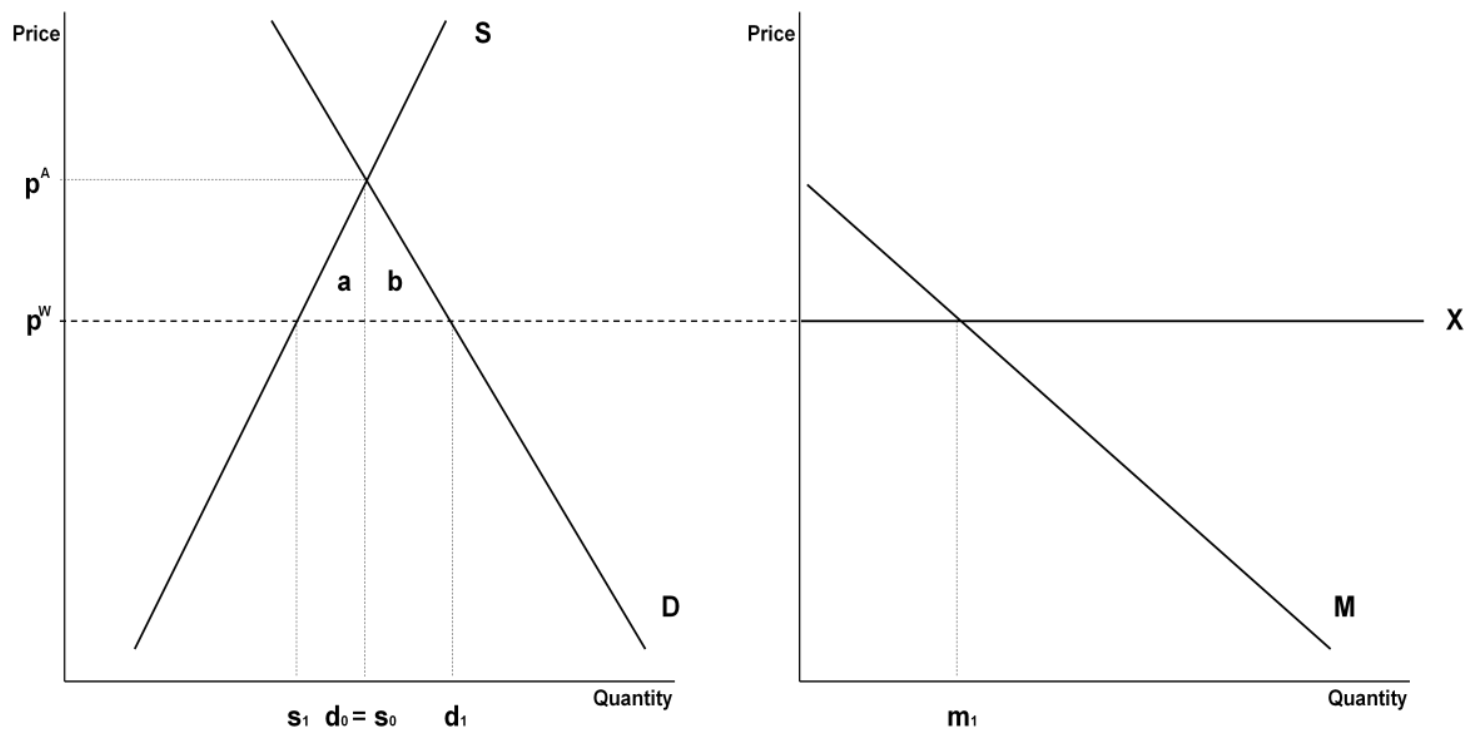

Source: Adapted from Feenstra (2004), p. 217.

89. Country A could as well be a low-cost producer - then its domestic price of renewable-energy equipment would be below the ROW price. As a consequence, Country A would export rather than import - some of its renewable-energy equipment to the ROW.

90. Also, both of these curves, just like almost all the other curves depicted in this analysis, are straight lines, i.e. for the sake of simplicity of graphical representation, a constant slope of most of the supply and demand curves is assumed. 
Figure 7. Trade in renewable-energy equipment: Large country

COUNTRY B

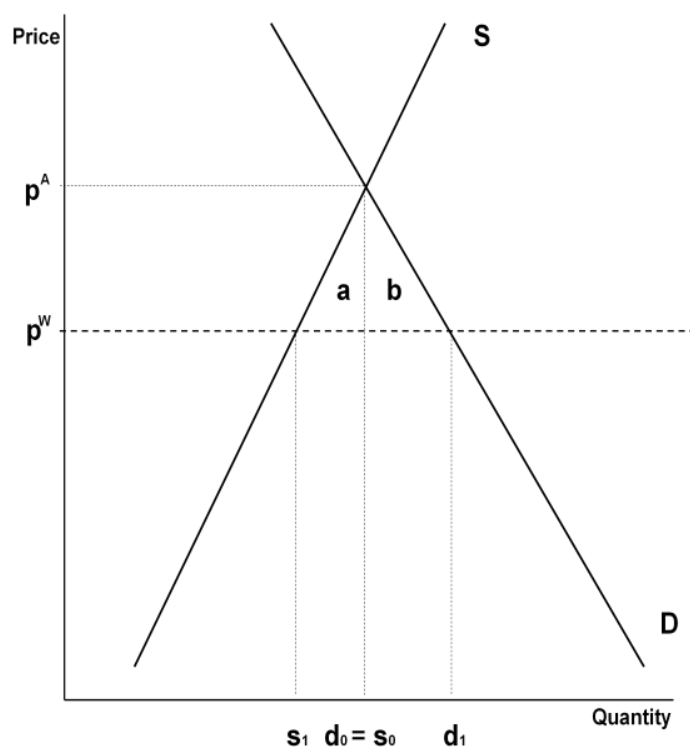

Source: Adapted from Feenstra (2004), p. 219.
REST OF THE WORLD

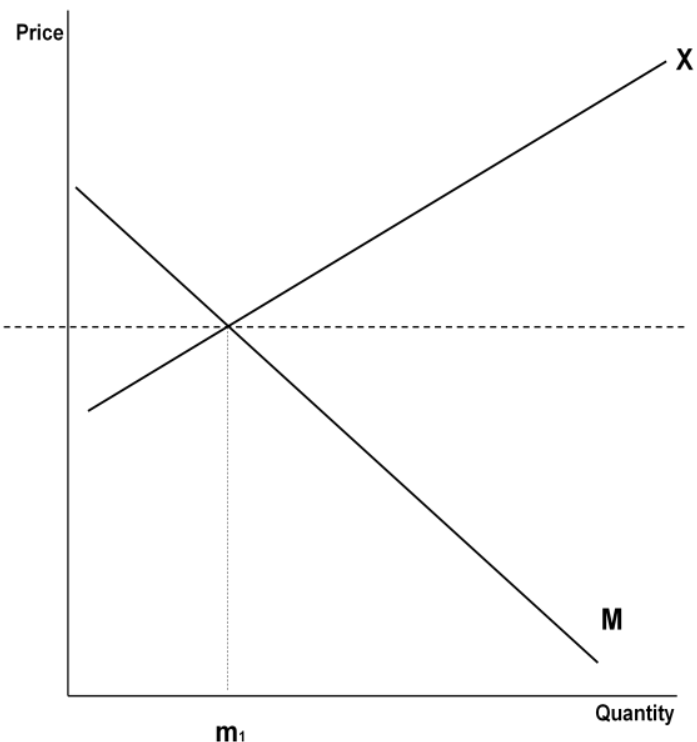

$\mathrm{m}_{1}$

Figure 8. Export supply curve of Country A as a close-up of the export supply curve of Country B

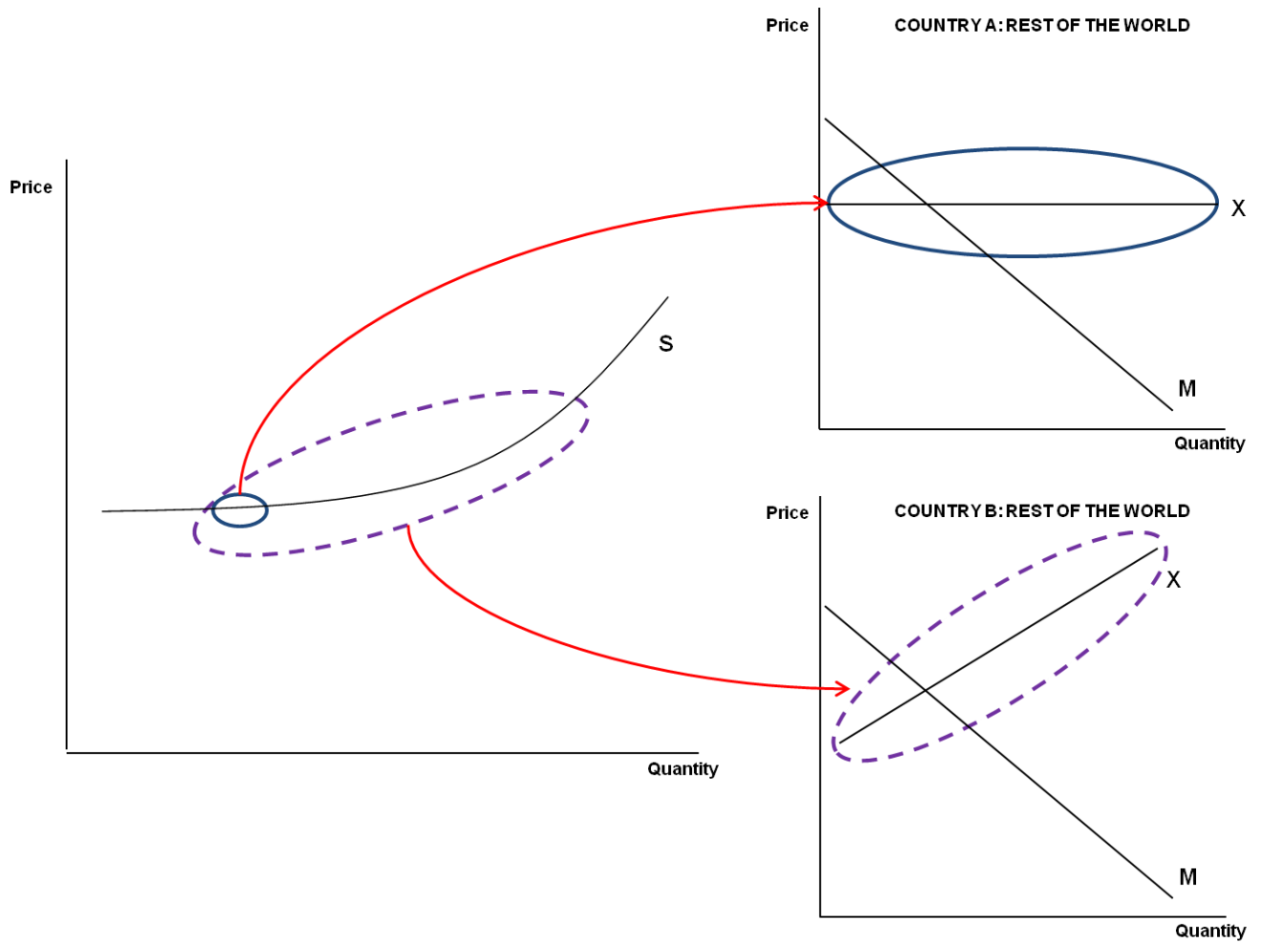


In Figure 6, Country A, in order to satisfy its shortage in supply at the world price, imports renewable-energy equipment from the ROW. The export demand curve (M) is derived from the domestic demand net of the domestic supply (i.e. $\mathrm{M}=\mathrm{D}-\mathrm{S}$ ). ${ }^{91}$ In the absence of trade, the domestic price of renewable-energy equipment in Country A $\left(\mathrm{p}^{\mathrm{A}}\right)$ would be above the price of renewable-energy equipment in the rest of the world $\left(\mathrm{p}^{\mathrm{W}}\right)$. When Country B opens its market to international trade, consumers also turn to cheaper renewableenergy equipment from the ROW (Figure 7). This leads to both an increase in the price of renewable-energy equipment in the ROW and a decrease in the price of renewable-energy equipment in Country $\mathrm{B}$, until prices converge to one global price $\left(\mathrm{p}^{\mathrm{W}}\right)$. In this new equilibrium, Country $\mathrm{B}$ demands $\mathrm{d}_{1}$ of renewable-energy equipment, while its domestic producers are willing to supply only $s_{1}$. The rest of the demand is thus matched by imports from the ROW $\left(\mathrm{m}_{1}=\mathrm{d}_{1}-\mathrm{s}_{1}\right)$. Opening to trade, both by a small and a large economy, leads to gains from trade. In Figures 6 and 7, this additional net consumer surplus is depicted by triangles marked a and $\mathrm{b}^{92}$

The developed model is used to analyse short-run trade impacts on the relevant markets. The long-run impacts of policies supporting renewable-energy sectors are not analysed here, which implies an assumption of no changes in the technologies or in the fixed costs faced by producers.

\section{Market-pull policies for renewable-energy equipment}

Market-pull policies that create market opportunities for renewable-energy technologies can be divided into three broad categories: (1) quota systems, (2) feed-in tariffs (FITs) and premiums, and (3) incentives for deployment. In the following analysis, the trade impacts of each of the three broad categories of market-pull policies on the market for renewable-energy equipment are examined. In general, quota systems, FITs and premiums are financed by electricity consumers, through higher electricity bills. Where funding for that purpose comes from the general budget (e.g. through production tax credits, as in the United States), all taxpayers pay, irrespective of the amount of electricity they consume. The analysis shows that different types of policies could be set at levels that, in the absence of uncertainties, would yield similar trade impacts (Box 4). In addition, Box 5 touches upon the trade impacts of disincentives to non-renewable energy as such policies can also create market opportunities for renewable-energy equipment.

Quota systems are quantity-based mechanisms. A government fixes a minimum share of renewable energy, either in terms of installed capacity or generated electricity. Assuming that this imposed minimum share is higher than what it was before the quota was imposed, the effect of the regulation will be to increase the share of renewable energy in the energy mix, usually at the expense of fossil fuels. That, in turn, drives demand for renewable-energy equipment.

91. In other words, the country presented on the graphs (either A or B) can receive imports from the ROW and the ROW can send its exports only to that country.

92. The focus of this analysis is only on the purely theoretical gains from trade, i.e. the additional consumer and producer surplus from opening to trade. Other gains from trade, for example, would include bigger product variety or quality improvements, which are likely to increase consumer's utility. 


\section{Box 4. Trade effects of feed-in tariffs versus quotas}

It is assumed here that there are no uncertainties in the benefits and in the costs of the analysed policies. All three types of market-pull policies are thus identical in terms of market implications - they all may be "set" to yield the same profits to companies, production quantities, etc. (Hepburn, 2006; Weitzman, 1974). Hence, the analysis of trade implications of these trade policies will be closely similar in terms of their outcomes. A corollary that follows is that a combination of market-pull policies will have the same (but stronger) impact on the market and that the choice of one of these policies, or a combination of them, over the others, should not depend on the outcome of a deterministic model, but should be motivated from an implementation perspective. While the assumption of no uncertainties in the model offers a simplified vision of the market, it suffices for the purpose of a qualitative analysis of the trade implications of a given policy - i.e. its impact on domestic and world-market prices, imports and exports, domestic and world supply and demand.

In reality, different policy instruments (and combinations of these instruments) may have different effects on the demand for renewable-energy equipment. For example, while quotas generate inflexible demand for renewable-based electricity within a certain range, a feed-in premium generates an elastic derived demand curve for renewable-energy equipment.

Moreover, different types of policies have different direct beneficiaries. For example, while incentives for deployment benefit renewable-equipment manufacturers directly, FITs tend to benefit more vertically integrated, independent power producers, and service providers (manufacturers benefit from FITs indirectly, as demand for their products rises with increasing renewable-energy electricity production).

FITs and premiums are price-driven incentives for the production of electricity from renewable-energy sources. ${ }^{93}$ These incentives offer producers a guaranteed price or a premium (on top of the market price for electricity) for each unit of electricity produced from renewable energy fed into the grid and, hence, one can treat them as forms of market price support. ${ }^{94}$ Moreover, since these agreements are usually long-term, they lower investment and capital risks for the producers of electricity from renewable energy. Feed-in tariffs and premiums thus lead to an increase in production of electricity from renewable energy. This increase in consumption of electricity produced from renewable energy leads to, just as in the case of a quota system, an increase in demand for renewable-energy equipment.

Investment incentives for the deployment of renewable-energy technologies ${ }^{95}$ also increase the demand for renewable-energy equipment as they directly make the purchase and installation of renewable-energy equipment cheaper for consumers.

93. Some municipalities, especially those with district-heating systems, also provide higher feed-in tariffs or premiums for heat generated from renewable energy. The following discussion could apply equally to the market for heat. For the sake of brevity, however, only the market for electricity is discussed.

94. A premium implies, by definition, that the price of a unit of electricity or heat produced from renewable energy will be higher than the market price. A guaranteed price can be treated as market price support if, on average, the guaranteed price exceeds the market price (which is the assumption here).

95. Incentives for the deployment of renewable-energy technologies typically take the form of various tax instruments - tax credits, exemptions, reductions, rebates, and variable or accelerated depreciation provisions - and (preferential) loans, loan guarantees and grants. 


\section{Box 5. Disincentives to non-renewable energy as a market-pull policy for renewable energy ${ }^{1}$}

One of the most popular reasons given for implementing both incentives for renewable energy and disincentives to non-renewable (fossil) energy is that both policies address negative production and consumption externalities from using fossil fuels (such as greenhouse-gas emissions and negative health effects). Both incentives for renewable energy and disincentives to fossil energy aim at making renewable (non-polluting) technologies relatively more profitable, which should in turn diminish the share of energy consumption pertaining to fossil fuels.

Figure 9. Impact of disincentives to non-renewable energy on the market for energy

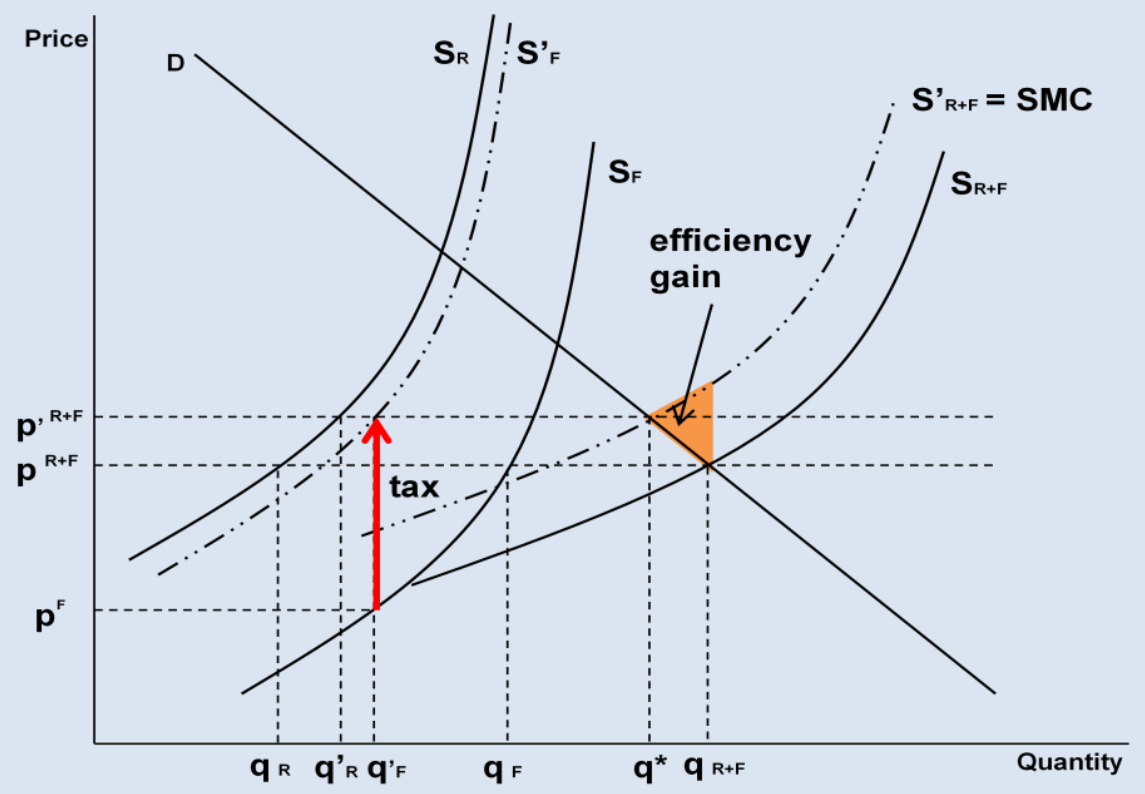

Figure 9 depicts a policy that discourages the use of fossil-energy sources, such as a carbon tax in the electricity market, ${ }^{2}$ which shifts the supply of fossil-fuel energy $\left(\mathrm{S}_{\mathrm{F}}\right)$ to the left as now every unit of fossil-fuel energy is more expensive to use. Consequently, the total supply of energy $\left(\mathrm{S}_{\mathrm{R}+\mathrm{F}}\right)$ on the electricity market also shifts to the left, causing the general price of energy to rise (from $\mathrm{p}^{\mathrm{R}+\mathrm{F}}$ to $\mathrm{p}^{\mathrm{R}+\mathrm{F}}$ ). Due to the tax imposed on carbon, although producers of fossil energy get the price $p^{, R+F}$ for each unit of energy that they sell, they effectively get only $p^{F}$ since they need to subtract the amount of the tax imposed. Hence, taxing the polluting technology can be considered an implicit support to the non-polluting technology as relative profitability of the latter increases. While the renewableenergy supply schedule $\left(S_{R}\right)$ remains unaffected, more renewable energy is consumed (from $q_{G}$ to $q_{G}^{\prime}$ ) as it is assumed here that renewable and non-renewable energy are substitutes in electricity production. ${ }^{96} \mathrm{An}$ increase in demand renewable energy leads to an increase in demand for renewable-energy equipment, i.e. disincentives to non-renewable energy can play a role of demand-pull incentives for renewable-energy equipment.

A tax levied on the use of carbon-based energy sources internalises (fully or partially) the costs of carbon production imposed on others (negative heath impacts of pollution, global warming). The burden of the tax is shared by the energy producers and consumers: it amounts to $\left(p^{R+F}-p^{F}\right) \times q_{F}$ and $\left(p^{, R+F}-p^{R+F}\right) \times q_{F}$ respectively.

The triangle in Figure 9 depicts the efficiency gain associated with taxing carbon. If the efficient level of energy mix is at $\mathrm{q}^{*}$, then imposing the tax leads to an efficient market outcome as the tax imposed raises the private marginal cost of energy production (i.e. the producer's cost of producing energy, which is depicted by the energy supply curve $\mathrm{S}_{\mathrm{R}+\mathrm{F}}$ ) to the social marginal cost of energy production (i.e. the societal cost of energy production, which is equal to the sum of the private cost of energy production and the cost of the negative externality to the consumers and which is represented by the curve SMC).

It is interesting to examine whether a more efficient outcome can also be achieved through the implementation of incentives for renewable energy. Figure 10 depicts the model used in Figure 9, but instead of a tax levied on carbon, a policy incentivising renewable energy is implemented, which shifts the energy supply curve to the right

96.

Although renewable- and fossil-fuel electric-power-generating sources are substitutes, they are imperfect ones — where, as in the case for wind and solar power, output from the renewableenergy-based resource is intermittent (Annex 1). 
(from $S_{R+F}$ to $S_{R+F}^{\prime}$ ). As a consequence, the market equilibrium price decreases (from $p^{R+F}$ to $p^{, R+F}$ ). Consumers benefit while producers of fossil energy lose both from lower prices and lower quantity demanded by the market. The profitability of supplying renewable energy on the other hand increases as now more of it will be produced and the producers will benefit from higher revenues - despite that the market price for energy is now lower, the renewable-energy producers receive support, which implies that for each unit of renewable-energy sold they will receive a higher-than-the-market returns $\left(p^{R}\right)$.

Although the effects of the policy - a simultaneous increase in production of renewable energy and decrease in production of fossil energy - resemble the effects of policies disincentivising non-renewables, the policy has fundamentally different efficiency and fiscal implications. First, the support measure widens the gap between the actual energy consumption and the efficient level of energy consumption (from $q^{*}$ to $q^{\prime}{ }_{R+F}$ ), i.e. the efficiency loss is further increased as depicted by the triangle - the darker part of the triangle is the additional efficiency loss due to the support for renewable energy as it pushes the private marginal cost of electricity production even further away from the social marginal cost (from $S_{R_{+}}$to $S_{R+F}^{\prime}$ ). ${ }^{3}$ Another implication of the policy is its fiscal cost - while taxing carbon may lead to government revenues, support for renewable energy requires government expenditure.

\section{Figure 10. Impact of renewable-energy incentives on the market for energy}

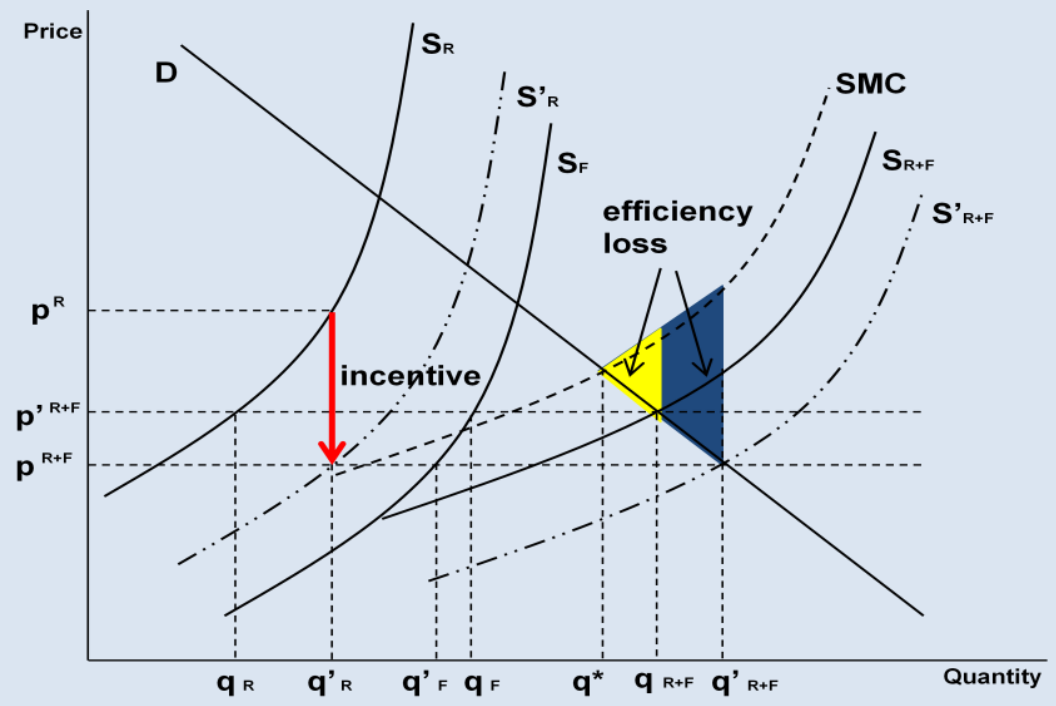

1. Technical terms used in this box are explained in the glossary section of the paper.

2. The effects of other policies disincentivising production or consumption of fossil fuels, such as quotas or price caps, would have the same effects on the market for energy. For the sake of brevity, only a tax on the production of carbon is discussed here.

3. Incentives for renewable energy can, however, lead to positive knowledge and network spillovers. First, investment in renewable-energy research and development contributes to knowledge creation, both home and abroad. Second, installing renewable-energy infrastructure may have beneficial positive network spillovers - for example, once a smart grid is created and solar panels are connected to it, it may become profitable for other electricity producers to connect new solar panels to the network, even if that implies extending the existing network.

The trade impacts of demand-pull measures on the market for renewable-energy equipment are depicted in Figures 11 and 12. In Figure 11 it is again assumed that Country A is a small, relatively high-cost producer of renewable-energy equipment. ${ }^{97}$ The

97. A country implementing market-pull incentives for renewable energy could also be a low-cost producer of renewable-energy equipment. This case is not analysed here, however, as the outcome of the impacts of demand-pull policies on supply and demand, imports and exports in both Country A and the ROW would be similar (except for the fact that the magnitude of the policy impact is very likely to be lower in this case). The crucial difference between the outcomes for countries that produce renewable-energy equipment at high or low cost does emerge when one investigates winners and losers of these policies. 
implementation of a demand-pull policy (or a combination of such policies) by Country A leads to an increase in the domestic demand for renewable-energy-based electricity. The rise in demand for renewable-energy-based electricity in turn drives the demand for renewableenergy equipment - i.e. the derived demand curve for renewable-energy equipment shifts to the right (from D to D'). In the absence of trade, the price would have been pushed to the point where the supply curve $S$ and the demand curve $D^{\prime}$ intersect $\left(p^{\mathrm{A} 1}\right)$. If the ROW can, however, supply renewable-energy equipment at a cheaper price than producers in Country A, trade will offset some or all of the demand pressure on the domestic price. This dynamic drives up the demand for exports from the ROW (from $d_{1}$ to $d_{2}$ ), which consequently drives the exports (from $\mathrm{m}_{1}$ to $\mathrm{m}_{2}$ ).

Figure 11. Impact of demand-pull policies on the market for renewable-energy equipment: Small country

COUNTRY A

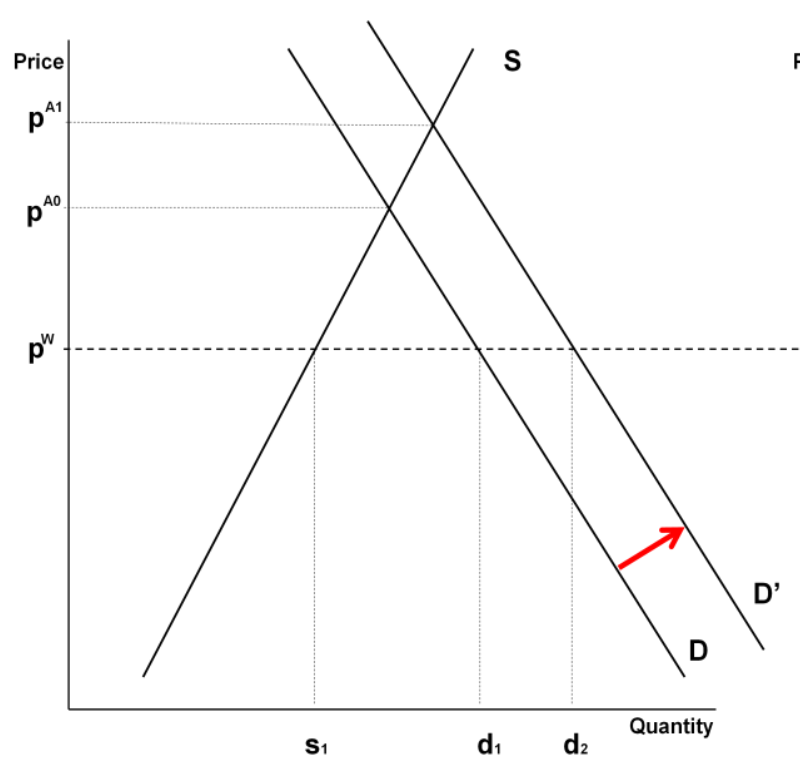

REST OF THE WORLD

Source: Adapted from Feenstra (2004), p. 217.

In Figure 12, it is again assumed that Country B is a large, high-cost producer of renewable-energy equipment. When Country B implements a demand-pull policy, the resulting domestic rise in the demand for renewable-energy equipment, which causes the export curve in the ROW to shift to the right (from M to $M^{\prime}$ ), putting an upward pressure on the price of renewable-energy equipment in the ROW. Once the quantity of exports from the ROW to Country B $\left(\mathrm{m}_{3}\right)$ is equal to the demand for imports from the ROW by the Country B $\left(d_{3}-s_{3}\right)$ the equilibrium price level sets at $\mathrm{p}^{\mathrm{w} 1}$. As a result, exports from the ROW $\left(\mathrm{m}_{3}-\mathrm{m}_{1}\right)$ increase by proportionately less than in the case of a small open economy $\left(\mathrm{m}_{2}-\mathrm{m}_{1}\right)$. Also, total imports from the ROW to Country $B\left(d_{3}-s_{3}\right)$ are increased by proportionately less than in the case of a small country $\left(d_{2}-s_{1}\right)$. This occurs due to the fact that at a higher world price $\left(\mathrm{p}^{\mathrm{W} 1}\right)$, domestic supply of energy equipment increases (from $\mathrm{s}_{1}$ to $\mathrm{s}_{3}$, as at this higher world price more domestic producers can sell their products) and, at the same time, the domestic demand contracts (from $\mathrm{d}_{2}$ to $\mathrm{d}_{3}$ ).

The additional consumer surplus resulting from the policy is proportionately bigger for the domestic consumers from a small country relative to the large-country case. Note that in the case of a small open economy, the domestic consumers benefit from the support by its full 
amount. This is not the case for a large country (Figure 12), as the import price of renewableenergy equipment rises as a result of its increased demand, which implies that domestic and foreign producers are now benefitting from the government policy as well. The distribution of gains between producers in Country B and in the ROW depends on their respective price elasticities of supply and cost structures: the more elastic the supply curve and the lower the production cost for given producers, the bigger their gains from the policy.

Figure 12. Impact of demand-pull policies on the market for renewable-energy equipment: Large country

COUNTRY B

REST OF THE WORLD

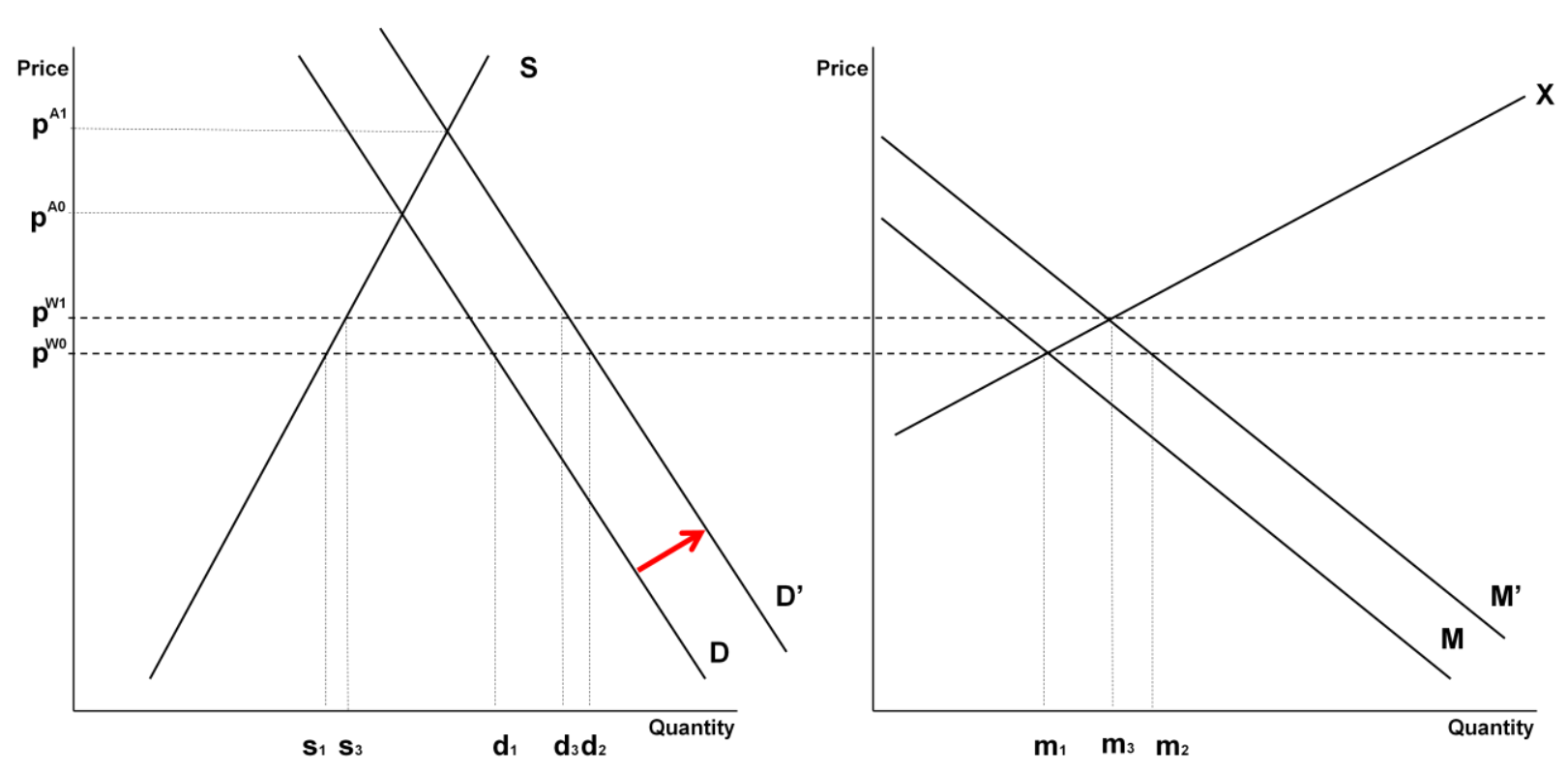

Source: Adapted from Feenstra (2004), p. 219.

\section{Market-pull policies in combination with import tariffs or domestic-content requirements for renewable-energy equipment}

As demonstrated above, market-pull policies usually have a stimulating effect on trade, drawing on imports of renewable-energy equipment to help meet the resulting increase in demand. Implementation of market-pull policies alone maintains equal access for domestic and foreign producers. However, domestic incentives for renewable energy hardly ever comprise demand-pull policies alone, and are often combined with various tariff or non-tariff barriers that can have significant impacts on trade. Two of the most common adjuncts to market-pull policies - import tariffs on renewable-energy equipment and domestic-content requirements ${ }^{98}$ - are analysed in combination with a feed-in tariff in Figures 13 and $14 .^{99}$

98. Another barrier to trade may be created by regulations relating to government procurement that favours domestic producers. Since the trade impacts of such regulation are similar to those of imposing an import tariff, for the sake of brevity this case is excluded from the analysis.

99. The results of the analysis cannot be extended to other demand-pull policies, since the overall effects of combining other demand-pull policies with import tariffs or LCRs may be different than those derived from the analysis presented in Figures 13 and 14. This is due to the fact that other demand-pull policies may have fundamentally different impacts on the domestic renewable-energy-equipment consumption levels (see Box 3). The domestic consumption may 
For simplicity, it is assumed here that the magnitude of the import tariff is equal to the price effect of the FIT. In Figure 13, implementing only the FIT in a small open economy (in the absence of an import tariff) leads to an increase in exports from the ROW to Country A from $\left(\mathrm{m}_{1}=\mathrm{d}_{1}-\mathrm{s}_{1}\right)$ to $\left(\mathrm{m}_{2}=\mathrm{d}_{2}-\mathrm{s}_{1}\right)$. When both the FIT and the import tariff are implemented in combination, the impact of the import tariff more-than-fully offsets the demand incentive for producers from the ROW. Consequently, the level of exports from the ROW to Country A is reduced, not increased (which would be the case if Country A implementing only a demand-pull policy). This outcome is an artifact of the assumption that the price effects of the FIT and the import tariff are of the same magnitude. If the import tariff is of a smaller magnitude than the FIT, then exports from the ROW would fall between $\mathrm{m}_{3}$ and $\mathrm{m}_{2}$.

\section{Figure 13. Impact of a FIT in combination with an import tariff on the market} for renewable-energy equipment: Small country

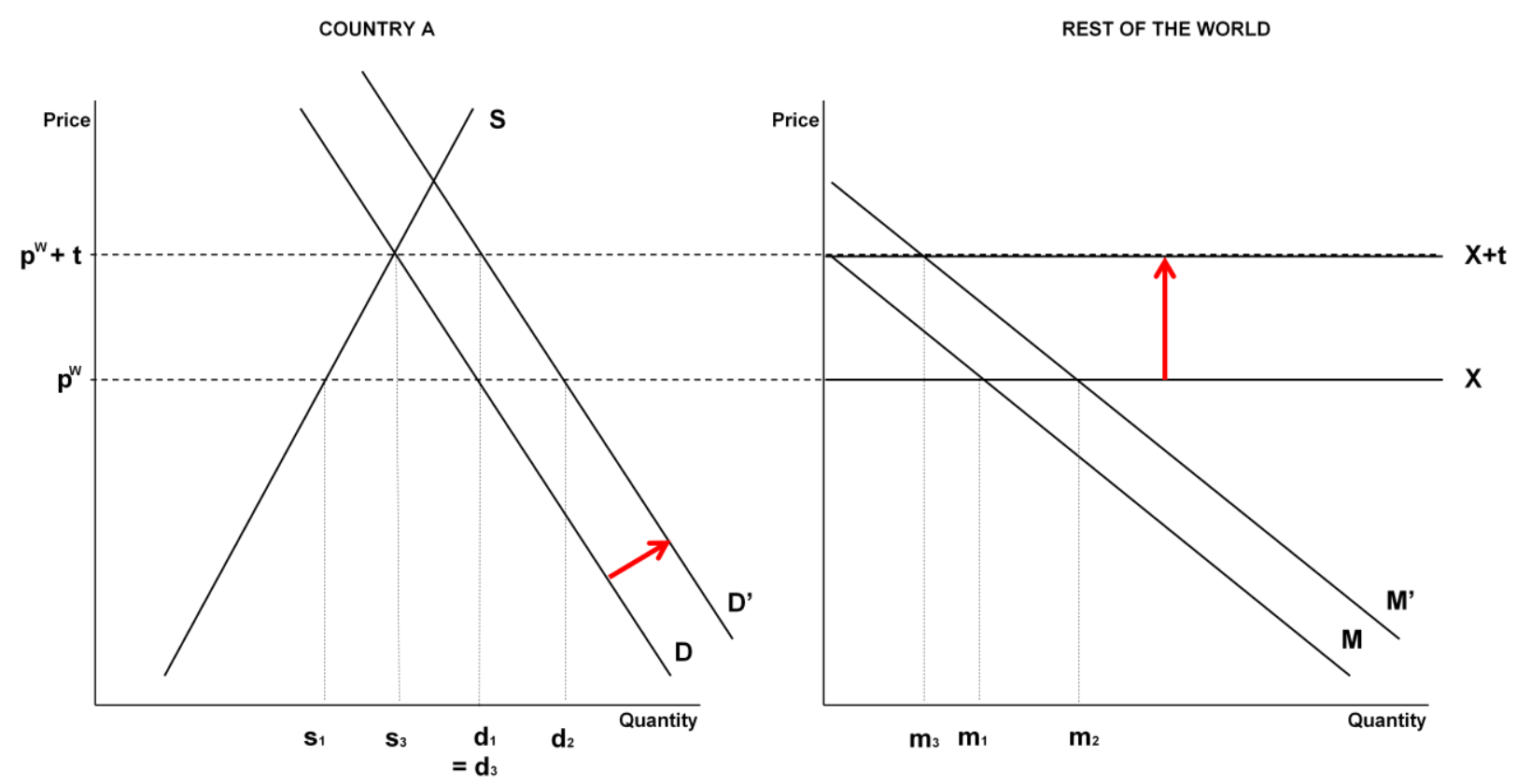

Source: Adapted from Feenstra (2004), p. 217.

Figure 14 presents the effects of a combination of a FIT and an import tariff on a large, previously open economy. The implications of the analysis are exactly the same as the ones for a small country depicted in Figure 12, with one important difference: the price effect drives up the world price of imports to $\mathrm{p}^{\mathrm{w} 1}$, which benefits Country B's domestic producers, but not foreign ones as they will have to give up that rise in the price of their products to be able to sell to the domestic market of Country B, factoring in the cost of a tariff into their business decision. This is illustrated by the fact that the export supply curve shifts upwards not by the full amount of the tariff (to $p^{*}+t$, not $p^{\mathrm{w} 1}+t$ ).

A combination of a FIT and an import tariff benefits both producers in Country B (who can now sell their products at a higher market price) and the government of Country B (as it collects revenues from the import tariff). Electricity ratepayers in Country B are the ones who lose from the policy since now they have to pay more for new RE capacity.

be fixed if the case of a quota and it may even decline in the case of a feed-in premium or a tax credit (if the import tariff is too high). 
Figure 14. Impact of a FIT in combination with an import tariff on the market for renewable-energy equipment: Large country

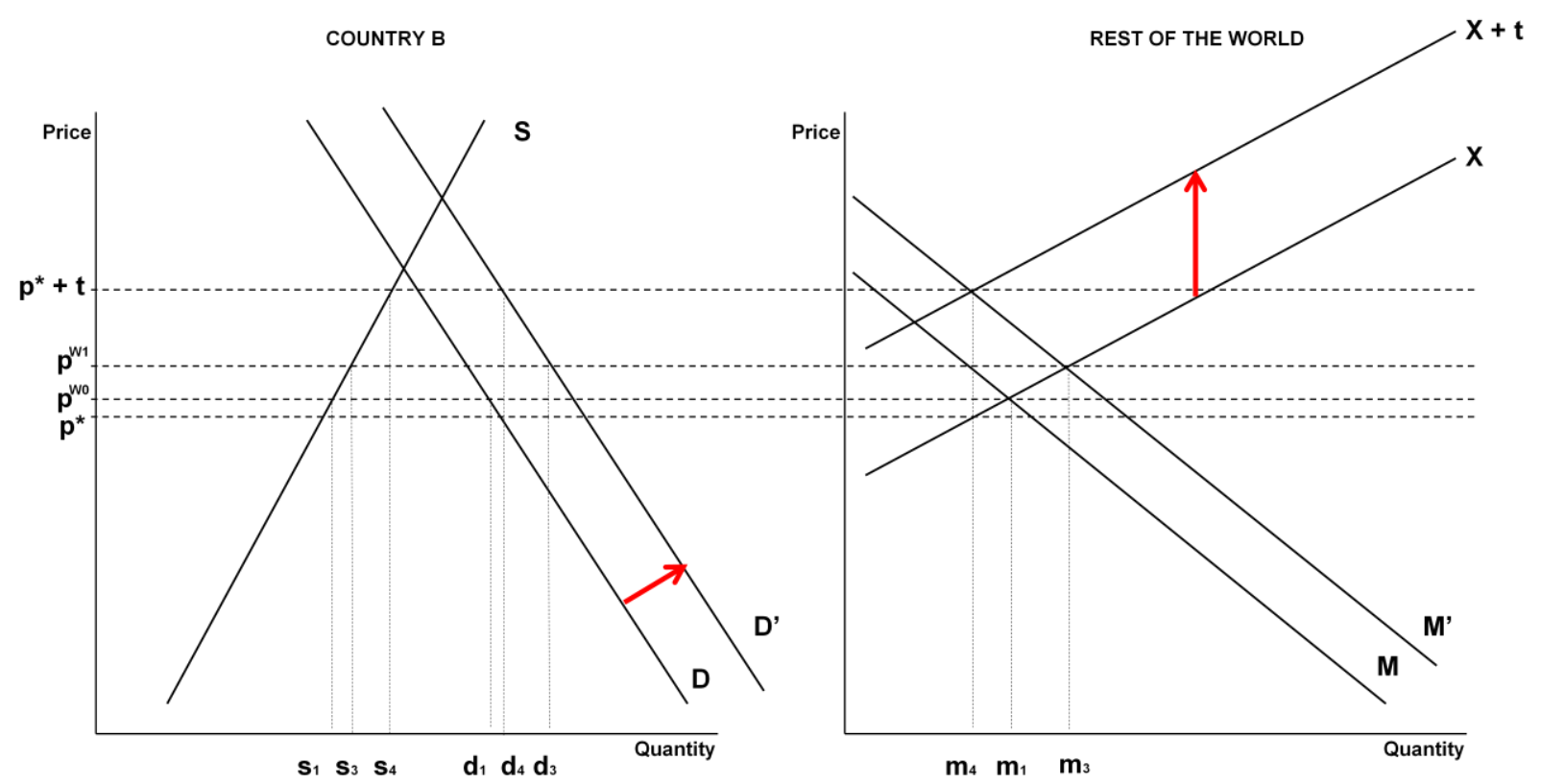

Source: Adapted from Feenstra (2004), p. 219.

Combinations of FITs and domestic-content requirements (DCRs) are likely to have similar trade impacts to the ones described above: DCRs make it difficult (often impossible) for the renewable-energy-equipment producers from abroad to benefit from the domestic demand-pull policies. In this case, however, the government will not collect revenues, which it would from imposing an import tariff. DCRs may take various forms. Often, governments offer feed-in tariffs or feed-in premiums only to those electricity producers that use all, or a specified percentage value of, locally manufactured equipment. DCRs may also be included in renewable-energy tenders and procurements. It is theoretically possible, of course, for an LCR to have little or no effect on trade if it is not binding. For example, it may relate to goods or services that are not internationally traded, which is normally not the case for renewableenergy equipment. Or, the level of the DCR itself may not be binding - i.e. the percentage of local costs that are required to be incurred by a company may be below the percentage of local costs that would be normal when making a decision to invest. ${ }^{100}$

\section{Technology-push incentives for renewable-energy technologies}

Technology-push policies that accelerate the entry of renewable-energy technologies onto the market comprise government support at early and later stages of innovation: at early stages governments focus on providing support for research, development and demonstration (RD\&D), while at later stages they fund programmes supporting product development and manufacturing. The trade impacts of technology-push incentives in a small and large country are examined in Figures 15 and 16 respectively. The results of the analysis are then extended to the trade impacts of support for domestic manufacturing in a large country, followed by a discussion on possible knock-on effects of policies supporting domestic manufacturing (Figure 17).

100. For a more extensive discussion of effects on domestic demand and employment, see Rivers and Wigle, 2011. 
The trade impacts of manufacturing-related incentives for renewable-energy technologies on the market for renewable-energy equipment in Countries A and B are depicted by Figures 15 and 16. It is assumed here that foreign producers of renewable-energy equipment cannot benefit from the support measures offered by Countries A or B as these measures are only granted to those companies that produce domestically. Countries A and B can thus be thought of as developed countries that provide their funding to companies that undertake their manufacturing in the countries pursuing the incentives. ${ }^{101}$ Technology-push policies lead to a reduction in domestic supply costs of renewable-energy equipment, causing a shift of the supply curve of Country A to the right (from $S$ to $S$ '), making production of renewable-energy equipment more competitive. This leads to an increased supply of domestic renewable-energy equipment and, consequently, reduced exports from the ROW $\left(\mathrm{m}_{2}\right)$.

For a large country, however, since domestic policies have an impact on the international price of renewable-energy equipment, an increase in the domestic supply will put a downward pressure on this international price, offsetting to some extent the effect on domestic supply of this incentive (shifting production from $s_{2}$ to $s_{3}$ ) and while increasing domestic demand (from $\mathrm{d}_{1}$ to $\mathrm{d}_{3}$, as cheaper renewable-energy equipment becomes more attractive to the consumer). The net effect could be that proportionately more renewable-energy equipment will be imported from abroad $\left(\mathrm{m}_{3}\right)$ than in the case of a small country $\left(\mathrm{m}_{2}\right)$.

The analysis presented in Figures 15 and 16 ignores knock-on effects on the domestic market in the ROW. Such knock-on effects are likely to be bigger when the technology is easily adaptable abroad and if the supported technology involves a dispersed global supply chain. ${ }^{102}$ Figure 17 presents the trade impacts of incentives for investment in domestic manufacturing capacity for PV modules in a large country. Since the production of PV modules requires assembling components from many other countries, support measures for domestic manufacturing may actually increase imports of these components, which is depicted by a shift of the supply curve of renewable-energy equipment from the ROW from $\mathrm{X}$ to $\mathrm{X}^{\prime}$. These imports will force down the global price of renewable-energy equipment even further than in the case discussed in Figure 16 , from $\mathrm{p}^{\mathrm{W} 1}$ to $\mathrm{p}^{\mathrm{W} 2}$. The global price will decrease the more so the larger the share of Country B's exports in total world trade in the product and the steeper the slope of the demand curve of Country B. The final equilibrium world price for the good will depend on the intersection of the aggregated supply and demand curves of all countries together, after the introduction of the support measure in Country B.

101. Developing or emerging economies, on the other hand, often provide their technology-push policies through offering joint ventures to companies from developed countries.

102. On the other hand, if a technology involves mainly local supply chains (e.g. wind turbines or biofuels), most of the benefits from the support policy will be accrued by domestic producers. 
Figure 15. Impact of manufacturing-related incentives for renewable-energy technologies on the market for renewable-energy equipment: Small country COUNTRY A

REST OF THE WORLD
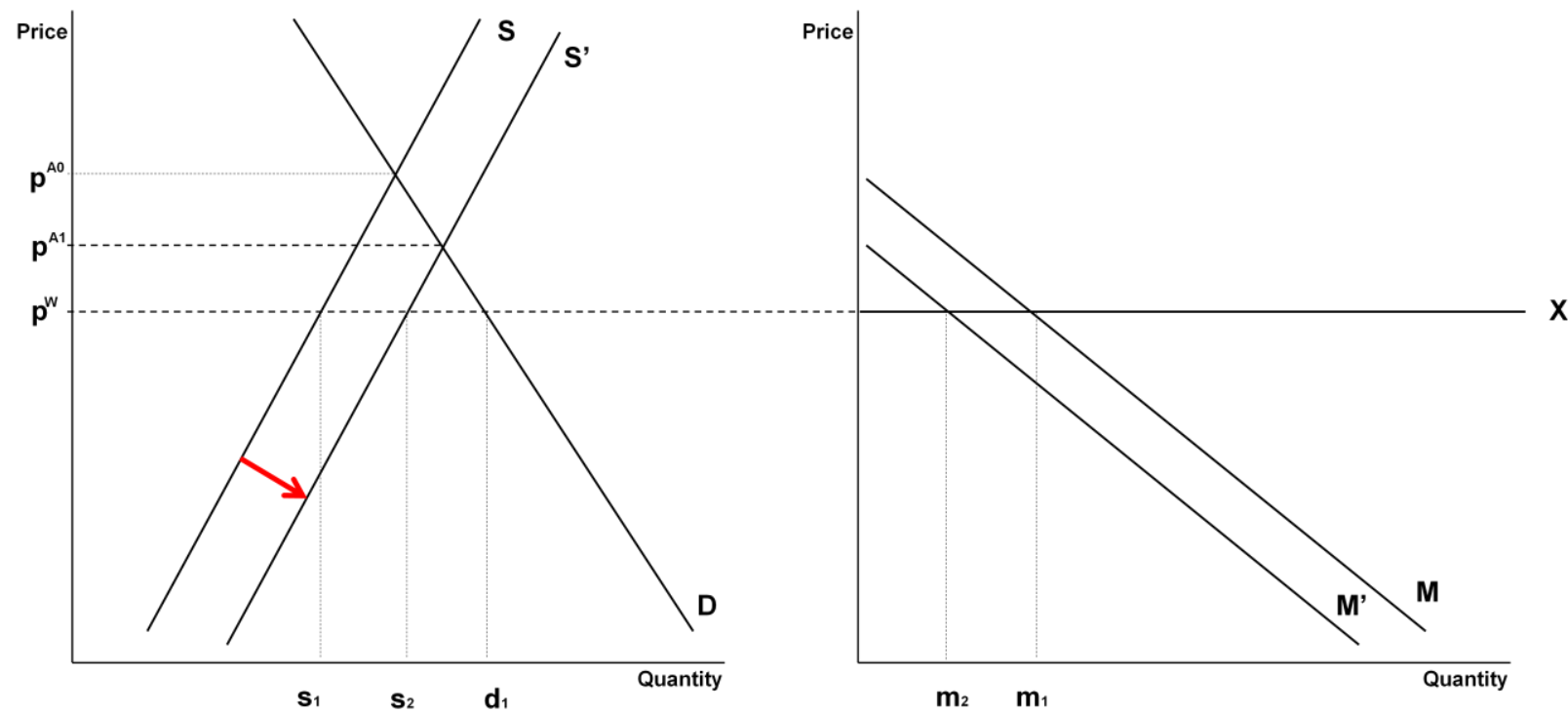

Source: Adapted from Feenstra (2004), p. 217.

Figure 16. Impact of manufacturing-related incentives for renewable-energy technologies on the market for renewable-energy equipment: Large country COUNTRY B REST OF THE WORLD
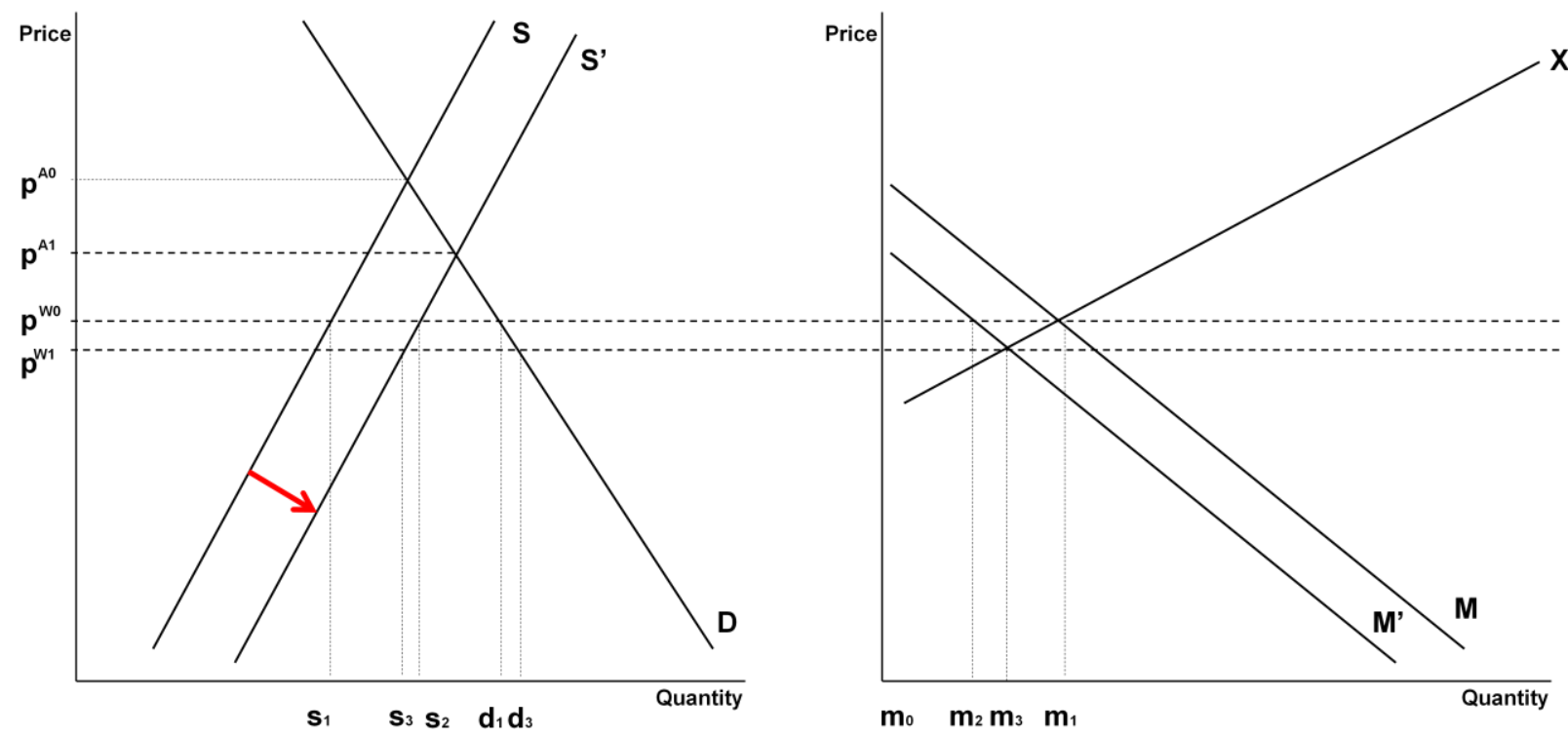

Source: Adapted from Feenstra (2004), p. 219. 
Figure 17. Impact of incentives for investment in domestic manufacturing for PV modules: Large country COUNTRY B REST OF THE WORLD
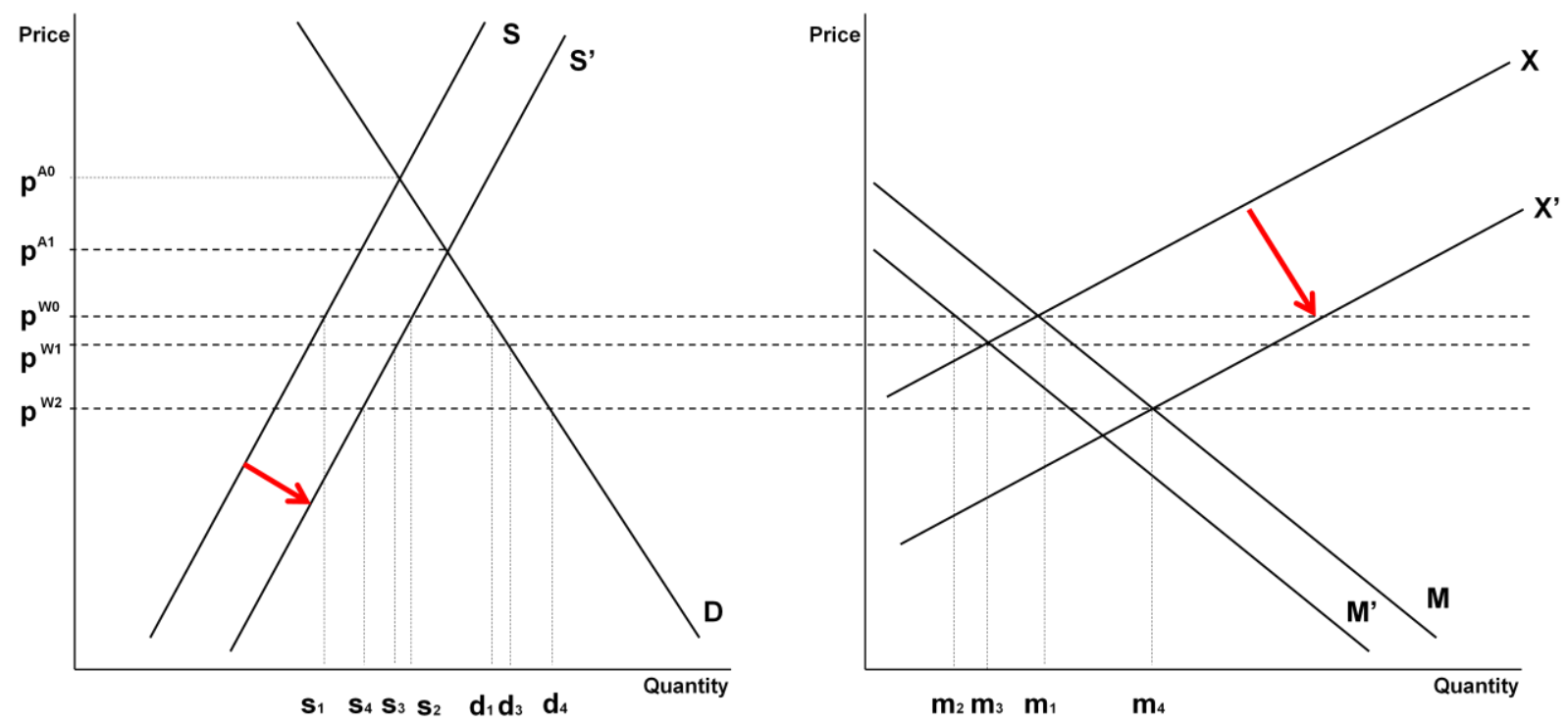

Source: Adapted from Feenstra (2004), p. 219.

\section{Incentives for investment in domestic production of biofuels}

To the extent that the market for biofuels in a given country is similar in its characteristics to the market for renewable-energy equipment, the trade impacts of both demand-pull policies and their combinations with import tariffs will be analogous to those presented for renewableenergy technology in Figures 11, 12, 13 and 14. Also, the trade impacts of investment incentives for domestic production of biofuels are analogous to those of technology-push incentives for the market for renewable-energy technologies (Figures 15 and 16). ${ }^{103}$ However, because the trade effects of investment incentives for domestic production of biofuels are likely to be affected by interactions with other markets, especially the markets for fossil fuels and for crops, incentives for domestic production of biofuels produce knock-on effects.

Figure 18 presents a simplified version of the complex effects of support for production of a biofuels on the market for feedstock crops. ${ }^{104}$ Policies incentivising production of biofuels from crops drive up demand for these crops (from $\mathrm{D}_{\mathrm{BF}}$ to $\mathrm{D}_{\mathrm{BF}}$ ) as more of these crops are needed as inputs to production. A rise in demand puts an upward pressure on the price of crops, driving it from $\mathrm{P}^{\mathrm{CROP}}$ to $\mathrm{P}{ }^{\mathrm{CROP}}$. Now more crops are produced at a higher price. Rising crop prices have various impacts on the economy. The most obvious one is that on food or feed which becomes more expensive. Not only does this apply to consumption of crops (such as sugar, grain or plant oil) but also other food products (such as meat or cereal), since crops

103. Where excise-tax credits for the production of biofuels (which, in most cases, have not discriminated among producers by their country of origin) have been replaced by productionbased payments or tax credits (which are available only to domestic producers), the producers of biofuels from the ROW cannot benefit from these government policies.

104. It is assumed here that the cost of producing a unit of biofuels is higher than the cost of producing a unit of fossil fuels and that biofuels and fossil fuels are perfect substitutes in demand. 
are used as inputs in producing a variety of food products. Moreover, there are domestic (and, to a lesser extent, foreign) producers who face higher prices for the crops used in producing biofuels. In particular, producers of other crops and of livestock (production of which is heavily dependent on grains for supplementing the diet of animals) are very much likely to suffer from higher prices. At some points, rising domestic crop prices may incentivise the producers to import grains that are cheaper than domestic feedstock.

Figure 18. Impact of incentives for production of biofuels on the market for feedstock crops

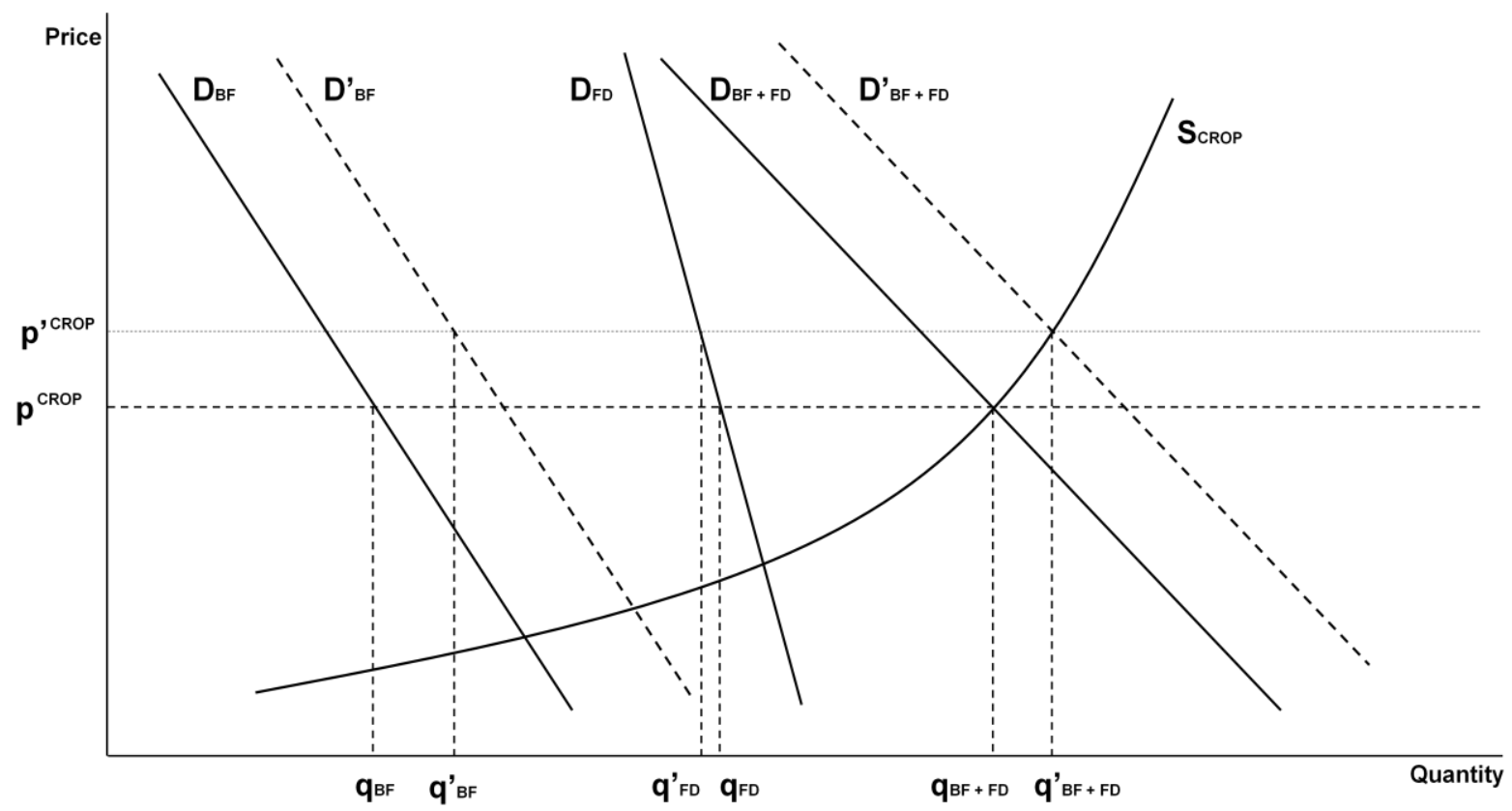

\section{Long-term impacts of policies supporting renewable energy}

The foregoing analysis focuses only on the short-run effects of policies. Understanding the long-run effects, however, is crucial for a thorough understanding of the trade effects of policies supporting the renewable-energy sector. There are a few very important factors that the short-run analysis does not take into consideration. First, increased openness of the markets incentivises companies to cut their costs and improve their products. Second, the level of technology is not fixed and technological development in the renewable-energy sector may arise as a byproduct of discoveries pursued in other sectors of the economy. In other words, in reality the supply curves of firms are not fixed, but constantly changing. For example, Figure 19 depicts the price-experience curve for PV modules in Europe, which shows that, over the last 20 years, PV modules have experienced an impressive price reduction (EPIA, 2011). ${ }^{105}$ Finally, offering support for manufacturing of renewable-energy technologies may, in the long-run, distort the functioning of the market for the renewableenergy technologies, leading to various inefficiencies and distortions compared with the optimal allocation of investment. For example, government support measures have made investments in the PV-module manufacturing more attractive than in the absence of such policies, which may have driven investors away from the optimal allocation of their investments elsewhere.

105. On average, their price fell by $20 \%$ with every doubling in the cumulative volume sold. This $20 \%$ is sometimes referred to as "the learning factor". The average price of a PV module in Europe reached around EUR 1.2/W in 2011, which in real terms is about $70 \%$ lower than it was in 2001. 
Figure 19. PV-module price experience curve

100

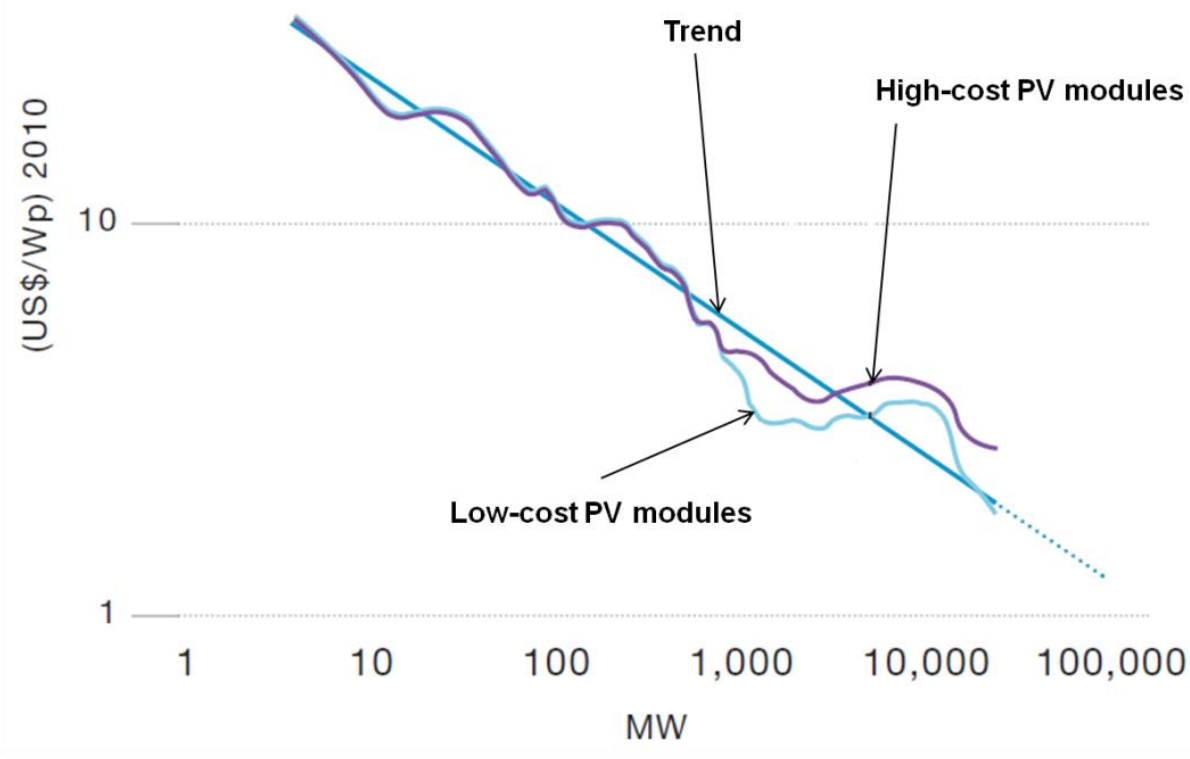

G1

Notes: Prices are expressed in 2010 USD.

Source: Adapted from EPIA (2011), p. 14.

In light of the above example of government support for a particular technology (here using PV modules an example) a question emerges: Is technology-neutral support more welfare enhancing than technology-specific support? On the one hand, since market failures tend to vary by technology (as different technologies present different market failures and, at any given time are likely to vary in their stages of development), there is rationale for introducing some technology-specific support measures to address specific market failures (Fischer et al., 2008). On the other hand, technology-specific policies risk dividing the market into "losers" and "winners", which may create intra-market investment, production and consumption distortions. Support for a specific technology may also lead to a technological "lock in"; that is to say, supporting a given technology may create a critical investment mass for a given technology that may prevent investors from being interested in other, more efficient technologies.

While more research is needed to answer these questions, some important insights into this issue have been offered by Carolyn Fischer, Richard Newell and Louis Preonas (Fischer and Newell, 2008; Fischer and Preonas, 2010; Fischer et al., 2012). One of their findings is that, if the policy objective is to address market failures, the justifiable levels of support are likely to be much smaller than those currently provided. In particular, even if very high rates of knowledge spillovers from learning-by-doing are assumed, ambitious renewable-energy portfolio standards seem unlikely to be welfare enhancing. Given that "getting the prices right" on emissions would raise electricity prices and efficiently improve the competitiveness of renewable-energy technologies relative to the fossil technologies, large additional subsidies for renewable energy might not be necessary. Even for "next generation" technologies like advanced solar energy, with larger potential for cost reductions, the optimal subsidies in support of learning-by-doing would, according to their analysis, be smaller than generally 
offered. Correcting R\&D market failures, on the other hand, has a much larger potential for reducing the costs of achieving significant emissions reductions.

\section{Long-term impacts of policies supporting biofuels}

As for policies supporting biofuels, possible long-term effects include those on the value of immobile assets (notably farmland and biofuels refineries) and on the development of transport technologies. Owners of farmland and those investing in production of biofuels will be primary beneficiaries of policies supporting biofuels, to the extent these policies generate economic rents. Since owners of farmland will charge more for leasing their lands, other farmers will have to pay more for renting land. Also, buyers of such land (or feedstock) will pay a higher price for it. ${ }^{106}$ Moreover, as it is realistic to assume that biofuels will tend to be consumed with petroleum fuels by the transport sector, this will tend to reinforce the current transport technology which is based on internal-combustion-engine dominated transport and it could, as a consequence, discourage the emergence of alternative transport modes and technologies (Barg et al., 2007).

106. The price will be increased by the discounted stream of future subsidy-boosted profits. 


\section{References}

ADEME (2011), FOGIME, Fonds de Garantie des Investissements de Maîtrise de l'Energie, Agence de l'Environnement et de la Maîtrise de l'Energie,

www.ademe.fr/entreprises/Aides/documents/fogime_note.pdf.

Adnan, Hanim (2013), "B10 mandate to address biodiesel woes?” The Star Online, 23 February 2013, available at http://biz.thestar.com.my/news/story.asp?file=/2013/2/23/business/12742691\&sec=business

Agencia EFE (2011), “Spain’s Iberdrola Big Winner of Brazil Wind Auction”, Latin American Herald Tribune, http://laht.com/article.asp?CategoryId=14090\&ArticleId=364474.

Almada, Miguel (2008), "National program for biofuels", in Dorothea Garff and Nicolás Corrent (eds.), Argentina: Key Player in the Biofuels Market, German-Argentinian Chamber of Industry and Commerce, Buenos Aires.

ARPA-E (2013), Advanced Research Projects Agency, http://arpa-e.energy.gov, accessed 24 June 2013.

Australia Parliament (2011), Taxation of Alternative Fuels Legislation Amendment Bill 2011 Ethanol Production Grants Bill 2011 - Excise Tariff Amendment (Taxation of Alternative Fuels) Bill 2011 - Customs Tariff Amendment (Taxation of Alternative Fuels) Bill 2011: Exposure Draft Explanatory Memorandum, Canberra.

Australian Government, An Overview of the Clean Energy Legislative Package, www.cleanenergyfuture.gov.au/clean-energy-future/an-overview-of-the-clean-energylegislative-package/.

Barg, Stephan, Aaron Cosbey and Ronald Steenblik (2007), “A Sustainable Development Framework for Assessing the Benefits of Subsidy Reform”, pp. 31-60, in: Subsidy Reform and Sustainable Development: Political Economy Aspects, OECD, Paris 2007.

Bonvillian, William and Charles Weiss (2009), Structuring an Energy Technology Revolution, The MIT Press, Cambridge, Massachusetts.

Barros, Sergio (2012), “Brazil biofuels: Annual Report 2012”, GAIN Report No. BR12013, US Foreign Agricultural Service, Washington, D.C.

Boscoe, Adam (2010), "Uruguay - wind: Government issues tender for 150 MW of new capacity", Renewable Energy Latin America, 6 May 2010. Accessed at http://latamrenewables.com/2010/05/06/uruguay-wind-government-issues-tender-for-150-mwof-new-capacity/.

Bradsher, Keith (2012), "Strategy of solar dominance now poses a threat to China", New York Times, 5 October 2012, p. B1. Published on-line as "Glut of solar panels poses a new threat to China”, www.nytimes.com/2012/10/05/business/global/glut-of-solar-panels-is-a-new-test-forchina.html?pagewanted=all\&_r=0.

Brazil, Ministério da Fazenda (2012), "2013 Programade Sustentaçãodo Investimento — R\$ 100 bilhões" ["The 2013 Investment Support Programme"], Ministério da Fazenda, Brasília, Brazil.

Buijs, Bram (2012), China and the Future of New Energy Technologies: Trends in Global Competition and Innovation, Clingendael International Energy Programme, The Hague, Netherlands. 
Castano, Ivan (2011), "Wind could become Brazil's second power generation source in 2015", Renewable Energy World, 22 November 2011. www.renewableenergyworld.com/rea/news/article/2011/11/wind-could-become-brazilssecond-power-generation-source-in-2015, accessed 29 November 2011.

Cenex (2011), Alternative Fuels Infrastructure Grant Programme: Summary of Projects Supported, Cenex, Leicester, UK.

CFDA (2013), Catalogue of Federal Domestic Assistance, www.cfda.gov/?s=program\&mode=form\&tab=step $1 \& \mathrm{id}=$ aafeb43a25034b93ce8e1c842d6fcb3, accessed 24 June 2013.

Churchill, Susannah (2013), "Why is net metering under attack?”, GreentechSolar, 15 January 2013, available on-line at www.greentechmedia.com/articles/read/why-is-net-metering-underattack.

Clean Energy Legislative Package, Department of Climate Change and Energy Efficiency, Australian Government, www.climatechange.gov.au/en/government/submissions/clean-energylegislative-package.aspx.

Connor, Peter (2004), National Innovation, Industry Policy and Renewable Energy Technology, British Institute of Energy Economics, St John's College, Oxford.

Croce, Raffaele Della, Christopher Kaminker, Fiona Stewart (2011), The Role of Pension Funds in Financing Green Growth Initiatives. OECD Working Papers on Finance, Insurance and Private Pensions, No. 10, OECD Publishing, Paris, http://dx.doi.org/10.1787/5kg58j1lwdjd-en.

DEA (2011), Renewable Energies Export Initiative, Deutsche Energie Agentur GmbH, www.dena.de/en/topics/renewable-energies/projects/projekt/renewable-energies-exportinitiative or www.exportinitiative.de, accessed 12 October 2011.

Dessureault, Darlene (2011), Canada Biofuels Annual: 2011, GAIN Report Number CA11036, US Department of Agriculture, Foreign Agricultural Service, Washington, D.C., http://gain.fas.usda.gov/Recent\%20GAIN\%20Publications/Biofuels\%20Annual_Ottawa_Cana da_07-05-2011.pdf

DIF (2011), Danish Investment Fund, www.ens.dk/en-us/Sider/forside.aspx, accessed 21 November 2011.

Directive 2009/29/EC of the European Parliament and of the Council of 23 April 2009 amending Directive 2003/87/EC so as to improve and extend the greenhouse gas emission allowance trading scheme of the Community (Text with EEA relevance), Paragraphs 19 and 23, EUR-Lex, http://eur-lex.europa.eu/LexUriServ/LexUriServ.do?uri=CELEX:32009L0029:EN:NOT.

DOE (2013a), Database of State Incentives for Renewables and Heat, www.dsireusa.org/, accessed 24 June 2013.

DOE (2013b), SunShot Initiative, Department of Energy, www1.eere.energy.gov/solar/sunshot, accessed 24 June 2013.

EC (2005), Strengths, Weaknesses, Opportunities and Threats in Energy Research, European Commission, DG Research, Office for Official Publications of the European Communities, Luxembourg, http://ec.europa.eu/research/energy/pdf/swot_en.pdf.

ECOFYS (2011), Financing Renewable Energy in the European Market by order of European Commission, DG Energy.

EIA (2010), International Energy Outlook 2010, US Energy Information Administration, Washington, D.C.

EIT (2011), European Institute of Innovation and Technology, http://eit.europa.eu/, accessed 15 November 2011. 
EPIA (2011), "Solar photovoltaics competing in the energy sector: On the road to competitiveness", European Photovotaic Industry Association, Brussels, www.epia.org.

European Commission (2010), Emissions Trading Scheme (EU ETS), European Commission, 15 November 2010, http://ec.europa.eu/clima/policies/ets/index_en.htm .

EUREC (2011), European Renewable Energy Research Centres Agency, www.eurec.be/, accessed 15 November 2011.

Evans, Brent and Darlene Dessureault (2012), “Canada biofuels annual - 2012 revised”, Gain Report No. CA120127, 20 July 2012, US Department of Agriculture, Foreign Agricultural Service, Washington, D.C., http://gain.fas.usda.gov/Recent\%20GAIN\%20Publications/BIOFUELS\%20ANNUAL_Ottawa _Canada_07-20-2012.pdf .

Feenstra, Robert C. (2004), Advanced International Trade: Theory and Evidence, Princeton University Press, New Jersey.

Fischer, Carolyn and Richard Newell (2008), "Environmental and Technology Policies for Climate Mitigation”, Journal of Environmental Economics and Management, 55(2): 142-62.

Fischer, Carolyn and Louis Preonas (2010), "Combining Policies for Renewable Energy: Is the Whole Less Than the Sum of Its Parts?" International Review of Environmental and Resource Economics, 4(1): 52-92.

Fischer, Carolyn, Richard Newell and Louis Preonas (2012), "Environmental and Technology Policy Options in the Electricity Sector: Interactions and Outcomes", http://www.feem.it/getpage.aspx?id=4891\&sez=Events\&padre=82.

Flach, Bob, Karin Bendz and Sabine Lieberz (2012), "EU biofuels annual — 2012”, GAIN Report No. NL2020, US Foreign Agricultural Service, Washington, D.C.

Fraunhofer (2011), Fraunhofer-Gesellschaft, www.fraunhofer.de/en/.html, accessed 15 November 2011.

Grau, Thilo, Molin Huo and Karsten Neuhoff (2011), Survey of Photovoltaic Industry and Policy in Germany and China, CPI Report, Climate Policy Initiative, DIW Berlin and Tsinghua University, www.climatepolicyinitiative.org/files/attachments/112.pdf.

Gray, Robin (2012), "Canada biofuels annual: 2012 — revised”, GAIN Report No. CA120127, US Foreign Agricultural Service, Washington, D.C. He, Laura (2012), "China's government to the rescue as Solar Crisis Deepens". Forbes, 31 October 2012.

Haley, Usha C.V. and George T. Haley (2013), Subsidies to Chinese Industry: State Capitalism, Business Strategy, and Trade Policy, Oxford University Press, Oxford, UK.

Helmholtz Association (2011), Helmholtz Association of National Research Centres, www.helmholtz.de/en/, accessed 21 November 2011.

Hepburn, Cameron (2006), "Regulation by prices, quantities, or both: A review of instrument choice", Oxford Review of Economic Policy, Vol. 22, No. 2, pp. 226-247.

ICD - Munich (2011), Innovation Centre Denmark - Munich, www.icdmuenchen.um.dk/, accessed 21 November 2011.

International Center for Trade and Sustainable Development (ICTSD) (2011), China to End Challenged Subsidies in Wind Power Case, 13 June 2011, http://ictsd.org/i/news/biores/108435/.

IEA (2010), Energy Technology Perspectives 2010, IEA Publications, Paris.

IEA (2012), Renewables Information, IEA Publications, Paris.

IEA (2013), Renewable Energy Policy Database, www.iea.org/textbase/pm/?mode=re. 
Iijima, Midori (2011), Japan Biofuels Annual: 2011, GAIN Report, US Department of Agriculture, Foreign Agricultural Service, Washington, DC, http://gain.fas.usda.gov/Recent\%20GAIN\%20Publications/BIOFUELS\%20ANNUAL_Tokyo_ Japan_6-30-2011.pdf.

IPCC (2011a), Special Report on Renewable Energy Resources and Climate Change Mitigation: Policy, Financing and Implementation, Chapter 1, http://srren.ipcc-wg3.de/.

IPCC (2011b), Special Report on Renewable Energy Resources and Climate Change Mitigation: Policy, Financing and Implementation, Chapter 11, http://srren.ipcc-wg3.de/.

Japan to support Five Domestic Consortia with Subsidies/Diplomacy to fight Chinese Solar Energy Competition in Asia and Africa, Green World Investor, 4 July 2011, www.greenworldinvestor.com/2011/07/04/japan-to-support-five-domestic-consortia-withsubsidiesdiplomacy-to-fight-chinese-solar-energy-competition-in-asia-and-africa/

Jong Henry W. de and William G, Shepherd, eds. (2007), Pioneers of Industrial Organization: How the Economics of Competition and Monopoly Took Shape, Edward Elgar, Cheltenham.

Joseph, Ken (2012), “Argentina: Biofuels Annual - 2012”, GAIN Report, US Foreign Agricultural Service, Washington, D.C.

Josling, Tim, David Blandford and Jane Earley (2010), "Biofuel and biomass subsidies in the US, EU and Brazil: Towards a transparent system of notification", IPC Position Paper, September 2010, International Food and Trade Policy Council, Washington, D.C.

Jung, Anna, Philipp Dörrenberg, Anna Rauch and Michael Thöne (2010), Biofuels - At What Cost? Government support for ethanol and biodiesel in the European Union-2010 Update, Global Subsidies Initiative of the International Institute for Sustainable Development, Geneva, Switzerland, www.globalsubsidies.org/files/assets/bf_eunion_2010update.pdf.

Kamp, Linda., Ruud E.H.M. Smits and Cornelis D. Andriesse (2004), "Notions on learning applied to wind turbines development in the Netherlands and Denmark", Energy Policy 32, pp. 1625-1637.

Kaminker, C., O. Kawanishi, F. Stewart, B. Caldecott and N. Howarth (2013 forthcoming), Institutional Investors and Green Investments: Healthy Scepticism or Missed Opportunity?, OECD Publishing, Paris.

Krome, Margaret, Teresa Maurer and Katie Wied (2009, October), Building Sustainable Farms, Ranches and Communities: Federal Programs for Sustainable Agriculture, Forestry, Entrepreneurship, Conservation and Community Development, US Department of Agriculture in collaboration with the Michael Fields Agricultural Institute and the National Center for Appropriate Technology (NCAT), Washington, DC., https://attra.ncat.org/guide/Building_Sustainable.pdf.

Kutas, Géraldine, Carina Lindberg and Ronald Steenblik (2007), Biofuels - At What Cost? Government support for ethanol and biodiesel in the European Union, Global Subsidies Initiative of the International Institute for Sustainable Development, Geneva, Switzerland,

Lacey, Stephen (2011), “How China dominates solar power," The Guardian, 12 September 2011, www.guardian.co.uk/environment/2011/sep/12/how-china-dominates-solar-power.

Landrin, Sophie and Pierre Le Hir (2012), « Coup d'arrêt au solaire dans les régions françaises », Le Monde, 3 December 2012, http://abonnes.lemonde.fr/planete/article/2012/12/03/coup-darret-au-solaire-dans-les-regions-francaises_1799049_3244.html.

Lane, Jim (2011), "Biofuel mandates around the world", Biofuels Digest, 21 July 2011, http://biofuelsdigest.com/bdigest/2011/07/21/biofuels-mandates-around-the-world/.

Lane, Jim (2012), "Biofuel mandates around the world", Biofuels Digest, 22 November 2012, www.biofuelsdigest.com/bdigest/2012/11/22/biofuels-mandates-around-the-world-2012/. 
Markley, Brooke (2012), "Biodiesel Tax Increase and Temporary Soybean Import Policy”, GAIN Report, US Foreign Agricultural Service, Washington, D.C.

Maurer, Luiz T.A. and Luiz A. Barroso (2011), Electricity Auctions: An Overview of Efficient Practices, World Bank, Washington, DC.

McKenna, Cameron, Olexander Martinenko, Vitaliy Radchenko and Volodymyr Kolvakh (2012), "Ukraine: procedure for calculating local content for feed-in tariffs adopted", CMS Cameron McKenna, 9 November 2012, www.lexology.com/library/detail.aspx?g=d5abfd3d-085c-44278587-357ed1c38ef7.

Maniatis, Kyriakos, Michael Weitz and Alexander Zschocke, eds. (2011, June), 2 million tons per year: A performing biofuels supply chain for EU aviation, European Commission, Brussels, http://ec.europa.eu/energy/renewables/biofuels/doc/20110622_biofuels_flight_path_technical_ paper.pdf.

Ministry of Production and Work of Cordoba Province (2008), "Cordoba is the pioneer in research and development of biofuel”, in Dorothea Garff and Nicolás Corrent (eds.), Argentina: Key Player in the Biofuels Market, German-Argentinian Chamber of Industry and Commerce, Buenos Aires, pp. 37-38.

Ministry of Science (2012), Ministry of Science and Technology of the Peoples' Republic of China, www.most.gov.cn/eng/programmes1/, accessed 24 May 2012.

Moïsé, Evdokia and Ronald Steenblik (2011), Trade-Related Measures Based on Processes and Production Methods in the Context of Climate-Change Mitigation, OECD Trade and Environment Working Papers, 2011/04, OECD Publishing, Paris, http://dx.doi.org/10.1787/5kg6xssz26jg-en.

Natcore (2010), Natcore Signs Agreement with Chinese Consortium to Take its Solar Technology From Lab to Power Grid, Natcore News Releases, 22 February 2010, www.natcoresolar.com/index.php?option=com_content\&view=article\&id=74\&Itemid=75, accessed 25 May 2012.

Natcore (2010b), New Jersey Solar Pioneer Finalizes Chinese Deal Aimed at Making Solar Energy Cost-Competitive, Natcore News Releases, 18 August 2010, www.natcoresolar.com/index.php?option=com_content \&view=article\&id=69\&Itemid=75, accessed 25 May 2012.

NEDO (2012a), About NEDO, New Energy and Industrial Technology Development Organization, www.nedo.go.jp/english/introducing_profile.html, accessed 25 May 2012.

NEDO (2012b), News List (2012, New Energy and Industrial Technology Development Organization, www.nedo.go.jp/english/archives2012_index.html, accessed 25 May 2012.NEI (2010), Renewable Energy and Energy Efficiency Export Initiative. TPCC Working Group on Renewable Energy and Energy Efficiency, National Export Initiative, Trade Promotion Coordination Committee, Washington D.C.

NEI: National Export Initiative (2011), Renewable Energy and Energy Efficiency Export Initiative, TPCC Working Group on Renewable Energy and Energy Efficiency, Washington, DC.

Nelson, Richard R., David C. Mowery and Jan Fagerberg (2006), The Oxford Handbook of Innovation, Oxford Handbooks Online, Oxford.

Nielsen, Stephan (2013), "Brazil wind companies may boost prices $20 \%$ to comply with rules", Bloomberg, 27 February 2013, available at www.bloomberg.com/news/2013-02-27/brazilwind-companies-may-boost-prices-20-to-comply-with-rules.html.

OECD (1998), Improving the Environment through Reducing Subsidies: Part I: Summary and Conclusions - Part II: Analysis and Overview of Studies, OECD Publishing, Paris. doi: 10.1787/9789264162679-en. 
OECD (2009), Declaration on Green Growth, Meeting of the Council at Ministerial Level, 24-

25 June, C/MIN(2009)5/ADD1/FINAL, www.oecd.org/dataoecd/58/34/44077822.pdf.

OECD (2010), Public Research Institutions: Mapping Sector Trends, OECD Publishing, Paris.

OECD (2011), Arrangement on Officially Supported Export Credits, www.oecd.org/department/0,3355,en_2649_34171_1_1_1_1_1,00.html, accessed 21 November 2011.

PICS (2010), Local Content Requirements in British Columbia's Wind Power Industry: Case Studies, University of Victoria, Canada.

Preechajarn, Sakchai and Ponnarong Prasertsri (2012), “Thailand: Biofuels Annual — 2012”, GAIN Report No. TH2064, US Foreign Agricultural Service, Washington, D.C.

PV Magazine (2013), "Photovoltaic feed-in-tariffs-for-various-countries", available on-line at www.greentechmedia.com/articles/read/why-is-net-metering-under-attack.

Quilter, James (2011), “Ontario slashes Samsung subsidy by 75\%”, Windpower Monthly, 4 August 2011.

Quintas, Paul and Ken Guy (1995), "Collaborative, pre-competitive R\&D and the firm", Research Policy 24 (1995), pp. 325-348.

Reiche, Danyel (2010), "Sovereign wealth funds as a new instrument of climate protection policy? A case study of Norway as a pioneer of ethical guidelines for investment policy”, Energy 35(9), pp. 3569-3577.

REN21 (2011), Renewables 2011 Global Status Report, Renewable Energy Policy Network for the $21^{\text {st }}$ Century. REN 21 Secretariat, Paris. www.ren21.net/REN21Activities/Publications/GlobalStatusReport/tabid/5434/Default.aspx.

Rivers, Nic and Randy Wigle (2011), "Domestic content requirements and renewable energy legislation", University of Ottawa Working Paper, electronic copy available at http://ssrn.com/abstract=2129808

Robins, Nick, Robert Clover and Charanjit Singh (2009), A Climate for Recovery: The colour of stimulus goes green, HSBC Bank plc, London, www.globaldashboard.org/wpcontent/uploads/2009/HSBC_Green_New_Deal.pdf.

Sapp, Meghan (2012), "Spain opens up biodiesel market but Argentina still mad", Biodiesel Digest, 23 October 2012. Accessed at www.biofuelsdigest.com/bdigest/2012/10/23/spainopens-up-biodiesel-market-but-argentina-still-mad/.

Schmookler, Jacob (1966), Invention and Economic Growth, Harvard University Press, Cambridge Massachusetts.

Schumpeter, Joseph A. (1934 [1982]), Theory of Economic Development: An Inquiry into Profits, Capital, Credit, Interest, and the Business Cycle, Harvard University Press, Cambridge Massachusetts.

Skidmore, Mark, Chad Cotti and James Alm (2011), The Political Economy of State Government Subsidy Adoption: The Case of Ethanol, Michigan State University, Michigan, USA, http://mpra.ub.uni-muenchen.de/33937/1/MPRA_paper_33937.pdf.

SoloPower (2011), SoloPower receives offer of conditional commitment for a \$197 million loan guarantee from US DOE to build thin film photovoltaic module factory, 17 February 2011 , www.solopower.com/solopower-receives-loan-to-build-film-photovoltaic-factory.html.

Solyndra (2011), Solyndra Offered \$535 Million Loan Guarantee by the US Department of Energy, 20 March 2009, www.solyndra.com/2009/03/us-department/.

Springboard Biodiesel (2011), Biodiesel mandates and initiatives, Chico, California, USA, www.springboardbiodiesel.com/biodiesel-big-mandates-Initiatives-global. 
Tawney, Letha, Francisco Almendra, Pablo Torres and Lutz Weischer (2011, September), “Two Degrees of Innovation-How to seize the opportunities in low-carbon power", WRI Working Paper, World Resources Institute, Washington DC. Available online at www.wri.org.

Timmins, Thomas J. and Leslie Blumer (2013), “Canada: Ontario's Minister of Energy Announces Changes to Feed-In Tariff Program”, Growlings (Gowling Lafleur Henderson LLP), 18 June 2013.

www.mondaq.com/canada/x/245550/Renewables/Ontarios+Minister+Of+Energy+Announces+ Changes+To+FeedIn+Tariff+Program.

UNEP (2010), United Nations Environment Programme Report, Global Trends in Sustainable Energy Investment 2010: Analysis of Trends and Issues in the Financing of Renewable Energy and Energy Efficiency, www.rona.unep.org/documents/news/GlobalTrendsInSustainableEnergyInvestment2010_en_fu 11.pdf

UNEP (2011), Global Trends in Renewable Energy Investment 2011: Analysis of Trends and Issues in the Financing of Renewable Energy. United Nations Environment Programme, Paris, http://bnef.com/Download/UserFiles_File_WhitePapers/sefi_unep_global_trends_2010.pdf.

United States and Korea: Joint financing initiative for trade and investment in "green" products, Global Trade Alert, 31 October 2011, www.globaltradealert.org/measure/united-states-andkorea-joint-financing-initiative-trade-and-investment-green-products.

US Environmental Protection Agency, Acid Rain Program $\mathrm{SO}_{2}$ Allowances Fact Sheet, www.epa.gov/airmarkets/trading/factsheet.html.

USDOE/AFDC (2013), US Department of Energy, Alternative Fuels \& Advanced Vehicles Data Center, Federal \& State Incentives and Laws, www.afdc.energy.gov/afdc/laws/matrix/tech .

USEIA (2012), Electric Power Annual, US Energy Information Administration, Washington, DC.

Valente, Marcela (2010), “Argentina's agrofuels start their engines”, Tierramérica, 15 February 2010. Accessed at www.censat.org/articulos/10030-noticia/804-Argentinas-Agrofuels-StartTheir-Engines.

Voituriez, Tancrède and Bettina Balmer (2012), "The Muddle over Green Race", Studies No. 01/12, IDDRI, Paris, France.

Weitzman, Martin L. (1974), "Prices vs. quantities", Review of Economic Studies, Vol. 41, No. 4, pp. 477-491.

Wisner, Robert (2011), Proposed biofuel mandates for 2012 and the blend wall, AgMRC Renewable Energy \& Climate Change Newsletter, July 2011, Iowa State University, Ames, Iowa, USA, www.agmrc.org/renewable_energy/biofuelsbiorefining_general/proposed_biofuel_mandates_f or_2012_and_the_blend_wall.cfm.

Wisner, Robert (2013), Biofuels Mandates Outside the US, AgMRC Renewable Energy \& Climate Change Newsletter, February 2013, Iowa State University, Ames, Iowa, USA, http://www.agmrc.org/renewable_energy/biofuelsbiorefining_general/biofuels-mandatesoutside-the-us/

WTO: World Trade Organization (2011), "New and Full Notification Pursuant to Article XVI:1 of the GATT 1994 and Article 25 of the Agreement on Subsidies and Countervailing Measures: United States", Document Symbol G/SCM/N/220/USA, 19 October 2011, Geneva.

Yulisman, Linda (2013), "RI sees bright outlook for palm oil exports", The Jakarta Post, 9 January 2013, p. 3. 


\section{GLOSSARY}

Accelerated depreciation - A provision in a country's tax code that allows businesses to allocate the costs of past expenditures on fixed assets over a shorter accounting period than using straight-line depreciation.

Applied tariff - The actual import tariff applied by a country on a particular good imported from a particular trading partner, or partners, at any given moment.

Biodiesel - A diesel-equivalent, processed fuel made from the esterification (a chemical process which removes the glycerine from the oil) of both vegetable oils and animal fats.

Biofuels - Generally liquid fuels derived from biomass or waste feedstocks and include ethanol, biodiesel, and bio-jet.

Biogas - A mixture of primarily methane and $\mathrm{CO}_{2}$ produced by the bacterial degradation of organic matter and used as a fuel.

Bound tariff - The maximum most-favoured nation import tariff on a particular good that a member economy of the World Trade Organization commits to applying.

Complements - Goods that are consumed in combination. For example, shoe laces are complements of shoes and jam is a complement of bread. Perfect complements are goods that are always consumed in combination: the consumer will always consume the same ratio of each good - for example, a left shoe is almost always a complement of the right shoe from the same pair of shoes.

Consumer surplus - The benefit derived by consumers from consuming a good above and beyond the price they paid for consuming the good.

Demand curve - A curve showing the quantity of a good demanded within a given market at each price.

Denatured ethyl alcohol - ethyl alcohol (ethanol) to which chemicals have been added to prevent human consumption. Denatured ethyl alcohol is generally only used as a fuel or for industrial purposes.

Domestic-content requirement - A legal requirement or practice compelling firms to purchase a certain percentage of their inputs from domestic providers of goods or services as a precondition for local market access or preferential policy treatment, such as a subsidy or tax break.

Economic profit - In economic theory, the term "economic profit" (also "abnormal profit", "pure profit", "super normal profit" or "excess profit") refers to the difference between a firm's revenue and total costs (including the opportunity cost of a venture to the investors).

Efficiency gain (efficiency loss) - In microeconomic theory, the market for a given good is efficient if there is no shortage of supply or demand in that market, i.e. the price in that market is set where the marginal cost of producing a good and the marginal benefit of consuming a good are equal (under the assumption of no market failures). Such a situation is called "efficient" as it maximises consumer and producer surplus. Any change in the market leading to increasing producer or consumer surplus (or both) leads to an efficiency gain and vice versa. 
Ethanol - Ethyl alcohol that is normally produced from fermenting any biomass high in carbohydrates (starches and sugars) or cellulose and hemicelluloses (the fibrous material that makes up the bulk of most plant matter) using advanced techniques.

Excise tax - A special tax levied on a specific kind of good, typically alcoholic beverages, tobacco and fuels; it may be imposed at any stage of production or distribution and is usually assessed by reference to the weight or strength or quantity of the product.

Fossil fuel - A fuel derived from the remains of ancient plant and animal life. Fossil fuels include peat, lignite, bituminous and sub-bituminous coal, petroleum (derived from conventional geological formations, oil sands or oil shale), and natural gas (derived from conventional geological formations, coal seams, natural-gas shales, or methane clathrate).

Gas-to-liquids - A process featuring reaction of methane with oxygen or steam to produce syngas followed by synthesis of liquid products (such as diesel and naphtha) from the syngas using FischerTropsch catalytic synthesis. The process is similar to those used in coal-to-liquids or biomass-toliquids.

Green Bond - A government-guaranteed bond invested in a large-scale renewable energy project that reduces carbon emissions.

Heat energy - Heat is obtained from fuel combustion, nuclear reactors, geothermal reservoirs, capture of sunlight, exothermic chemical processes and heat pumps which can extract it from ambient air and liquids. It may be used for heating or cooling or converted into mechanical energy for transport vehicles or electricity generation.

Hydro-electric power - Kinetic energy of water converted into electricity in hydroelectric plants. It excludes output from pumped storage and marine (tide and wave) plants.

International aviation bunkers - Deliveries of aviation fuels to aircraft for international aviation. Fuels used by airlines for their road vehicles are excluded. The domestic-international split is determined on the basis of departure and landing locations and not by the nationality of the airline.

Levelised cost of energy - A method of comparing the long-run cost of energy across different technologies. It represents the net present value of the total, annualised cost of building and operating an electricity-generating plant or other energy facility over its economic life.

Local-content requirement - Another term used for domestic-content requirement.

Low-carbon technology - A technology that produces zero or small amounts of greenhouse-gas emissions during its operation. In the power sector this category includes fossil-fuel-fired plants fitted with carbon capture and storage equipment, nuclear power plants and renewable-energy-based generating technologies.

Marginal cost - The incremental cost to a firm of producing one more unit of a good. See private marginal cost and social marginal cost.

Negative externality - A negative externality occurs whenever an individual's consumption or a firm's production reduces the well-being of others who are not compensated by that individual or by that firm. An example of negative externalities relevant to this paper are carbon and other GHG emissions. In the absence of government intervention, those parties that emit carbon and other GHGs usually do not compensate society for the fact that they contribute to the climate change (globally) and to adverse health effects (in the neighbourhood of where emissions take place).

Nuclear energy — The electricity or process heat produced by a nuclear power plant.

Opportunity cost - The forgone opportunity of the next best alternative use of money spent on some purpose, e.g. to subsidise a good or service.

Private marginal cost - The direct cost to producers of producing an additional unit of a good. 
Producer surplus - The benefit derived by producers from selling a good above and beyond the cost of producing that good.

Social marginal cost - The private marginal cost to producers of producing a good plus any costs associated with the production of the good that are imposed on others. Social marginal cost is equal to the private marginal cost in the absence of externalities.

Substitutes (perfect substitutes, imperfect substitutes) - Goods are substitutes if consuming one good will reduce consumption of the other - for example, a piece of cake and a bar of chocolate. Goods are perfect substitutes if consuming one good replaces the consumption of the other good for example, a unit of electricity produced from renewable energy and a unit of electricity produced from fossil energy. In this case, the consumer is indifferent between the goods and will always choose the one that is cheaper on the market.

Supply curve - A curve showing the quantity of a good that firms are willing to supply at each price.

Undenatured ethyl alcohol - pure ethyl alcohol (ethanol). Undenatured ethyl alcohol can be used as fuel, as an input in production of pharmaceuticals and chemicals, or as a fortifier of alcoholic beverages.

Welfare-enhancing policy - A policy that increases the total surplus (a sum of consumer surplus and producer surplus) in a given market.

\section{Sources}

Gruber, Jonathan (2007), Public Finance and Public Policy, $2^{\text {nd }}$ edition, Worth Publishers, New York.

IEA on-line glossary, Available at: www.iea.org/aboutus/glossary/e /.

OECD on-line glossary, Available at: stats.oecd.org/glossary/index.htm.

Varian, Hal R. (2003), Intermediate Economics: A Modern Approach, $6^{\text {th }}$ edition, W. W. Norton \& Company, New York. 